\title{
Abastecimento de Madeira para a ProduÇão de Celulose: UMA APLICAÇÃo da ECONOMIa dOS CuSTOS DE TRANSAÇÃo
}

\section{Ana RaQuel Bueno Moraes Ribeiro}

Engenheiro Agrônomo

Orientador: Prof. Dr. LuIz Carlos Estraviz Rodriguez

Dissertação apresentada à Escola Superior de Agricultura "Luiz de Queiroz", Universidade de São Paulo, para obtençāo do título de Mestre em Ciências, Área de Concentração: Economia Aplicada. 
Dados Internacionais de Catalogação na Publicação (CIP) DIVISĀO DE BIBLIOTECA E DOCUMENTAÇĀO - Campus "Luiz de Queiroz"/USP

Ribeiro, Ana Raquel Bueno Moraes

Abastecimento de madeira para a produção de celulose: uma aplicação da economia dos custos de transaçāo / Ana Raquel Bueno Moraes Ribeiro. - - Piracicaba, 1998.

$117 \mathrm{p}$.

Dissertaçāo (mestrado) - Escola Superior de Agricultura Luiz de Queiroz, 1998. Bibliografia.

1. Agribusiness 2. Celulose de eucalipto 3. Economia florestal 4. Incentivo fiscal 5. Industria agricola 6 . Industria de papel e celulose 7 . Terceirização 8 . Verticalização I. Título 
PARA BRENO. COM TODA ADMIR.AÇÃO E CARINHO. 
“...MIL VEZES A EXPERIENCIA TEM DEMONSTRADO, MESMO EM PESSOAS NÃO PARTICULARMENTE DADAS Ȧ REFLEXÃO, QUE A MELHOR MANEIR.A DE CHEGAR A LMA BOA DĖIA É IR DENANDO DISCORRER O PENSAMENTO AO SABOR DOS SEUS PROPRIOS ACASOS E RCLRAÇÕES, MAS VIGIANDO-O COM UMA ATENÇÃO QUE CONVEM PARECER DISTRAIDA, COMO SE SE ESTIVESSE A PENSAR NOUTRA COISA, E DE REPENTE S.ALTA-SE EM CMA DO DESPREVINIDO ACHADO COMO UM TIGRE SOBRE A PRESA..." JOSÉ S.ARAMAGO 
Concluir um trabalho traz sempre uma sensação gratificante. Igual sentimento pode ser vivido ao se escreverem os agradecimentos... Este é o momento de lembrar-se de tudo de positivo que aconteceu para o trabalho ir crescendo. crescendo até ter forma e consistência de trabalho terminado.

Aqui está, enfim terminado... Muito obrigada a todos vocês!

Ao grande amigo e orientador Luiz Carlos Estraviz Rodriguez;

Ao professor Décio Zylbersztajn;

À Cia. Suzano de Papel e Celulose;

Ao Departamento de Economia e Sociologia Rural da ESALQ;

À minha, sempre presente, família. 


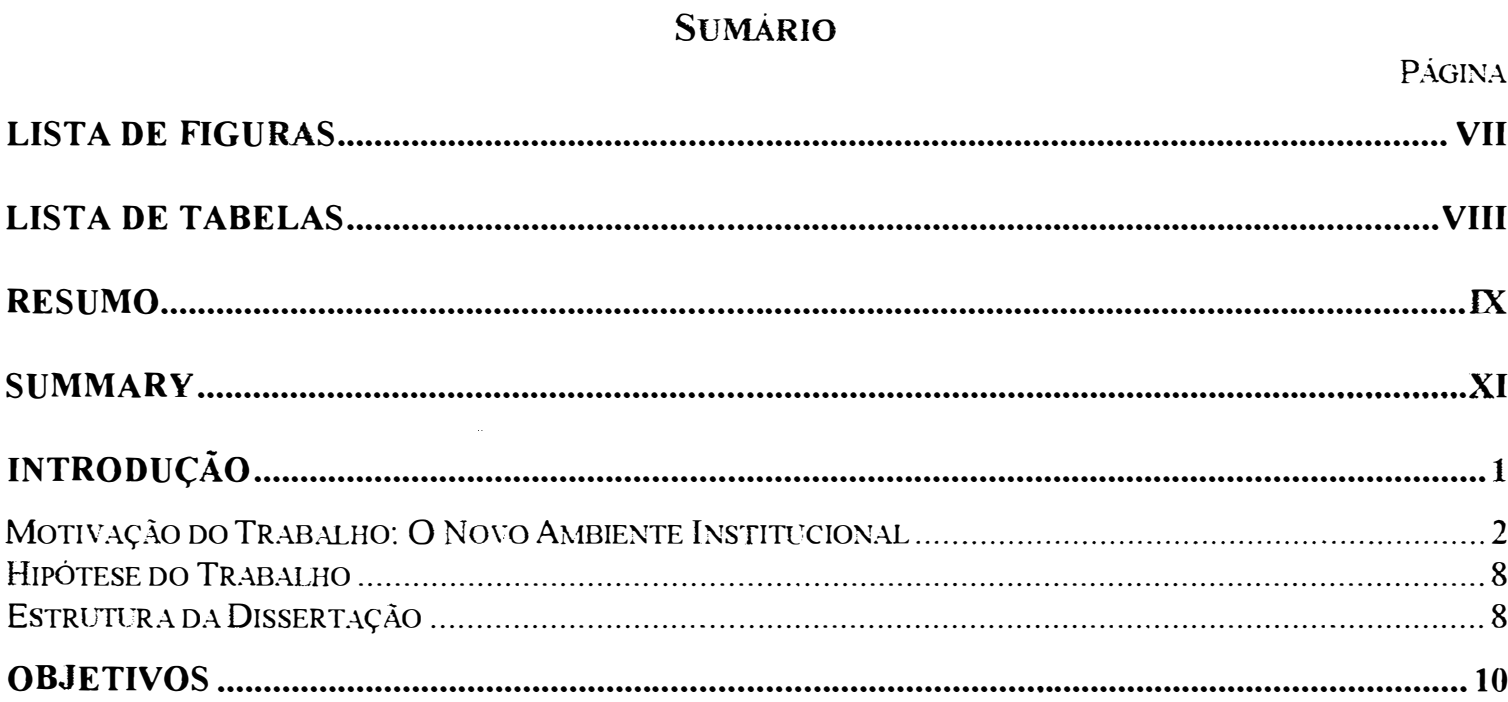

1. O SISTEMA AGROINDUSTRIAL DA CELULOSE NO BRASIL ............................................ 11

2 REFERENCIAL TEÓRICO: A ECONOMIA DOS CUSTOS DE TRANSAÇÃO..........................31

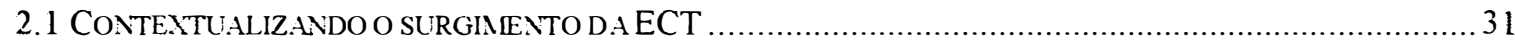

2.2 CoNCEITOS FUNDAIENTAIS DA ECONOMIA DOS CUSTOS DE TRANSAÇÃO.........................................4

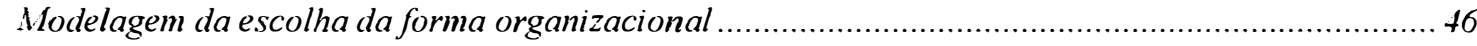

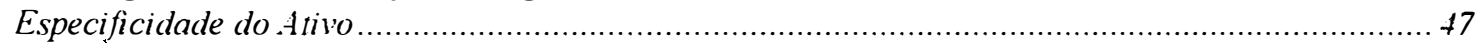

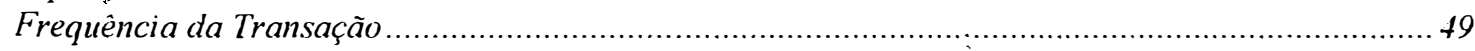

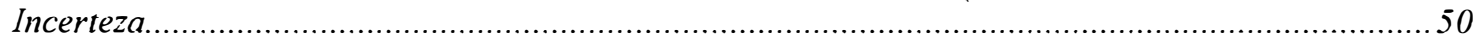

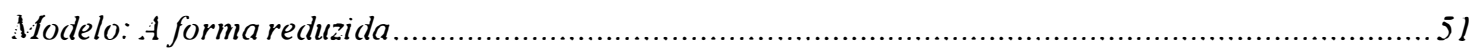

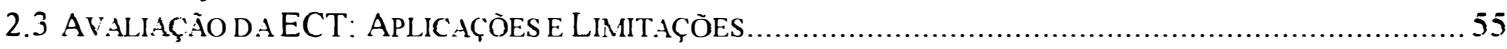

3. ANÁLISE DAS TRANSAÇÕES NO SAG DA CELULOSE - ESTUDO DE CASO.......................60

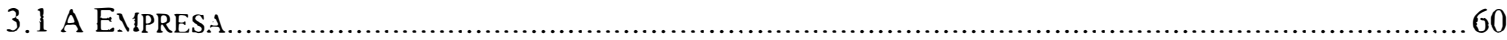

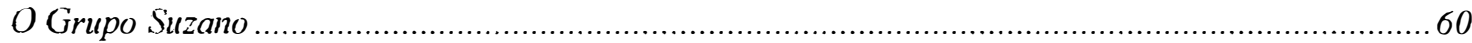

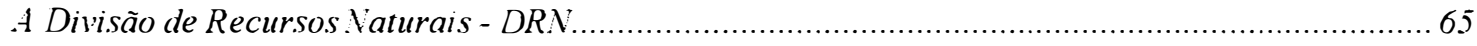

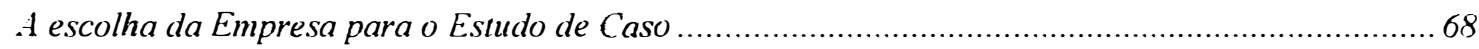

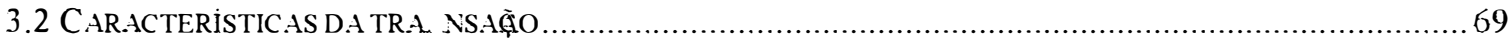

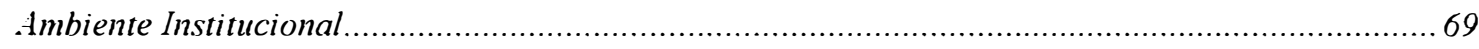

Quantificando a ECT: estimativas para os atributos e custos de transação.....................................8 80

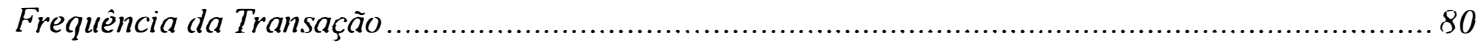

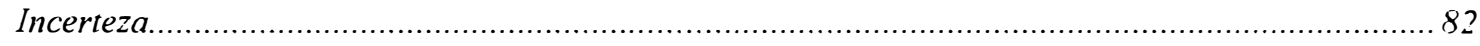

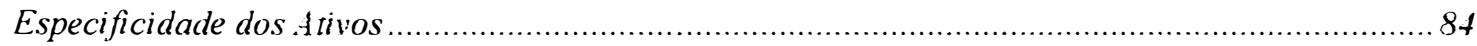

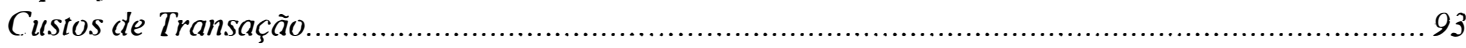

3.3 ESTRUTURAS DE GOVERNANÇ.A ESPERADAS PAR.A O ABASTECIMENTO ….................................... 100

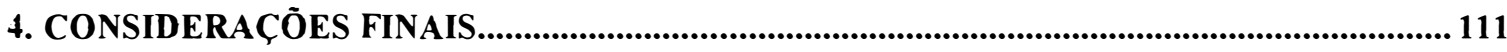

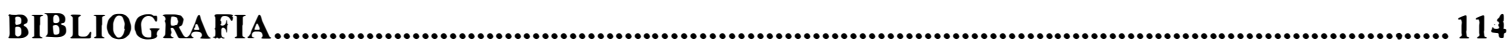




\section{LISTA DE FiguRAS}

Página

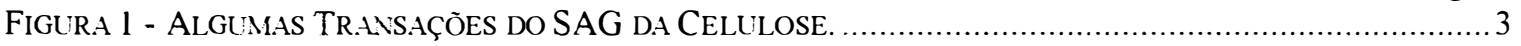

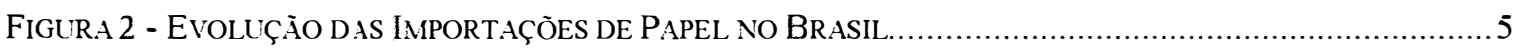

Figura 3 - Mão de Obr.a EMpregada na Produção de Pastas. Papel e Artefatos.............................

Figura 4 - Sistema Agroindustrial da Celulose no Brasil.......................................................

Figura 5 - Custos de Produção de Celulose de Fibra CurTa ...................................................... 17

Figura 6 - Participação das EMpresas Nacionais na Produção de Celulose de Mercado ............. 20

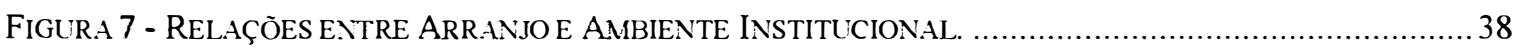

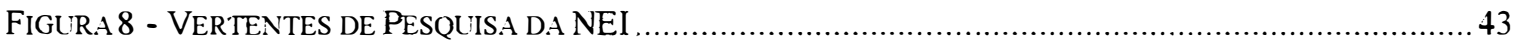

Figura 9 - ESTRUTURA DE GOVERNANÇA RESULTANTE DA RELAÇÃo ENTRE INCERTEZA E ESPECIFICIDADE.51

Figura 10 -Relação entre Custos de Trans.ç̧̇o (CT) E Especificidade de Ativos (K) ...................54

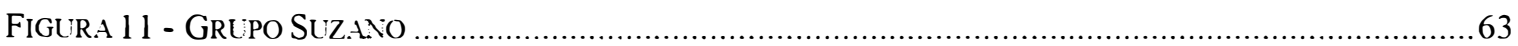

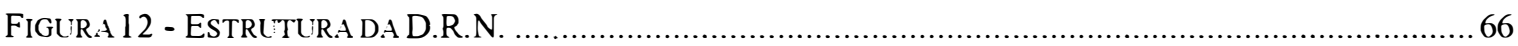

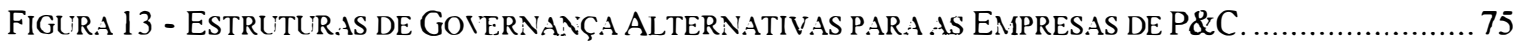

Figura 14 - QUadro Erolutivo da LEGISLAÇão de INCENTIVOS Fiscais E REPOSIÇ.̃o FloRESTAL ....... 78

Figura 15 - Composiç.̃o do Abastecimento Mensal da Fảbric. de Celulose (1993 a 1996) ..........83

Figura 16 - Utilização da Madeira de Florestas Plantadas jo Estado de S.P. (\%)) ...................... 86

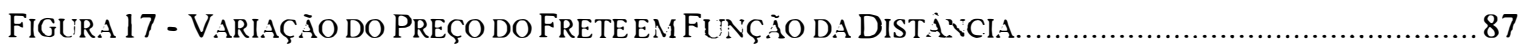

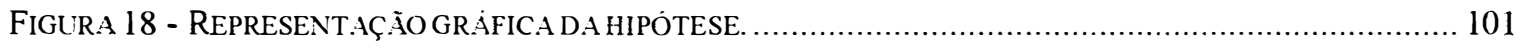

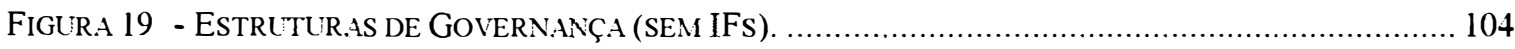

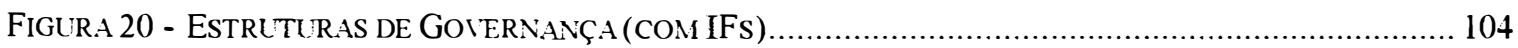

FIGURA 21 - EFEITO DO FIM DOS IFS SOBRE AS ESTRUTURAS DE GOIERNANÇA........................................ 109 


\section{LISTA DE TABELAS}

Página

T.abela l - Programas de Fomento Florestal nas Empres as de Papel e Celllose ........................... 7

T.ABELA2 - Destino da Produção de Celllose Brasileira eN 1995 …........................................... 18

Tabela 3 - Vendas no Mercado Externo de Pasta Quimica de Fibra Curta Por E.ipres a.............. 21

Tabela 4 - Vendas no Mercado Domestico de Pasta Químic a de Fibra CuRTa Por E.rpresa .......... 21

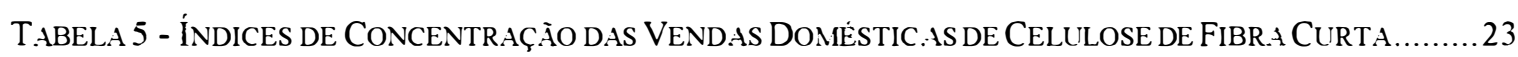

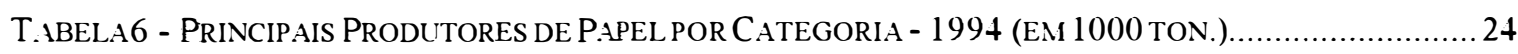

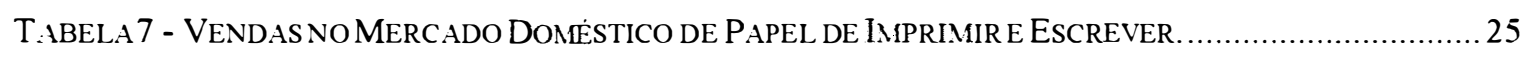

TABELA 8 - VENDAS NO MERCADO EXTERNO DE PAPEL DE IMPRIMIR E ESCREVER. .....................................25

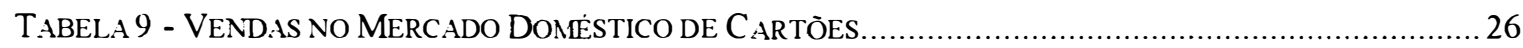

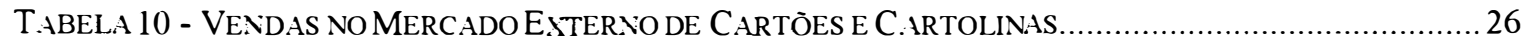

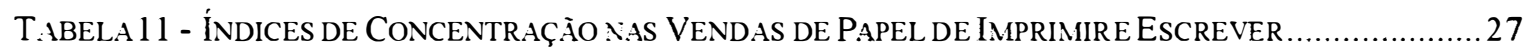

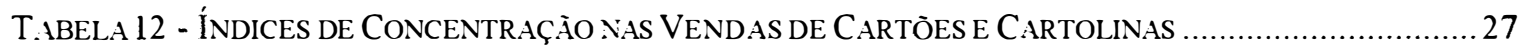

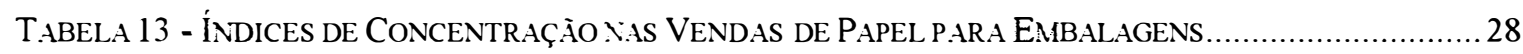

T.abela 14 - Variaiveis Relevantes: ANalise E strutural Discreta Comparativa de SAGs ...........52

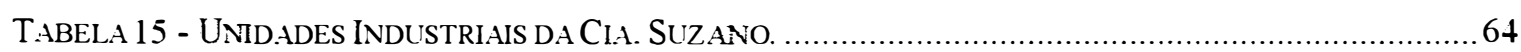

T.ABELA 16 - ABASTECINENTO COM MADEIRA PRÓPRIA E Do Fo.iEnTo (1993 A 1996) ...............................68

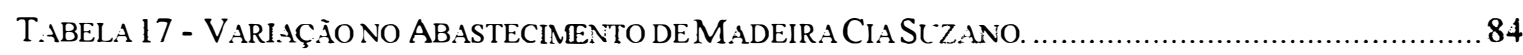

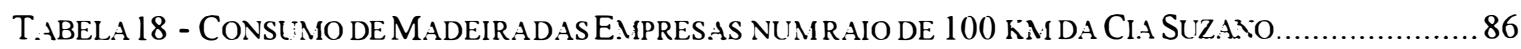

T.ABELA 19 -VOLLTIE DE MADEIRA TRANSPORT.ADO DAS FLOREST.ASE DEPÓSITOS P.AR.A FABRICAS (1995). 88

T.ABELA.20 - Estrutura DE CÁlCUlo daEsPECIFICIDADE DA MLADEIRA.............................................91

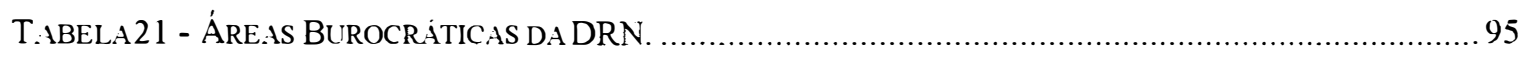

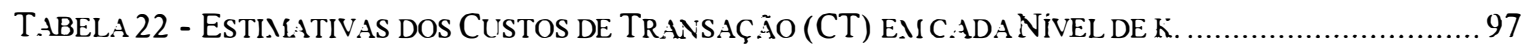

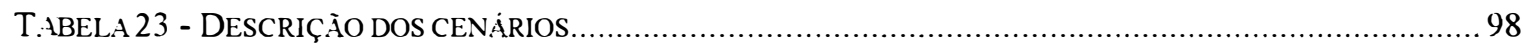

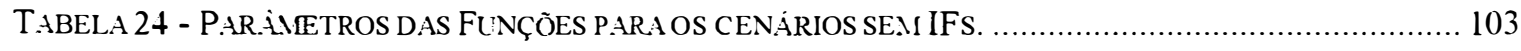

T.ABEL.A25 - PAR.AIETROS DAS FUNÇÕES P.AR.AOS CENARIOS COM IFS............................................... 103

T.ABELA26 - AB.ASTECIMENTO COM MADEIR.A PRÓPRIA E DO FoliE.tTO (93 A 96) .................................. 106

T.ABELA27 - EsTRLTURAS DE GOVERNANÇ. DE IENOR C.T. POR .NIVEL DE K. COM E SEM IFS................... 108 


\section{Abastecimento de Madeira para a Produção de Celulose: UMA APLICAÇÃO DA ECONOMIA dOS CUSTOS DE TRANSAÇÃO}

Autora: ANA RAQUel Bueno MORAEs Ribeiro Orientador: Prof. Dr. LuIZ CARLOS ESTRAviz RODRIGUEZ

\section{RESUMO}

Neste trabalho foram utilizados os conceitos da ECT em dois momentos da história do sistema agroindustrial da celulose no Brasil. Tais momentos, caracterizados por diferentes ambientes institucionais, são: o período de estabelecimento da indústria de celulose no país e o momento atual, em que não mais vigoram os incentivos fiscais ao reflorestamento e a abertura do mercado nacional internacionalizou a concorrência entre as empresas.

A transação analisada foi o abastecimento da fábrica de celulose com madeira, num estudo de caso envolvendo a Cia. Suzano de Papel e Celulose. Testou-se a hipótese de que mesmo com o fim dos incentivos fiscais ao reflorestamento, as características de especificidade do ativo, frequência e incerteza da transação levarão a empresa a manter a estrutura de governança predominantemente hierárquica.

Dada a ausência de estruturas de governança alternativas empiricamente observáveis, foram procuradas variáveis proxy para especificidade do ativo e custos de transação, tornando possivel a estimação de funções que relacionem tais variáveis.

A variável proxy utilizada para os custos de transação foi o valor dos custos essencialmente burocráticos associados a cada estrutura de governança, a exemplo dos custos da alta gerência na grande corporação. Quanto à especificidade do ativo, buscouse um indicador do valor da madeira na produção de celulose capaz de refletir as principais especificidades da transação estudada (ativo dedicado, locacional e fisica). Tal indicador é fundamentalmente o custo da madeira na produção de celulose (US\$ $/ \mathrm{kg}$ de 
celulose). A especificidade da madeira deve aumentar a medida que se produz mais celulose por dólar investido em madeira, portanto pode ser representada pelo inverso do custo ( $\mathrm{kg}$ de celulose / US\$).

Os resultados encontrados demonstram que a empresa escolheu as estruturas de governança mais adequadas tanto no período de vigência dos Incentivos Fiscais ao Reflorestamento (IFs) como ao final deste. Se por um lado, era interessante buscar uma estrutura 100\% hierárquica enquanto havia IFs, hoje, as estruturas de menor custo de transação são compostas $80 \%$ pela hierarquia.

Em termos teóricos, o que se constata é que a ECT oferece um ferramental bastante rico para a análise da questão organizacional, permitindo a interpretação dos fatos sob uma ótica realista e consistente com o comportamento das empresas.

Quanto à tentativa de estimação de custos e atributos da transação, acredita-se que este é um caminho de utilização da teoria suscetível a críticas e erros, porém completamente coerente com as necessidades atuais de avanço da teoria.

Este trabalho traz uma proposta de quantificação da ECT compativel com a teoria e capaz de produzir análises empíricas. Trata-se de um modelo específico, baseado em informações de uma única empresa, e que pode ser estendido para outras empresas deste ou de outros SAGs. 


\title{
WOOD SUPPLY FOR PULP PRODUCTION: AN APPliEd Transaction COST ECONOMICS STUdy
}

\author{
Author: ANA RAQUEL BUENO MORAES RIBEIRO \\ Adviser: Prof. Dr. Luiz Carlos Estraviz RodRiguez
}

\section{SUMMARY}

In this work the Transaction Cost Economics concepts were used in two moments of the history of Brazilian pulp and paper industry. Such moments, characterized by different institutional environment, are: the period of establishment of the pulp and paper industry in the country and after that, when the tax incentives were abolished and the opening of national economy brought the international competition among the companies.

The transaction of analysis was the wood supply in pulp plants (factories), and a case study was developed using data from Cia. Suzano de Papel e Celulose. The tested hypotheses was that the transaction attributes (assets specificity, frequency and uncertainty) will make the company keep its mainly verticalized structure of governance for the wood supply even with the end of tax incentives.

Because of the lack of alternative structures of governance empirically observable, there were established proxy variables to asset specificity and transaction costs, making possible the estimation of functions that relate such variables.

The transaction cost proxy variable was the value of burocratic costs of each governance structure, such as the costs associated to high administration in large companies. The proxy variable for asset specificity was based on the wood value for pulp production (US\$/ ton of pulp). The specificity value must increase as it becomes possible to produce more pulp for each dollar spent in wood, so the specificity value can be represented by the opposite of the cost (kg of pulp / US\$). 
The results show that the structure of governance $100 \%$ verticalized used to be the best option when there were tax incentives. But now the lowest transaction cost is obtained with the governance structure composed of $20 \%$ long term contracts.

Regarding the theory, the Transaction Cost Economics offers a rich theoretical tool for the analysis of organizational forms, making possible the interpretation of facts in a realistic way and according to the companies behavior.

The attempt to estimate costs and attributes of transaction is an approach of the theory totally aligned with the current demands for its development, however, mainly because of this fact, such approach is susceptible of critics and errors.

This work brings a quantification proposal for Transaction Cost Economics capable of producing an interesting empirical analysis. Although the analysis developed in this work can be considered specific, because of the utilization of data from one company, the developed model is generic enough to be applied in other companies. 


\section{INTRODUÇÃO}

A discussão em torno da escolha de formas alternativas de organização da produção tem ganhado importância nas últimas décadas, seja no meio acadêmico em função da controvérsia teórica que o tema inspira, ou no meio empresarial onde há a necessidade de soluções empíricas para esta questão.

A sobrevivência das organizações está cada vez mais vinculada à otimização de processos de produção e gerenciais, que permita às empresas oferecer um produto de qualidade compativel com as exigências de mercado a preços reduzidos. Em função deste fato, muitas são as tentativas de mudanças organizacionais na busca incessante de eficiência nas empresas, como é o caso das terceirizações e verticalizações. Porém, as decisões tomadas nem sempre baseiam-se em uma análise sistêmica, e mais completa, que a simples comparação de custos de produção.

É nesse contexto que a Nova Economia Institucional surge como principal referência teórica para a explicação do processo de escolha das formas organizacionais, tendo na Economia dos Custos de Transação o seu ramo de pesquisa mais voltado para esse tipo de questão (Azevedo, 1996).

O presente trabalho traz um estudo do sistema agroindustrial da celulose de eucalipto no Brasil, desenvolvido sob a ótica de agribusiness da Universidade de Harvard, bem como da Economia dos Custos de Transação. O enfoque deste estudo foi dado às relações contratuais estabelecidas para o abastecimento da indústria com madeira. Para esta transação foi avaliada a atual estrutura de governança adotada por uma empresa, procurando-se responder uma pergunta-chave: dadas as características do novo ambiente institucional sem incentivos fiscais ao reflorestamento, especificidade dos ativos envolvidos, frequência da transação e incertezas associadas à transação, é mais vantajoso comprar ou produzir madeira? 
Os resultados gerados no trabalho podem ser resumidos em dois grupos. O primeiro resulta da discussão e análise da questão organizacional em uma transação específica. O segundo grupo procura enriquecer a teoria, contribuindo com um modelo quantitativo capaz de estimar funções que relacionam proxies dos custos de transação e dos atributos da transação.

\section{Motivação do Trabalho: O Novo Ambiente Institucional}

A compreensão da importância desta dissertação depende da contextualização do ambiente institucional em que se insere atualmente a indústria brasileira de papel e celulose. Para isso, nesta etapa do trabalho serão apresentados de forma suscinta: o Sistema Agroindustrial (SAG) da Celulose no Brasil, a transação foco da análise e as evidências tanto da pressão por competitividade que o SAG vem sofrendo, como dos efeitos desta pressão na transação analisada.

O sistema agroindustrial da celulose pode ser esquematizado como mostra a Figura 1. Os estágios de produção fundamentais estão indicados por retângulos, os insumos agrícolas por um círculo e os serviços utilizados na produção florestal estão sem contorno. Nesse esquema, foram explicitadas formas alternativas de coordenação de algumas das transações no SAG da celulose, indicadas por $T_{n}(n=1$ a 6$)$.

Neste trabalho, o foco de análise será o abastecimento da fábrica de celulose, indicado na figura como a transação T4 (estrutura verticalizada para a produção de madeira) e T4' (compra de madeira). 


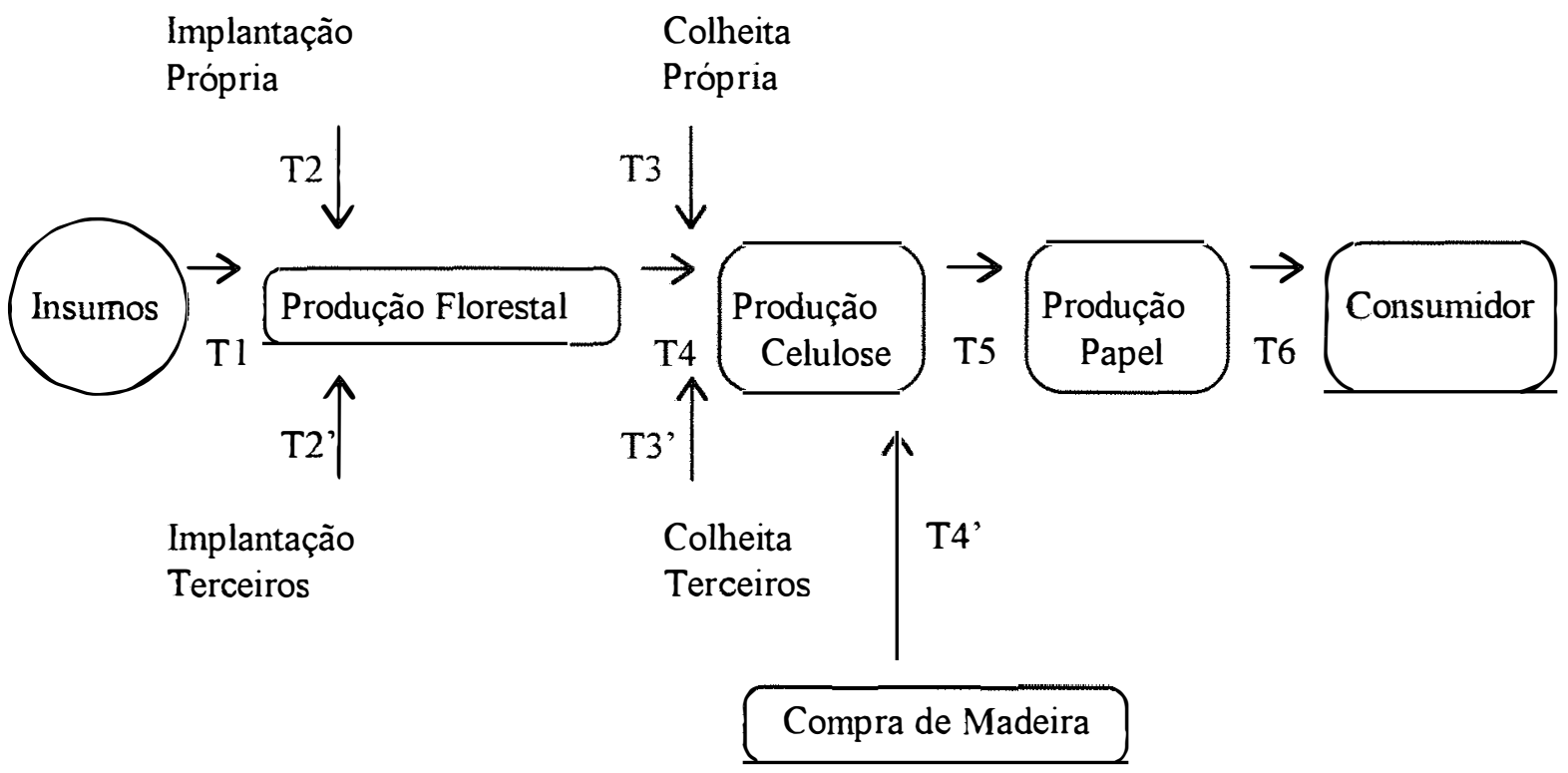

Figura 1 - Algumas Transaçôes do SAG da Celulose.

Fonte: Adaptado de Williamson (1985)

A análise da transação de abastecimento de madeira depende da compreensão do ambiente institucional a que se sujeita a indústria de celulose e papel brasileira após o fim dos Incentivos Fiscais ao Reflorestamento e a recente internacionalização da concorrência que pressiona as empresas por agilidade, qualidade e eficiência.

De forma bastante objetiva, o fim dos incentivos fiscais representa um aumento de custo, uma vez que o Estado arcava com os principais custos da produção florestal (implantação e manutenção dos plantios). Esta elevação de custos da atividade florestal ocorre no momento em que a pressão por competitividade, compreendida como eficiência sustentada no longo prazo, transcende o limite das empresas e atinge todo o sistema agroindustrial (SAG).

A indústria brasileira de papel e celulose constitui-se num oligopólio bastante expressivo na economia nacional. Tal indústria conta com grandes vantagens comparativas na 
produção de energia e de madeira (clima e solo que favorecem o crescimento da floresta e disponibilidade de terras) e boa base tecnológica (empresas líderes em máquinas e equipamentos para o setor estão instaladas no País e suprem $90 \%$ das necessidades das empresas brasileiras). No entanto, o porte das empresas brasileiras face aos concorrentes internacionais, tanto em termos financeiros quanto na escala de produção, constitui um dos pontos frágeis do setor (ANFPC, 1995).

De fato, segundo o ranking publicado por Matussek, Pappens e Brennan (1995), apenas quatro grupos nacionais encontram-se entre os 150 maiores do mundo ${ }^{1}$ (Klabin, Votorantim, Aracruz e Suzano/Nemo Feffer), sendo a melhor colocação o $52^{\circ}$ lugar. Além disso, o projeto Bahia Sul, que custou US\$ 1,5 bilhão, e representou o maior investimento individual dos anos noventa no Brasil, representa um investimento equivalente ao do próprio patrimônio do grupo que o controla (Suzano/Nemo Feffer). O tamanho relativo dos grupos internacionais frente aos brasileiros torna preocupante a agressividade da concorrência estabelecida, particularmente no mercado interno.

Nos últimos anos, a concorrência internacional no mercado interno de papel, gerada pela abertura comercial, e o desfavorecimento das exportações, em função da política cambial, vem exigindo da indústria nacional maior eficiência e competitividade. $\mathrm{O}$ volume das importações de papel dos últimos anos é uma evidência desta concorrência.

\footnotetext{
${ }^{1} \mathrm{O}$ ranking utilizou como critério de ordenamento as vendas realizadas no ano de 94 . em milhões de dólares.
} 


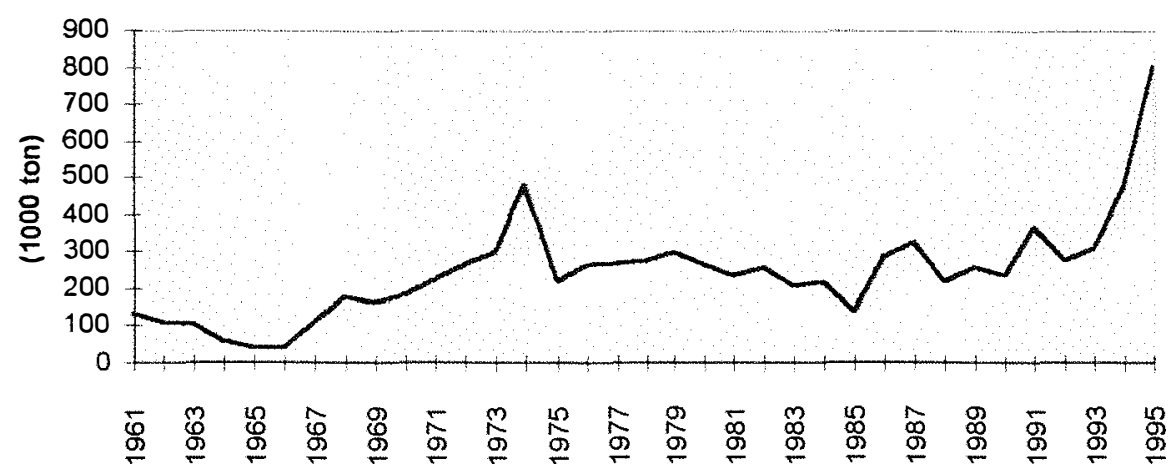

Figura 2 - Evolução das Importações de Papel no Brasil. Fonte: FAO (1994); PPI - Anual Review (1995); PPI - Anual Review (1996)

Os últimos anos foram particularmente delicados também em função da ausência dos incentivos fiscais ao reflorestamento e dos planos de investimento das empresas, em pleno andamento e sem a possibilidade de serem suspensos (investimentos, segundo a ANFPC (1995), equivalentes a US\$ 6,7 bilhões entre 1989 e 94).

No momento em que a concorrência foi internacionalizada e a economia do país aberta, as ineficiências organizacionais, gerenciais e de processo, permitidas até então, passaram a ser alvo de atenção das empresas. As estratégias adotadas em resposta aos desafios da concorrência incluem a redução de preços, melhoria da qualidade, cumprimento rigoroso das especificações de produtos e processos, inclusive de natureza ecológica, e aumento da interação e assistência aos clientes (ANFPC, 1995).

Com relação às questões administrativas, observa-se uma busca intensa da modernização dos métodos de gestão. Mas, as principais alterações observadas nas empresas são o enxugamento de quadro de funcionários e a intensificação da terceirização de atividades 
produtivas. Como ilustra o gráfico abaixo, desde 1990 até 1995, o número de empregos na produção de pastas, papel e artefatos foi reduzido em cerca de $21 \%$.

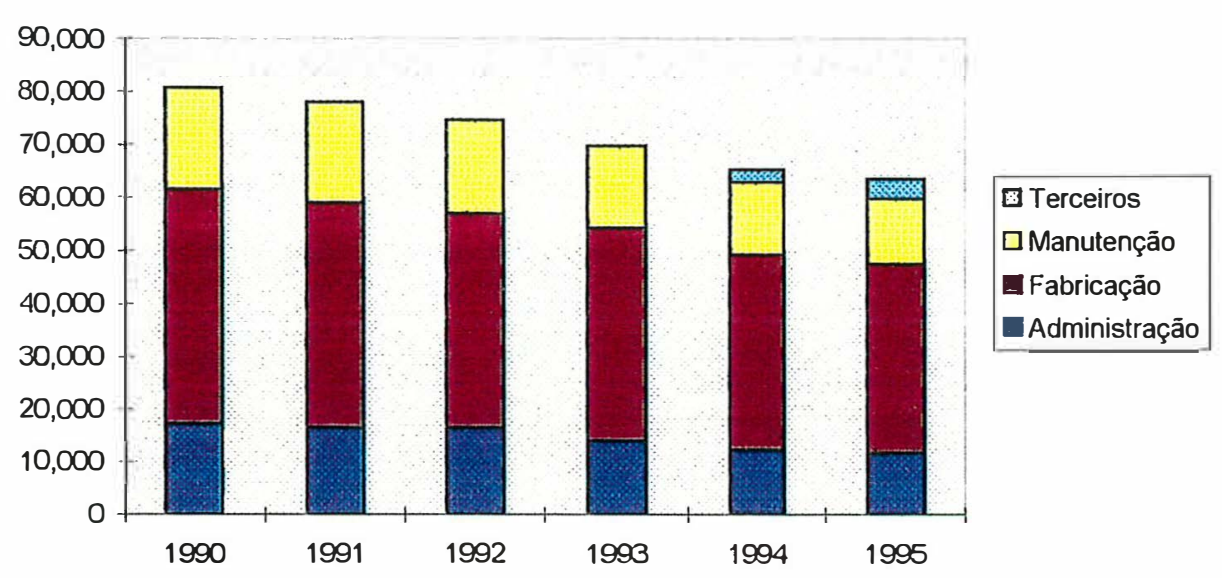

Figura 3 - Mão de Obra Empregada na Produção de Pastas, Papel e Artefatos. Fonte: ANFPC (1992); ANFPC (1994); ANFPC (1996).

Associada ao processo de terceirização, a decisão entre comprar ou fazer participa do cotidiano dos gestores das empresas florestais. Apesar disso, não está disponível para as empresas uma análise mais criteriosa desta questão.

Tradicionalmente, a análise das alternativas de terceirização e integração limita-se à comparação entre os custos de produção associados a cada uma das formas organizacionais. Raramente são avaliados os impactos desta decisão na cadeia produtiva de forma sistêmica, o que muitas vezes gera ineficiências de elevado custo para as empresas.

Particularmente no caso da transação de abastecimento das fábricas de celulose, foco deste trabalho, a escolha entre comprar ou fazer apresenta uma importância bastante grande, dada a mudança na legislação que permitia a utilização de recursos físcais em projetos de reflorestamento. 
Larson, Rodriguez e Azevedo (1994) mostram que vários dos programas de fomento florestal tiveram início nas empresas brasileiras de papel e celulose após 1986. Entre os motivos que os autores apontam como causa para o aumento do número de programas de fomento, está o fim dos incentivos fiscais ao florestamento e reflorestamento em 1988, que elevaram o custo de produção de florestas próprias.

Tabela 1 - Programas de Fomento Florestal nas Empresas de Papel e Celulose.

\begin{tabular}{||c|c|c|c|c|c|c|c|c|c||}
\cline { 2 - 9 } \multicolumn{1}{c|}{} & Aracruz & Champion & Cenibra & Riocell & Pains & Ripasa & Inpacel & Suzano* & Bahia Sul \\
\hline $\begin{array}{l}\text { Início do } \\
\text { Fomento }\end{array}$ & 1989 & 1960 & 1985 & 1989 & 1988 & 1991 & 1991 & 1973 & 1992 \\
\hline $\begin{array}{l}\text { Área Própria } \\
\text { Plantada (ha) }\end{array}$ & 131.000 & nd & 87.935 & 52.487 & 51.467 & 50.365 & 25.768 & 48.079 & 66.902 \\
\hline $\begin{array}{l}\text { Área Fom. } \\
\text { Plantada (ha) }\end{array}$ & 30.000 & 13.000 & 8.500 & 4.985 & 2.431 & 2.425 & 1.575 & 16.814 & 850 \\
\hline$\%$ Área Fom. & 22,90 & n.d. & 9,67 & 9,50 & 4,72 & 4,81 & 6,11 & 34,97 & 1,27 \\
\hline
\end{tabular}

Fonte: Larson. Rodriguez e Azevedo (1994) : ${ }^{*}$ Informaçòes coletadas na Cia Suzano de Papel e Celulose

Frente a esta movimentação das empresas no sentido de ampliar os programas de fomento, algumas questões emergem. Qual forma organizacional deve ser adotada para o abastecimento das fábricas de celulose? Até que ponto esta tendência de reorganização das empresas se efetivará em terceirização completa da base florestal? 


\section{Hipótese do Trabalho}

A partir dos conceitos da Economia dos Custos de Transação, que serão apresentados no capitulo 2 deste trabalho, formulou-se a seguinte hipótese:

"A ausência dos incentivos fiscais ao reflorestamento eleva os custos de produção, estimulando a terceirização da base florestal. Porém, o aumento no custo de transação gerado pela escolha da estrutura contratual (dadas as características da transação) deve ser maior que a redução nos custos de produção conseguida com esta. Assim, mesmo na ausência dos incentivos fiscais ao reflorestamento, a estrutura predominantemente hierárquica deve manter-se."

No momento atual, em que a redução de custos e o aumento da eficiência são os lemas das empresas, e que se faz necessário fortalecer todos os elos da cadeia produtiva, é fundamental garantir que o abastecimento das fábricas de celulose com o produto florestal também seja eficientemente realizado. Testando a hipótese apresentada, este trabalho busca contribuir para que tal objetivo seja atingido.

\section{Estrutura da Dissertação}

O texto que se segue pode ser lido sob dois enfoques, dependendo do interesse do leitor. A primeira leitura traz como problema central a escolha da forma organizacional da base florestal nas empresas produtoras de celulose. A segunda leitura, mais interessante aos leitores que buscam aplicações empíricas da Economia dos Custos de Transação, focaliza a teoria e sua aplicação em um modelo de quantificação da especificidade do ativo e de proxies para os custos de transação. 
Considerando-se que cada capítulo foi estruturado como uma unidade completa, a leitura parcial do trabalho é perfeitamente possivel. Para os interessados em obter informações a respeito da indústria nacional de celulose e papel, sugere-se a leitura do primeiro capítulo. Nele, está apresentada uma caracterização do sistema agroindustrial da celulose no Brasil, sua importância e desafios atuais.

Para os leitores interessados nas questões teóricas sugere-se a leitura do segundo capítulo que descreve o surgimento da Economia dos Custos de Transação e seus conceitos básicos, dando ênfase à forma como se propõe a análise da decisão entre as formas alternativas de coordenação vertical.

No terceiro capítulo encontram-se as duas principais contribuições da dissertação, mencionadas anteriormente. Através de um estudo de caso empírico, são utilizados os conceitos de ECT para a formulação e teste da hipótese sobre as estruturas de governança adotadas no abastecimento de uma empresa específica. O terceiro capítulo interessa tanto aos que buscam uma análise da escolha da estrutura de governança no abastecimento de madeira em uma empresa de celulose e papel, como aos que estejam interessados num modelo quantitativo baseado nos conceitos da ECT.

O quarto, e último capitulo, apresenta as considerações finais e algumas recomendações para trabalhos futuros. 


\section{OBjetrvos}

1. Caracterizar o abastecimento de madeira no sistema agroindustrial da celulose no Brasil.

2. Avaliar a adequação do modelo proposto pela Economia dos Custos de Transação para explicar o alto grau de verticalização das empresas produtoras de celulose no abastecimento de madeira.

3. Justificar determinadas expectativas de reorganização do abastecimento de madeira nas empresas em função da mudança no ambiente institucional, particularmente, do término dos Incentivos Fiscais ao Reflorestamento.

4. Criar um modelo de quantificação da especificidade do ativo e de proxies para os custos de transação. 


\section{O Sistema Agroindustrial da Celulose no Brasil}

Neste capítulo do trabalho será apresentada uma caracterização da indústria brasileira de papel e celulose, ressaltando sua importância para a economia nacional e sua inserção no mercado mundial.

O Sistema Agroindustrial brasileiro da Celulose desenvolveu-se em etapas sucessivas de verticalização e de substituição de importações de insumos. No final do século XIX e início do século $\mathrm{XX}$, a produção de papel atendeu à demanda de empresas gráficas e de artefatos de papel para embalagens leves, utilizando-se de celulose importada ${ }^{2}$, trapos e aparas. Nas décadas de 20 e 30, com a proteção tarifária ao produto nacional, houve intensa expansão das empresas no setor. Entre 1933 e 1939, a produção de papel triplicou e impulsionou a fabricação de celulose pelo processo sulfito ${ }^{3}$.

A integração da produção de celulose à de papel foi reforçada no governo Kubitschek (1956 - 1960). O Plano de Metas, criado na época, estabeleceu a meta de auto-suficiência nacional em celulose. O governo exerceu ação coordenadora, elevou a proteção tarifária à produção local, criou mecanismos de financiamento (BNDE) e ampliou a oferta de infra estrutura em energia e transportes. $\mathrm{O}$ aumento na oferta de celulose ficou a cargo dos produtores privados, empresas nacionais ou empresas de capital estrangeiro instaladas no País. A capacidade produtiva em celulose sulfato cresceu substancialmente, estimulada

\footnotetext{
2 Celulose é um carboidrato (polissacarídeo hexosana), componente das paredes das células vegetais (Koga, 1988). Estas células. também chamadas de fibras, são unidas por uma substância chamada lignina para compor a estrutura dos regetais. O processo de isolamento das fibras. através do uso de substâncias químicas para a extração da lignina. é conhecido como polpeamento químico. e corresponde a um dos processos de produção das chamadas "pastas celulósicas" e "celulose de mercado". Estes são dois termos genéricos dados à massa composta por um conjunto de fibras vegetais isoladas. comercializada no mercado e utilizada principalmente para a fabricação de papéis. Neste trabalho. o termo "celulose". referente à subtância química componente dos vegetais, será utilizado como sinônimo dos produtos comerciais: "pasta celulósica" e "celulose de mercado".

${ }^{3}$ Processo químico de polpeamento que utiliza reagentes ácidos, pouco utilizado atualmente.
} 
pela viabilização técnica e econômica da celulose de eucalipto ${ }^{4}$. A partir de 1957 , as fábricas integradas instaladas no Pais passaram a fornecer papel com 100\% de celulose nacional. A consolidação da indústria, no entanto, só aconteceu mais tarde, com os incentivos do Estado (Gazeta Mercantil, 1996).

Em 1965, o governo atualizou o Código Florestal, criou o IBDF e ofereceu incentivos fiscais à indústria e, a partir de 1966, beneficiou a implantação e manutenção de maciços florestais. Mais tarde, o periodo do "milagre econômico" (1968 a 1973) marcou a integração do suprimento de madeira às plantas industriais instaladas.

Segundo dados da Associação Nacional dos Fabricantes de Papel e Celulose - ANFPC (1995), entre 1974 e 79, o setor iniciou um novo e vigoroso ciclo de expansão. As propostas estratégicas do II PND - Plano Nacional de Desenvolvimento e do I Plano Nacional de Papel e Celulose, articuladas no âmbito do Conselho de Desenvolvimento Industrial (CDI), eram alcançar auto-abastecimento no País e lançar projetos de exportação de celulose. A política de estímulo ao setor envolveu concessão de financiamento público e incentivo fiscal à expansão de escalas de capacidade produtiva, à formação de florestas para o suprimento de madeira e ao desenvolvimento tecnológico e melhoria da eficiência das unidades produtivas. O governo federal teve participação vital na implantação do segmento de celulose de mercado, via BNDESPAR, Banco do Brasil e $\mathrm{CVRD}^{5}$. O BNDE apoiou os planos de crescimento então realizados, proporcionando o capital necessário às empresas. A capacidade produtiva interna dobrou e consolidou-se definitivamente a produção e o uso da celulose de fibra curta na produção de papel.

\footnotetext{
${ }^{4}$ Cia Suzano. Papel Simão e Champion são pioneiras no aproveitamento da fibra curta de eucalipto destinada a papéis de imprimir e escrever (ANFPC, 1995).

5 Segundo a ANFPC (1995). a Aracruz tinha como principal acionista o BNDE e a Cenibra resultou de uma associação da estatal CVRD com empresas japonesas. As outras duas fábricas de celulose criadas no período pertenciam a investidores externos. A Borregard tinha capital norueguês e a Jari, capital americano. Mas os investidores privados iniciais não tiveram condições de levar adiante os empreendimentos e os transferiram para bancos públicos - Banco do Brasil e BNDE - que mais tarde reprivatizaram os projetos.
} 
Implantaram-se o centro de pesquisa de tecnologia para o setor no IPT, em 1976, e o Programa Nacional de Pesquisa Florestal, na EMBRAPA, em 1978.

O atual sistema agroindustrial da celulose é composto por diversos agentes que atuam no fornecimento de insumos para a produção florestal, na produção de madeira, no processamento da madeira bruta em celulose e esta em papel, cartão e derivados. (Figura 4). A cadeia inclui ainda serviços de transporte rodoviário, ferroviário e marítimo dos produtos fabricados e a recuperação de papel em processos de reciclagem deste material. 


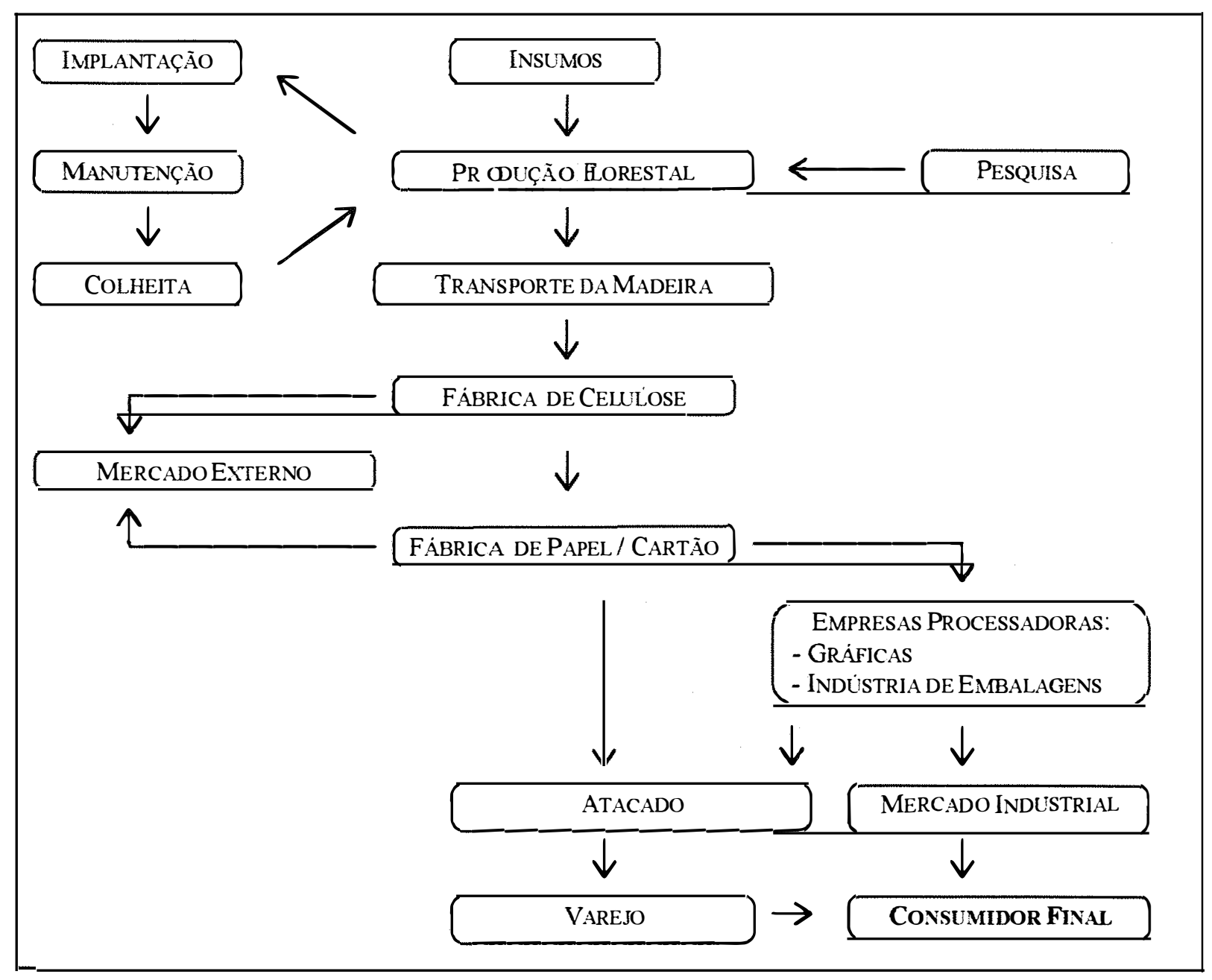

Figura 4 - Sistema Agroind ustrial da Celulose no Brasil 
O complexo produtivo brasileiro de madeira-celulose-papel-artefatos de papel contribui de forma relevante para o desenvolvimento do país. Além de ativar toda a cadeia descrita, os investimentos do complexo têm um forte poder multiplicador de renda, pelo seu estímulo à produção de bens de capital (máquinas, caldeiras, veículos etc.) e à construção de obras civis (instalações produtivas e de tratamento de resíduos) (ANFPC, 1995).

Todas as fábricas de celulose do setor são verticalizadas desde a base florestal, embora nem todas tenham integrado suas atividades até a produção de papel. A partir da Figura 1 é possivel classificar as empresas segundo seu grau de verticalização. $O$ menor grau de verticalização, chamado neste trabalho de tipo 1 , ocorre nas empresas verticalizadas desde a produção de madeira até a de celulose, como é o caso da Aracruz, Cenibra, Jari e Riocell. No tipo 2, estão incluídas as empresas verticalizadas desde a base florestal até a produção de papel ou cartão, a exemplo da Klabin, Champion, Ripasa, Suzano e Bahia Sul. Os tipos 3 e 4 correspondem às empresas que compram respectivamente celulose e papel para a confeç̧ão de seus produtos. Nestes casos há uma infinidade de empresas dispersas pelo país.

As fábricas de celulose não integradas com a produção de papel (tipo 1) são as principais responsáveis pelo fornecimento do produto comercial genericamente conhecido como celulose de mercado. A celulose de mercado inclui vários tipos de celulose, classificados segundo as seguintes características:

1. quanto ao comprimento das fibras: longa (no caso de coníferas) e curta (no caso de folhosas)

2. quanto ao processo de polpeamento ${ }^{6}$ : químico (sulfato ou sulfito), mecânico, termomecânico, quimitermomecânico, semiquímico, entre outros.

3. quanto ao branqueamento: celulose branqueada ou não branqueada.

6 Em rigor, o produto advindo de processos de polpeamento mecânico. termomecânico. quimitermomecânico e semiquímico é um tipo especifico de pasta celulósica chamado de Pasta de Alto Rendimento (PAR). 
A maioria das empresas produtoras de celulose especializou-se em um tipo de fibra, criando as chamadas "linha marrom" e "linha branca" (Macedo e Mattos, 1996). Esta segmentação ocorreu em função do uso diferenciado para cada tipo de fibra. $\mathrm{Na}$ "linha marrom" as essências florestais utilizadas para obtenção da celulose são coníferas, principalmente Pinus spp no Brasil. As fibras destas espécies são longas (de 1,5 a $5 \mathrm{~mm}$ ), o que permite a produção de papéis de elevada resistência à tração, ao rasgo e ao estouro (perfuração), a exemplo de papéis de embalagem, caixas de papelão ondulado e sacos multifolhados. Já na "linha branca" as espécies folhosas, especialmente Eucaliptus spp, são a principal matéria-prima utilizada. As fibras curtas $(0,7$ a $1,4 \mathrm{~mm})$ são aptas para a confecção de papéis de baixa resistência, como os de imprimir e escrever, cartões e sanitários. A maior parte da celulose produzida no Brasil, cerca de $70 \%$, pertence à linha branca (ANFPC, 1995).

Dentre os processos de polpeamento, o mais utilizado é o químico. Em 1995, por exemplo, cerca de $70 \%$ da produção mundial de celulose utilizou processos químicos de polpeamento (PPI, 1996). No Brasil, este valor chega a 92\% (ANFPC, 1995).

Historicamente, observa-se a rápida expansão da produção nacional de papel e celulose. Segundo Macedo e Mattos (1996), entre 1970 e 1994, a taxa média de crescimento da produção de celulose e papel foi de $8,7 \%$ e $6,9 \%$ a.a., respectivamente. Durante o período de forte retração do mercado interno (1981 a 83) o setor manteve sua trajetória de crescimento, ampliando sua participação no comércio internacional, sobretudo nos mercados europeu e latino-americano. Atualmente, o setor atende ao mercado interno em quase todos os segmentos de produtos, realizando a conversão de papel em artefatos de maior valor agregado, e ao mesmo tempo conquistou sua inserção no mercado 
internacional de commodities, basicamente celulose de fibra curta, papéis de imprimir e escrever não revestidos (offset) e papel para embalagem (kraftliner).

No mercado externo, a principal concorrência à celulose de fibra curta brasileira parece vir das economias emergentes na Ásia. As florestas nativas abundantes (exploradas para a produção de celulose), clima favorável ao crescimento de espécies folhosas, baixo custo da mão-de-obra e modernas plantas industriais permitem que países como a Indonésia ofereçam celulose a preços altamente competitivos no mercado internacional. Atualmente, seu custo de produção da celulose de fibra curta branqueada, obtida pelo processo kraft é de US\$250/ton (Johansson, 1996). Este valor é bastante significativo se comparado com os custos de produção de países tradicionais no setor (Figura 5).

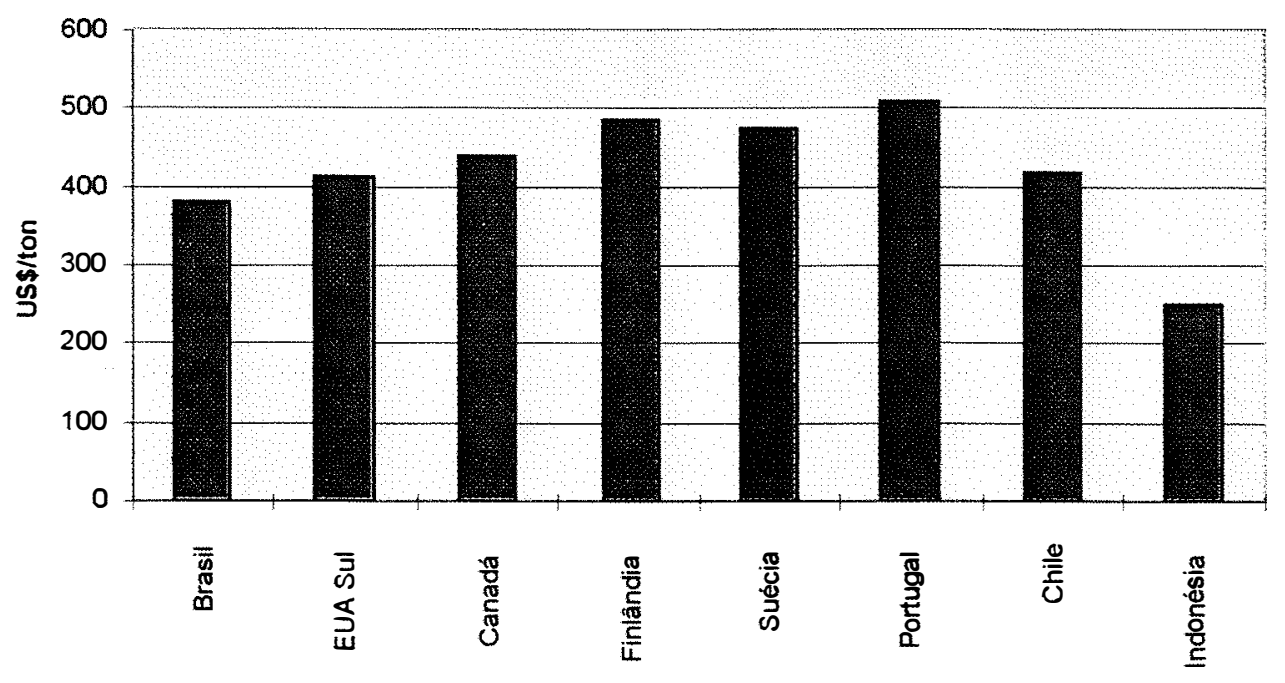

Figura 5 - Custos de Produção de Celulose de Fibra Curta (USS/ton. posta Europa $3^{0}$-trimestre 1994). Fontes: Bueno (1996) e Johansson (1996)

Em 1995, foram produzidas no Brasil 6 milhões de toneladas de celulose, 5,9 milhões de toneladas de papel e 590 mil toneladas de cartão. A oferta destes produtos no mercado 
externo, em 95, foi responsável pela geração de US\$ 2,8 bilhões em exportações. Neste mesmo ano, o faturamento global do setor atingiu US\$ 8,7 bilhões, participando na geração de $1,5 \%$ do PIB brasileiro (C\&P, 1996).

Segundo dados do relatório anual da Pulp \& Paper International, o Brasil ocupou, em 1995, o $7^{\mathbf{0}}$ lugar entre os países produtores de celulose, e é o líder na produção de celulose de eucalipto. Cerca de $55 \%$ da celulose brasileira foi consumida pelas próprias empresas que a produziram, enquanto $32 \%$ foi vendida no mercado externo e os $13 \%$ restantes abasteceram as fábricas de papel nacionais não integradas às plantas industriais de celulose. Tanto no mercado doméstico como no mercado externo, a celulose de fibra curta corresponde à maior parte do total comercializado (78 e 96\%, respectivamente).

Tabela 2 - Destino da Produção de Celulose Brasileira em 1995

\begin{tabular}{|c|c|c|c|c|}
\hline \multicolumn{1}{|c|}{ Destino } & $\begin{array}{c}1994 \\
\text { ton. }\end{array}$ & $\begin{array}{c}1995 \\
\text { ton. }\end{array}$ & $\begin{array}{c}1994 \\
\%\end{array}$ & $\begin{array}{c}1995 \\
\%\end{array}$ \\
\hline \hline Consumo Próprio & $3,069,604$ & $3,187.544$ & $\mathbf{5 2 . 3 6}$ & $\mathbf{5 5 . 2 0}$ \\
Fibra curta & $1,524,444$ & $1,536,683$ & 49.66 & 48.21 \\
Fibra longa & $1,154,002$ & 1.232 .028 & 37.59 & 38.65 \\
Pasta de Alto Rendimento (PAR) & 391.158 & 418.833 & 12.74 & 13.14 \\
\hline & & & & \\
\hline Vendas no mercado doméstico & $\mathbf{7 5 6 , 0 1 1}$ & $\mathbf{7 4 7 . 9 8 8}$ & $\mathbf{1 2 . 9 0}$ & $\mathbf{1 2 . 9 5}$ \\
Fibra curta & 587,416 & 585.014 & $\mathbf{7 7 . 7 0}$ & $\mathbf{7 8 . 2 1}$ \\
Fibra longa & 111.420 & 96.190 & 14.74 & 12.86 \\
Pasta de Alto Rendimento (PAR) & 57,175 & 66.784 & 7.56 & 8.93 \\
\hline & & & & \\
\hline Vendas no mercado externo & $2,036,475$ & 1.838 .531 & $\mathbf{3 4 . 7 4}$ & $\mathbf{3 1 . 8 4}$ \\
Fibra curta & $1,925.638$ & 1.759 .227 & 94.56 & 95.69 \\
Fibra longa & 106,274 & $\mathbf{7 4 , 0 2 6}$ & 5.22 & 4.03 \\
Pasta de Alto Rendimento (PAR) & $\mathbf{4 . 5 6 3}$ & 5.278 & 0.22 & 0.29 \\
\hline & & & & \\
\hline Total & $\mathbf{5 , 8 6 2 , 0 9 0}$ & $\mathbf{5 , 7 7 4 , 0 6 3}$ & $\mathbf{1 0 0}$ & $\mathbf{1 0 0}$ \\
\hline
\end{tabular}

Fonte: ANFPC (1996) 
À imagem da indústria de papel e celulose de todo mundo, no Brasil esta também é bastante concentrada. Segundo dados apresentados na Gazeta Mercantil (1996), apesar da indústria brasileira de papel e celulose contar com cerca de 230 empresas, apenas dez grupos respondem por $65 \%$ da produção de papel e cinco grupos são responsáveis por mais de $80 \%$ da produção de celulose no mercado nacional. Isso deve-se, em parte, ao desenvolvimento tecnológico, às expansões das unidades fabris e, sobretudo, às fusões, aquisições e associações entre empresas.

Exemplos do intenso processo de concentração da produção e restruturação patrimonial da indústria de papel da última década incluem fusões (Manville com Papelock formando a Igaras, Papel Simão com Celpav formando a Votorantim Celulose e Papel), aquisições (Melhoramentos comprando a $\mathrm{KC}$ do Brasil) e associações (joint-venture Klabin-Lenzig e Toga-International Paper, Suzano com Igaras e Suzano com Cia Vale do Rio Doce).

A concentração da produção de celulose é bastante intensa, embora projeções indiquem certa atenuação deste cenário (Figura 6). Em 1994, a Aracruz, maior empresa produtora de celulose de fibra curta do mundo, foi responsável por $39 \%$ da produção de celulose de mercado brasileira. Cenibra, Bahia Sul, Jari e Riocell produziram 14, 11, 9 e 8\%, respectivamente (Macedo e Mattos, 1996). Com a entrada do grupo Votorantim, Celmar e Veracruz neste segmento, no ano 2002, a participação da Aracruz na produção de celulose deve reduzir-se a $27 \%$. 


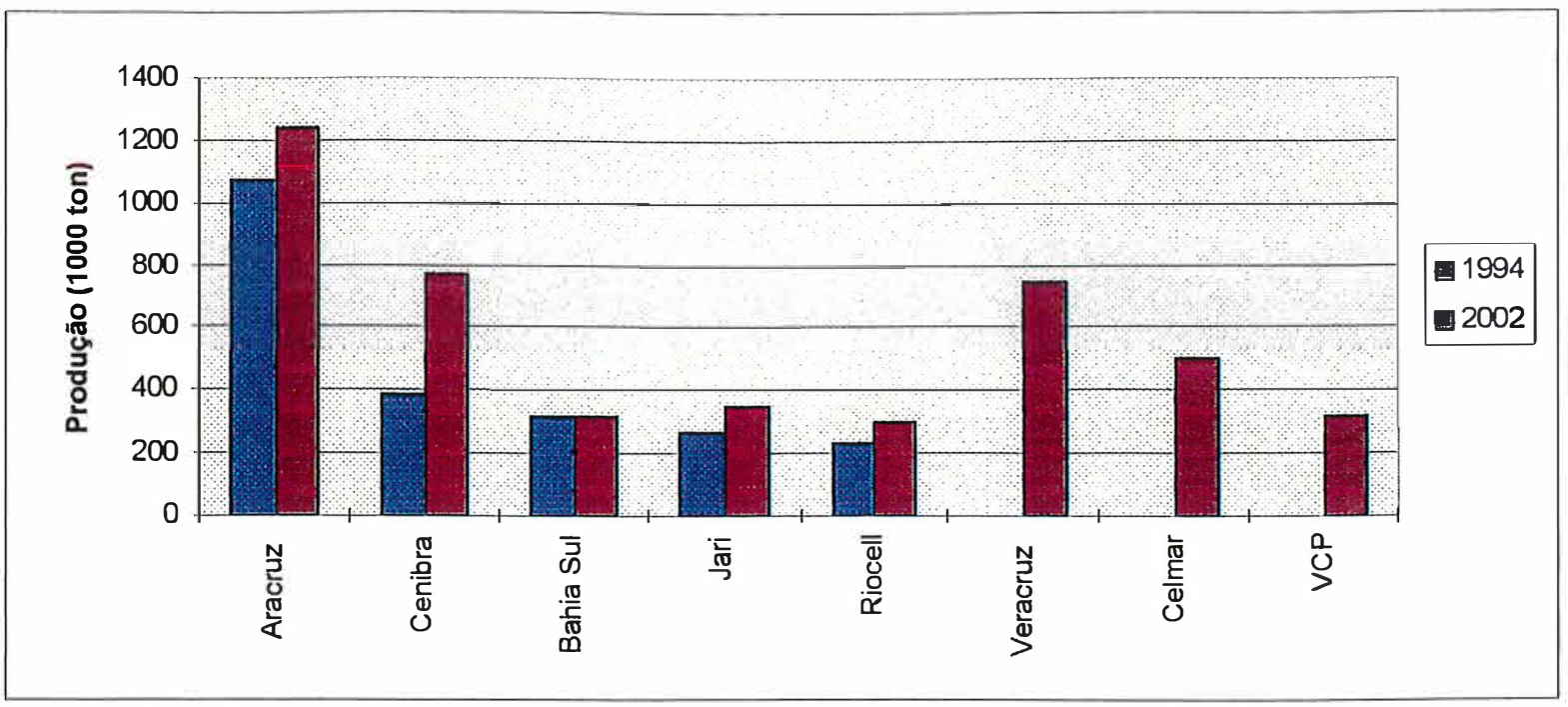

Figura 6 - Participação das Empresas Nacionais na Produção de Celulose de Mercado. Fonte: Macedo e Mattos (1996)

As tabelas 3 e 4 apresentam a participação das empresas brasileiras nas vendas de celulose de fibra curta nos mercados externo e interno, respectivamente, nos anos 90 a 95. A partir destes dados, foram calculados dois índices de concentração: Razão de Concentração ${ }^{7}$ (CR4) e o Índice de Hirschman-Herfindahl $(\mathrm{HH})^{8}$, apresentados na tabela 5.

\footnotetext{
${ }^{7}$ O índice Razão de Concentração é definido como a proporção do valor total da produção da indústria que corresponde às $k$ maiores empresas (Hoffmann, 1991). Usualmente, são somadas as participações das quatro (CR4) ou oito (CR8) maiores empresas.

${ }^{8} \mathrm{O}$ índice $\mathrm{HH}$ é dado pela soma dos quadrados das parcelas de mercado de cada uma das empresas participantes da indústria. Segundo Resende (1994), esse índice é interessante porque ao elevar-se ao quadrado cada parcela de mercado atribui-se um peso maior às parcelas mais expressivas, ressaltando as diferenças entre a participação relativa das empresas e evidenciando o grau de competitividade do mercado.
} 

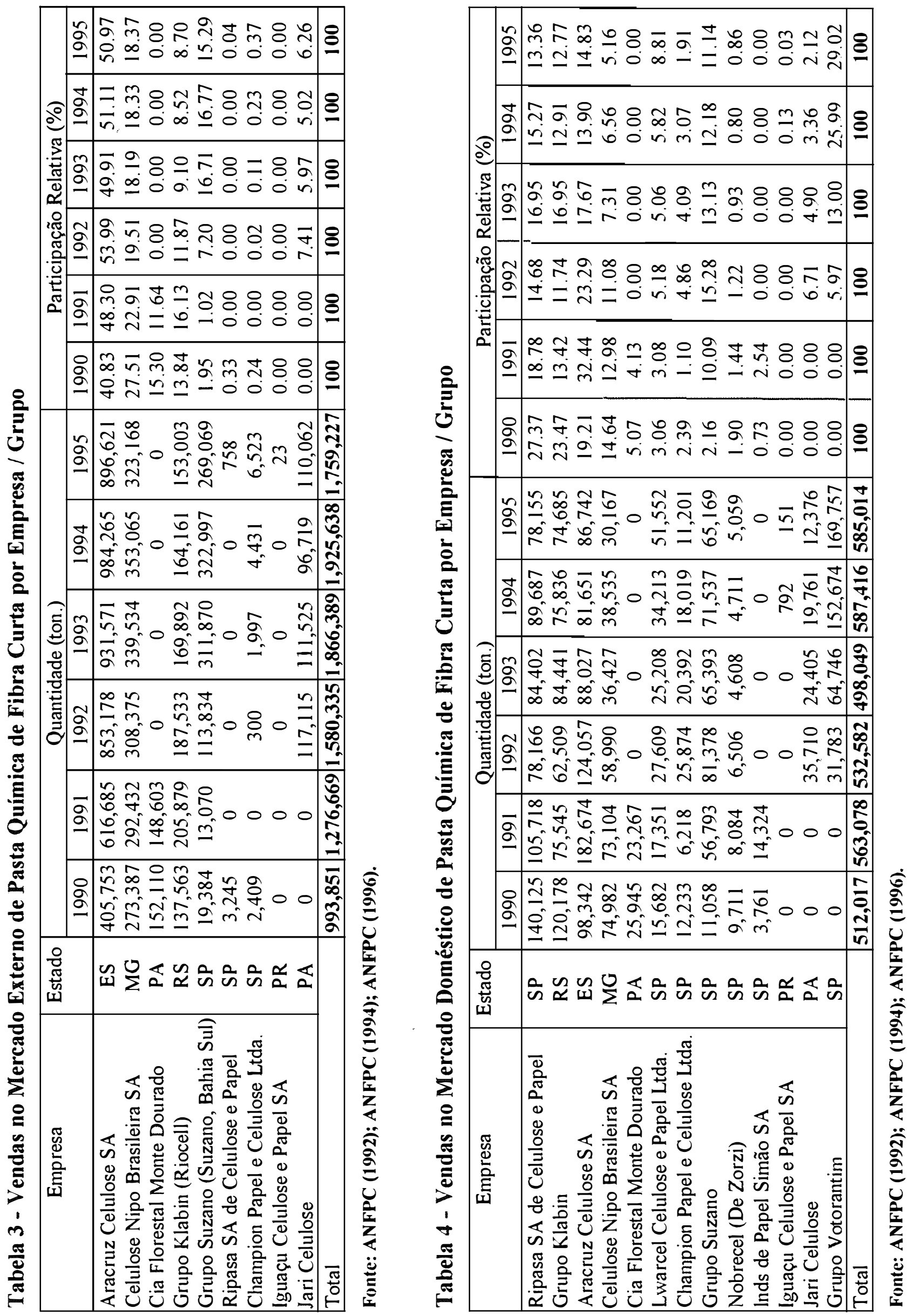
Observa-se na tabela 3 que durante todo o período de análise (1990 a 95) as empresas Aracruz e Cenibra lideraram as vendas de celulose de fibra curta no mercado externo, detendo juntas mais de $60 \%$ do total comercializado. Com a ativação da planta da Bahia Sul, em 1992, o Grupo Suzano passou a ter uma participação mais expressiva nas exportações, entre 7 e $16 \%$. Já o Grupo Klabin teve sua participação reduzida de 13 para cerca de $8 \%$, no mesmo período. Atualmente, a quase totalidade da celulose exportada pelo Brasil, 93,3\%, tem origem em quatro empresas: Aracruz, Cenibra, Bahia Sul (Grupo Suzano) e Riocell (Grupo Klabin).

$\mathrm{Na}$ tabela 4 , observa-se que no mercado doméstico de celulose de fibra curta o número de empresas participantes é mais expressivo e dinâmico comparativamente ao mercado externo. Entre 1990 e 95 ocuparam a liderança nas vendas: Ripasa, Aracruz e Votorantim. Neste mesmo período, as vendas das duas primeiras colocações somaram, em média $43 \%$ do mercado.

É interessante ressaltar a agressividade com que o grupo Votorantim estabeleceu-se no mercado interno da celulose. Após a aquisição da Celpav (antiga Cia Guatapará), em maio de 1988, e do controle acionário das empresas do Grupo Simão, em novembro de 1992, o Grupo Votorantim despontou no mercado doméstico de celulose de fibra curta, conquistando, em 1995, 29\% das vendas e a maior participação individual registrada desde 1990.

A competição estabelecida entre as empresas, nos mercados interno e externo da celulose, pode ser avaliada através dos índices de concentração apresentados na tabela 5. Os valores encontrados para o índice CR4 evidenciam o elevado grau de concentração das vendas domésticas de celulose pelas quatro maiores empresas. Em média o índice foi de $70,87 \%$. No entanto, o segundo índice calculado $(\mathrm{HH})$ demonstra que as parcelas das vendas relativas a cada uma das empresas atuantes no mercado doméstico não são muito distintas. Em outras palavras, existem poucas empresas detendo a maior parte das 
vendas, porém em parcelas razoavelmente equivalentes, de forma que a concorrência entre tais empresas é mais intensa do que possa parecer pelo índice de concentração CR4.

Tabela 5 - Índices de Concentração das Vendas Domésticas de Celulose de Fibra Curta

\begin{tabular}{|c|c|c|c|c|c|c|c|c|c|}
\cline { 2 - 7 } \multicolumn{1}{c|}{} & \multicolumn{7}{c|}{ Índices de Concentração } & \multicolumn{1}{c|}{} \\
\hline & 1990 & 1991 & 1992 & 1993 & 1994 & 1995 & Média & $\begin{array}{c}\text { Desvio } \\
\text { Padrão }\end{array}$ \\
\hline $\begin{array}{c}\text { Razão de Concentração } \\
\text { CR4 }\end{array}$ & 84.69 & 77.62 & 57.59 & 67.27 & 68.07 & 69.97 & 70.87 & 9.32 \\
\hline $\begin{array}{c}\text { Hirschman-Herfindahl } \\
\text { HH }\end{array}$ & 19.33 & 18.92 & 13.44 & 13.80 & 15.15 & 16.41 & 16.17 & 2.52 \\
\hline
\end{tabular}

Fonte: Calculado a partir de dados ANFPC (1992), (1994) e (1996)

De forma semelhante ao mercado de celulose, o mercado de papel é tradicionalmente segmentado pelo uso final dos produtos. Os principais tipos de papéis produzidos no mundo, atualmente, são: papéis de embalagem, papéis de imprimir e escrever, papel de imprensa, papéis para fins sanitários, cartões e cartolinas e papéis para usos especiais (papel carbono, cigarro, térmico etc.). Estes segmentos distinguem-se de forma bastante clara em relação à forma de organização das corporações e às estratégias de marketing para seus produtos. Cerca de $85 \%$ do volume transacionado no mercado mundial de papéis é representado pelos tipos de embalagem, imprimir/escrever e imprensa (Macedo e Valença, 1995).

As maiores fábricas nacionais de papel são integradas verticalmente com as fábricas de celulose, embora haja inúmeras pequenas fábricas de papel não integradas em todo o país. Geograficamente, a produção nacional de papel concentra-se em três estados. Em 1994, $84 \%$ do volume total foi produzido em São Paulo (45,8\%), Paraná (22,3\%) e Santa Catarina (15,9\%). A região sul detém $60 \%$ da produção de papéis de embalagens e, praticamente, a totalidade de papel de imprensa. As empresas localizadas em São Paulo produziram cerca de $75 \%$ do volume de papéis de imprimir e escrever, $61 \%$ dos cartões e $46 \%$ dos papéis sanitários (Macedo e Mattos, 1996). Segundo dados do relatório anual 
da Pulp \& Paper International, o Brasil ocupou, em 1995, o $12^{\underline{0}}$ lugar em produção e o $10^{0}$ no consumo (equivalente a $35 \mathrm{~kg}$ per capita e grande potencial de aumento).

Em termos absolutos, o volume de papel produzido em 1994 no Brasil, nos diferentes segmentos, está apresentado na tabela abaixo. Observa-se um alto grau de especialização das empresas, e a maior importância, em termos de volume de produção, dos papéis de embalagem e imprimir e escrever. Estes volumes de produção sugerem, ainda, a ocorrência de um alto grau de concentração de mercado em todos os segmentos, mas com elevada concorrência no caso dos papéis de embalagem e imprimir e escrever.

Tabela 6 - Principais Produtores de Papel por Categoria - 1994 (em 1000 ton.)

\begin{tabular}{|c|c|c|c|c|c|c|c|}
\hline \multirow[t]{2}{*}{ Grupo } & \multicolumn{2}{|c|}{ Papel de Fibra Longa } & \multicolumn{3}{|c|}{ Papel de Fibra Curta } & \multirow[t]{2}{*}{ Outros } & \multirow[t]{2}{*}{ Total } \\
\hline & Embalagem & Imprensa & Impr./Escr. & Cartão & Sanitário & & \\
\hline Klabin & 598 & 115 & 59 & 3 & 124 & 15 & 914 \\
\hline Suzano & & & 492 & 132 & 10 & & 634 \\
\hline Votorantim & 36 & & 442 & 5 & & 42 & 525 \\
\hline Ripasa & & & 244 & 108 & & 2 & 354 \\
\hline Champion & & & 338 & & & & 338 \\
\hline Igaras & 307 & & & & & & 307 \\
\hline Rigesa & 249 & & & & & & 249 \\
\hline Outros & 1251 & 149 & 250 & 314 & 295 & 74 & 2333 \\
\hline Total & 2441 & 264 & 1825 & 562 & 429 & 133 & 5654 \\
\hline
\end{tabular}

Fonte: Macedo e Mattos (1996)

As tabelas 7 a 10 apresentam a participação das empresas brasileiras nas vendas de papel de imprimir e escrever (tabelas 7 e 8 ) e cartão e cartolina (tabelas 9 e 10) nos mercados externo e interno, respectivamente, nos anos 90 a 95. 


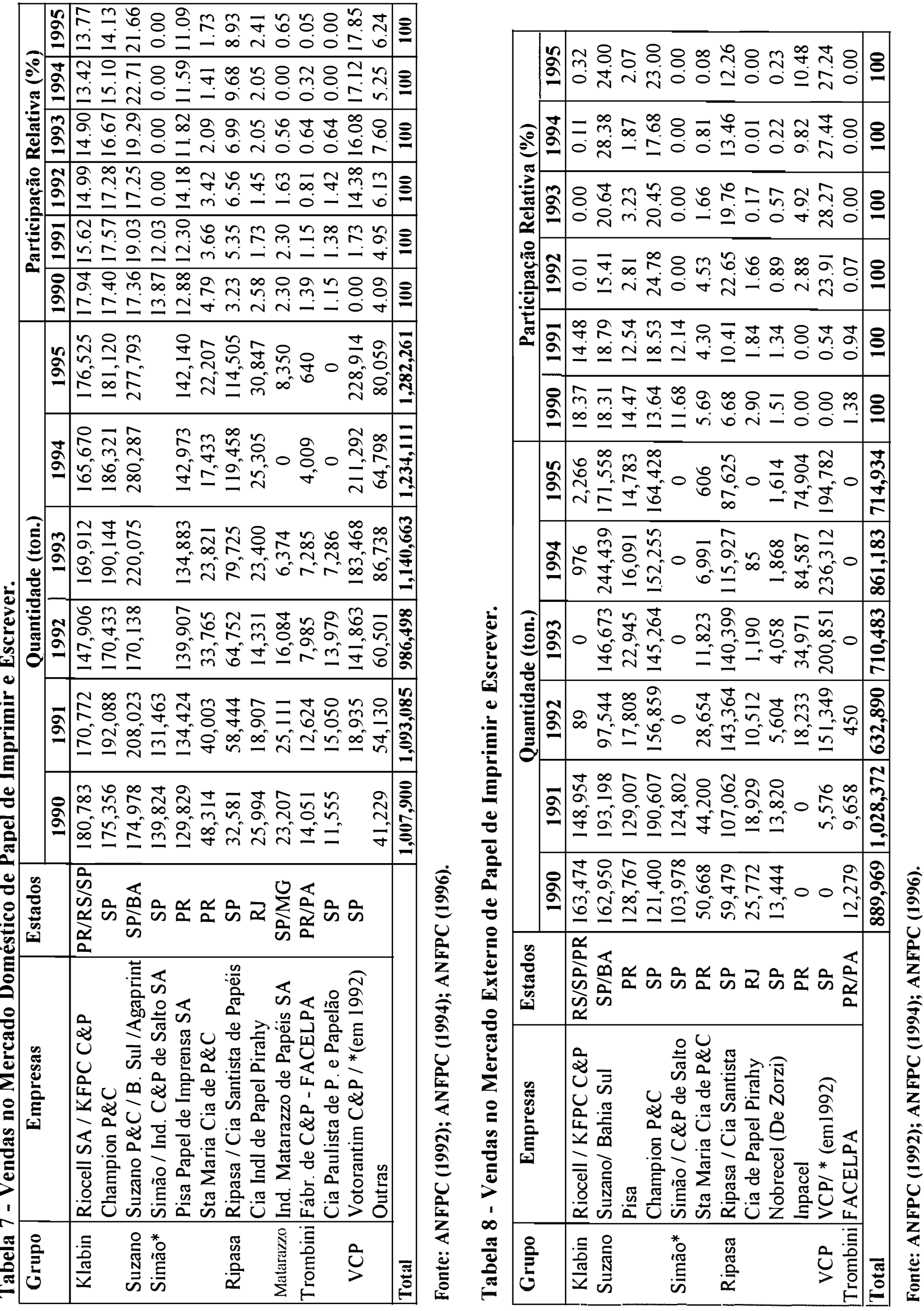




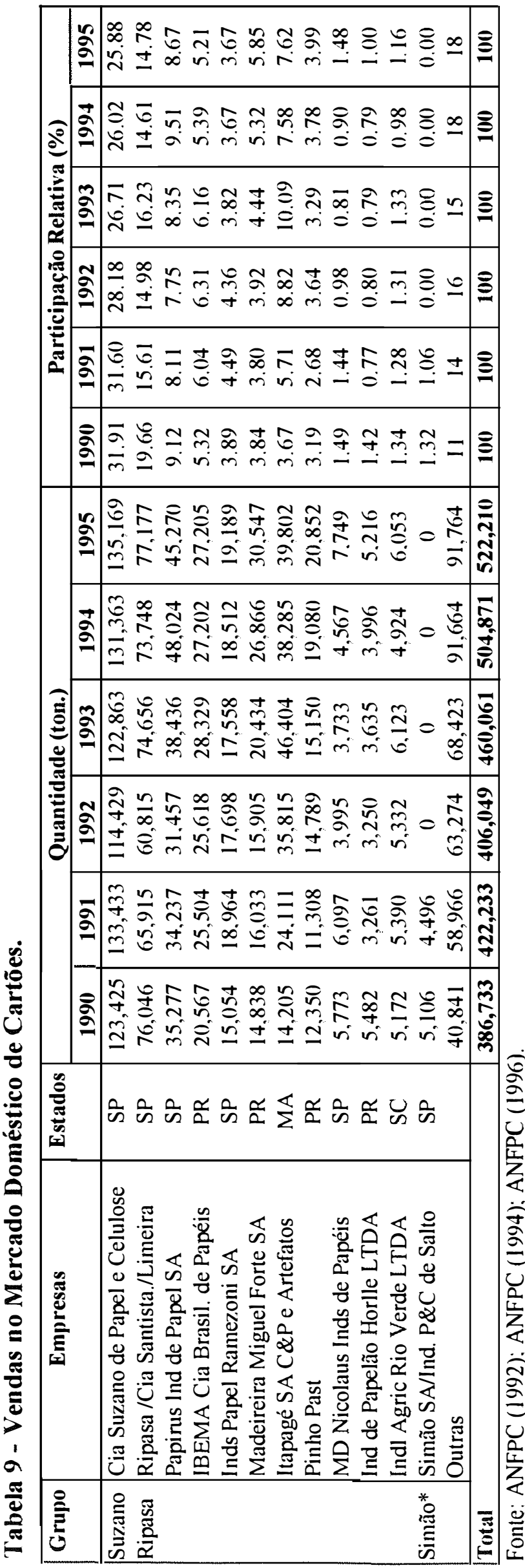

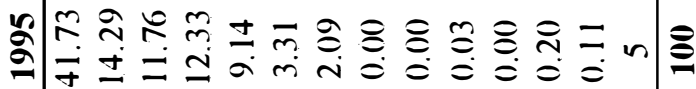

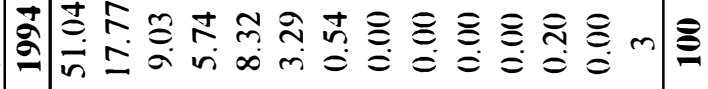

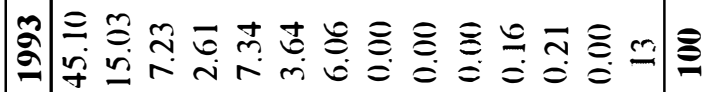

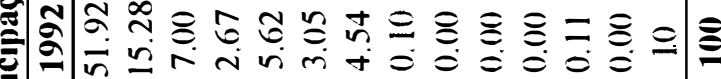

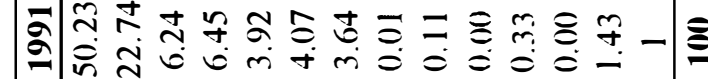

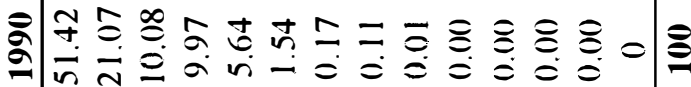

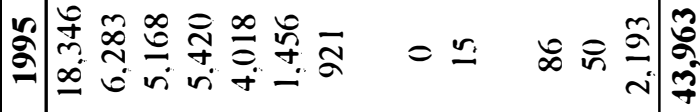

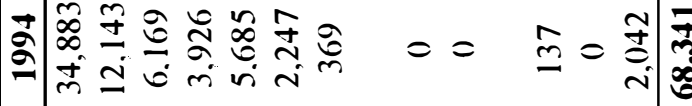

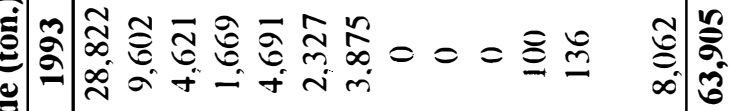

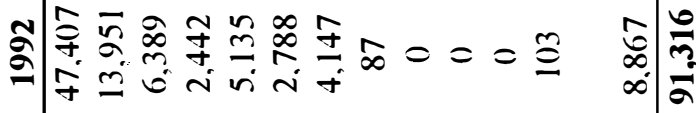

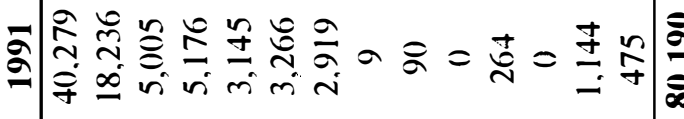

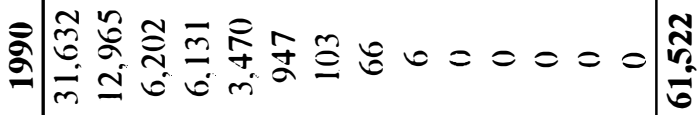

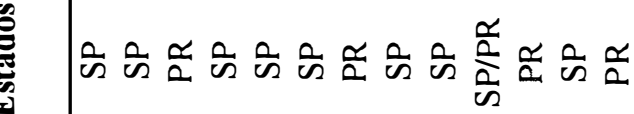

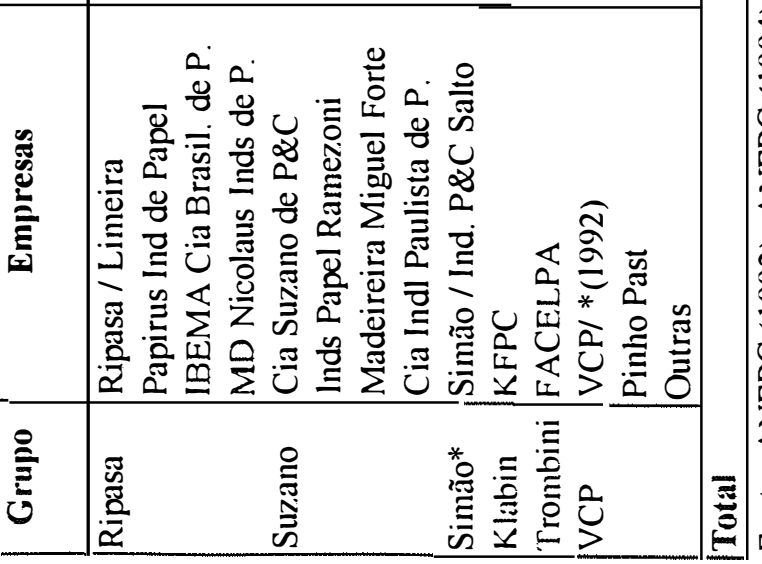


Para uma análise mais acurada do grau de concentração dos mercados domésticos de papel, foram calculados os índices de concentração dos diferentes segmentos de mercado. As tabelas 11, 12 e 13 mostram, respectivamente, os índices de concentração nas vendas de papel de imprimir e escrever, cartão e cartolina e embalagens, no período entre 1990 e 1995.

Observa-se que, de fato, nos três segmentos estudados, o índice CR4 médio é bastante elevado, atingindo no caso do segmento de imprimir e escrever 74,05\%. De forma semelhante ao mercado de celulose, apesar da elevada concentração do mercado, a competição é intensa entre as empresas. O mercado de maior grau de competição entre as empresas é o mercado doméstico de papel para embalagens, onde o índice $\mathrm{HH}$ médio de $6,34 \%$ indica uma distribuição das fatias de mercado de forma equivalente entre as empresas.

Tabela 11 - Índices de Concentração das Vendas de Papel de Imprimir e Escrever

\begin{tabular}{|c|c|c|c|c|c|c|c|c|}
\hline & \multicolumn{6}{|c|}{ Índices de Concentracão } & \multirow[b]{2}{*}{ Média } & \multirow[b]{2}{*}{$\begin{array}{c}\text { Desvio } \\
\text { Padrão } \\
\end{array}$} \\
\hline & 1990 & 1991 & 1992 & 1993 & 1994 & 1995 & & \\
\hline Razão de Concentração - CR4 & 66.57 & 69.98 & 62.54 & 75.76 & 83.70 & 85.76 & 74.05 & 9.36 \\
\hline Hirschman-Herfindahl - I & 13.36 & 14.96 & 12.41 & 17.34 & 21.99 & 22.98 & 17.18 & 4.45 \\
\hline
\end{tabular}

Fonte: Calculado a partir de dados ANFPC (1992), (1994) e (1996)

Tabela 12 - Índices de Concentração nas Vendas de Cartões e Cartolinas

\begin{tabular}{|l|c|c|c|c|c|c|c|c|}
\cline { 2 - 9 } \multicolumn{1}{c|}{} & \multicolumn{7}{c|}{ Índices de Concentração } & \multicolumn{1}{c|}{} \\
\cline { 2 - 10 } \multicolumn{1}{c|}{} & $\mathbf{1 9 9 0}$ & $\mathbf{1 9 9 1}$ & $\mathbf{1 9 9 2}$ & $\mathbf{1 9 9 3}$ & $\mathbf{1 9 9 4}$ & $\mathbf{1 9 9 5}$ & Média & $\begin{array}{c}\text { Desvio } \\
\text { Padrão }\end{array}$ \\
\hline Razão de Concentração - CR4 & 66.02 & 61.36 & 59.73 & 61.37 & 57.72 & 56.95 & 60.53 & 3.25 \\
\hline & & & & & & & \\
\hline Hirschman-Herfindahl - HH & 15.88 & 14.41 & 12.66 & 12.60 & 11.59 & 11.51 & 13.11 & 1.71 \\
\hline
\end{tabular}

Fonte: Calculado a partir de dados ANFPC (1992), (1994) e (1996) 
Tabela 13 - Índices de Concentração nas Vendas de Papel para Embalagens

\begin{tabular}{|l|c|c|c|c|c|c|c|c|}
\cline { 2 - 9 } \multicolumn{1}{c|}{} & \multicolumn{9}{c|}{ Índices de Concentração } & \multicolumn{2}{c|}{} \\
\cline { 2 - 9 } \multicolumn{1}{c|}{} & $\mathbf{1 9 9 0}$ & $\mathbf{1 9 9 1}$ & $\mathbf{1 9 9 2}$ & $\mathbf{1 9 9 3}$ & $\mathbf{1 9 9 4}$ & $\mathbf{1 9 9 5}$ & Média & $\begin{array}{c}\text { Desvio } \\
\text { Padrão }\end{array}$ \\
\hline Razão de Concentração - CR4 & 36.80 & 34.24 & 40.44 & 39.29 & 36.85 & 38.67 & 37.72 & 2.21 \\
\hline & & & & & & & & \\
\hline Hirschman-Herfindahl - HH & 5.75 & 4.94 & 6.56 & 7.50 & 6.69 & 6.59 & 6.34 & 0.88 \\
\hline
\end{tabular}

Fonte: Calculado a partir de dados ANFPC (1992), (1994) e (1996)

Em termos de tendência do período, enquanto o segmento de mercado dos papéis de imprimir e escrever sofreu um aumento da concentração e redução na concorrência, o segmento de cartões passou por um processo inverso e o segmento de embalagens manteve-se constante num patamar de baixa competição e concentração de mercado.

Há, no entanto, uma convergência de estratégias no sentido da especialização, do aumento da capacidade produtiva, modernização industrial, reorganização societária, restruturação administrativa, busca por agregação de valor e internacionalização das atividades e da captação de recursos financeiros. Os grupos nacionais que se estruturaram com essas características são hoje os que se apresentam em melhores condições de acelerar seu crescimento futuro (Macedo e Matos, 1996).

A liderança na área de papel no Brasil é disputada entre os Grupos Klabin, Suzano, e Votorantim. O grupo Suzano partiu para uma agressiva estratégia de parcerias com terceiros (nacionais e internacionais) e, adicionando-se à sua produção, o total produzido pela Igaras em 1994, conclui-se que é, hoje, o maior produtor de papel do país.

O Grupo Votorantim elegeu o segmento de papel e celulose como uma de suas prioridades e tem a seu favor o porte financeiro do conglomerado. Dessa forma, a manutenção da liderança do Grupo Klabin é cada vez mais ameaçada, principalmente se não ocorrerem alterações significativas na sua habitual estratégia (concentração das atividades no mercado interno de papel e celulose, com uma ampla gama de produtos que 
incluem celulose para dissolução e para papel, sacos multifolhados, todos os principais tipos de papéis, além de caixas e acessórios) (Macedo e Matos, 1996).

Indústrias com potencial para rápida elevação das exportações brasileiras sem prejuizo para o suprimento interno, como o de celulose e papel, são de inequívoco interesse nacional. Tais indústrias contribuem para o equilibrio do balanço de pagamentos, sem retrocesso do saudável processo de abertura comercial. Na realidade, a participação da indústria de celulose e papel na geração de divisas transcende ao comércio de suas mercadorias, pois o papel e o papelão são usados para embalar uma série de produtos de exportação (fumo, frutas, peças, manufaturados leves etc.). A tendência é que tanto o papel, como o papelão, sejam ainda mais utilizados, pois o aumento do valor agregado dos produtos exportados implica em maior uso de embalagens (ANFPC, 1995).

$\mathrm{O}$ avanço dos meios eletrônicos de comunicação nos últimos vinte anos não afetou o crescimento do consumo de papel para imprimir e escrever, e nem deve fazê-lo. Segundo relatório publicado pela Associação Nacional dos Fabricantes de Papel e Celulose (1995), estima-se que $95 \%$ de toda a informação armazenada no mundo esteja sob a forma de papel, contra apenas $4 \%$ em microfilme e $1 \%$ em equipamentos eletrônicos. Além deste fato, a difusão de copiadoras, impressoras e aparelhos de fax aumenta significativamente o consumo de papel.

A evolução conjuntural recente do cenário mundial reforça projeções favoráveis à indústria de celulose e papel. A recuperação econômica das economias americanas, européia e japonesa levou o FMI e o Banco Mundial a preverem uma expansão de 3\% a.a. para os países industrializados durante o período entre 1995 e 2000. Estas projeções também indicam crescimento de $5,6 \%$ a.a. para os países em desenvolvimento de forma que a projeção de crescimento para a economia mundial é de $3,3 \%$ a.a. O consumo mundial de celulose e papel deve evoluir neste mesmo ritmo e pode ser ainda maior caso ocorram altas taxas de crescimento no consumo dos países em desenvolvimento da 
América Latina, leste asiático e leste europeu. Em alguns segmentos de mercado pode haver aumento real de vendas de 15\% no biênio 1995-96 (ANFPC, 1995).

Por trás deste crescimento, a exigência de multiplicidade de novos produtos e processos produtivos ambientalmente adequados alteraram os padrões de tecnologia, marketing e qualidade. As empresas líderes utilizam padrões internacionais de qualidade de produtos, cada vez mais estritos e exigentes. Atualmente, as especificações de qualidade transcendem o produto em si e atingem todo o processo de produção, distribuição e assistência técnica (reforçando a relevância da certificação ISO). No Brasil, quatorze empresas do setor obtiveram a certificação ISO-9000: Aracruz, Bahia Sul, Cenibra, Pirahy, Jari, Rigesa, VCP (Votocel e Luiz Antonio), Champion, Riocell, Inpacel, Igaras e Klabin (KFPC e Santa Therezinha). Também são crescentes as restrições aos processos que agridam o meio ambiente, tanto nos países desenvolvidos como no Brasil. A consciência ecológica estimula o rigoroso controle da emissão de efluentes, resíduos e odores, e o aumento da reciclagem, e uso de processos de branqueamento da celulose livres de cloro molecular ${ }^{9}$.

Além da necessidade de permanente atualização tecnológica, a globalização da economia mundial, associada à abertura do mercado brasileiro, internacionalizou a concorrência, pressionando as empresas à eficiência produtiva e agilidade gerencial. Este novo ambiente, composto também pelo fim dos Incentivos Fiscais ao Reflorestamento, corresponde à principal justificativa para o desenvolvimento deste trabalho, que se utilizará dos conceitos teóricos apresentados a seguir.

\footnotetext{
${ }^{9}$ A Alemanha exige celulose livre de cloro (TCF - Total Chlorine Free) e Inglaterra e França exigem celulose sem cloro elementar (ECF - Elementar Chlorine Free). Os mercados asiáticos. latinoamericanos. africanos e norte-americanos não fazem este tipo de exigência.
} 


\section{Referencial Teórico: A ECONOMIa dos Custos de TransaÇão}

\subsection{Contextualizando o surgimento da ECT}

$\mathrm{Na}$ primeira seção deste capítulo descreve-se o surgimento da Economia dos Custos de Transação (ECT) a partir de uma vertente de pesquisa da Nova Economia Institucional, que compartilha com outras escolas os conceitos de agribusiness.

Historicamente, o termo agribusiness teve origem em 1957, no trabalho de John Davis e Ray Goldberg, ambos da Universidade de Harvard. Para estes pesquisadores, o conceito de agribusiness é:

“...o conjunto das operações de produção, armazenamento, distribuição e comercialização de insumos e produtos agricolas e seus derivados. "

A idéia de Davis e Goldberg era a de que os problemas relacionados com o setor agroalimentar e de produção de fibras vegetais transcendem a atividade rural. Isto porque a eficiência de cada operação pertencente a um sistema produtivo depende, em última análise, da eficiência de todas as operações envolvidas. Não é suficiente que um produtor seja extremamente eficiente na sua atividade, caso seu produto seja deteriorado no transporte. Ou ainda, de nada adianta uma produção agrícola exemplar, se o mercado perdeu o interesse no produto oferecido. Portanto, a análise dos problemas relacionados com o setor agroalimentar e de produção de fibras vegetais deve contemplar todos os segmentos envolvidos direta ou indiretamente à produção rural.

Com esta visão, um citricultor de Bebedouro, por exemplo, tem que estar preocupado em ser individualmente o mais eficiente possivel em termos de produtividade (caixas/pé) e custos, mas também tem que estar preocupado com atributos de qualidade de fruta 
desejados pelas indústrias, tendências do consumo de suco nos países europeus, EUA, Japão e tigres asiáticos, situação das empresas de insumos, barreiras não tarifárias relativas à sanidade e resíduos, entre outros. Deve preocupar-se com a saúde da sua empresa e de seu sistema (Neves, 1995).

A visão sistêmica da atividade agropecuária permite uma melhor compreensão do seu funcionamento e é indispensável nos setores público e privado. Normalmente, esta decisão está vinculada a um determinado setor, ou a um produto específico. Neste caso, a análise restringe-se a um fluxo de produção caracterizado desde a pesquisa até o consumidor final, chamado de Sistema Agroindustrial (SAG).

O termo SAG, assim como agribusiness, foi conceituado originalmente em Harvard, por Davis e Goldberg (1957), como:

"Sistema que envolve as atividades de produção, armazenamento, processamento, marketing e comercialização de um produto agricola especifico, dos insumos para produzi-lo e de seus derivados, além das instituições que afetam e coordenam os estágios sucessivos do fluxo do produto, tais como Governo, Associações e mercados futuros."

Segundo Zylbersztajn (1995), apesar da concepção de agribusiness representar uma importante ferramenta de análise, esta peca por não explicitar relações causais entre os agentes e a coordenação do sistema, inviabilizando a formulação de hipóteses. Crítica semelhante é apontada por Shelman (1991) ao afirmar que há uma tendência dos estudos dos sistemas agroindustriais limitarem-se a relatos meramente descritivos.

Apesar das críticas levantadas, Zylbersztajn (1995) aponta a concepção de agribusiness como parte daquela desenvolvida pela economia institucional. Ambas escolas aceitam a hipótese fundamental da análise institucionalista, de que as instituições não são neutras no 
processo de coordenação das cadeias produtivas. Adicionalmente, dado que a coordenação dos sistemas agroindustriais é feita via contratos, o conceito de agribusiness fica ainda mais próximo da Nova Economia das Instituições. Estas referências remetem ao trabalho seminal de Coase (1937), que definiu a empresa como "um complexo de contratos coordenados centralmente, com o objetivo de economizar em custos de transação".

A aproximação entre o Agribusiness proposto em Harvard e a Nova Economia das Instituições (NEI) representa um significativo avanço conceitual sobre a análise descritiva. Cada elo do sistema agroindustrial passa a poder ser estudado através de relações contratuais sob a ótica da eficiência. A teoria proposta na Nova Economia das Instituições, em particular na Economia dos Custos de Transação, tornou-se uma importante ferramenta de análise do problema de coordenação vertical de Sistemas Agroindustriais.

O surgimento e consolidação da NEI foi detalhadamente analisado por Azevedo (1996). Segundo este autor, as principais contribuições para a primeira etapa deste processo surgiram em meados de 1930, nos trabalhos de Coase, Commons, Knight, Barnard e, posteriormente Hayek.

Para Azevedo (1996), o mérito de Commons é ter sugerido que se tome a transação como unidade de análise, em um momento em que a firma era vista como uma entidade indivisível. A Knight o autor atribui o mérito de ter afirmado que o principal motivo para se entender as organizações econômicas é o propósito de redução do desperdício. A Barnard e Hayek coube levantar a questão da adaptação às mudanças no ambiente econômico como o principal problema econômico, em um momento em que se dava ênfase a exercícios de estática comparativa. 
É a Coase, no entanto, que Azevedo (1996, p.11) atribui a mais importante contribuição ao desenvolvimento da NEI - a explicação de como se dá a gênese da firma:

\begin{abstract}
"Até então a firma era vista somente como a instância na qual uma ou várias transformações tecnológicas eram processadas em um determinado bem ou serviço. Aspectos organizacionais ou de relacionamento com clientes $e$ fornecedores eram sumariamente ignorados, de tal modo que a firma podia ser representada como uma Função de Produção, cujas entradas são os vários insumos necessários à produção e as saidas os produtos produzidos por ela...Coase divisou que a...coordenação do sistema econômico poderia se realizar internamente à firma... (que) não seria, portanto, somente um espaço para a transformação do produto. mas também um espaço para a coordenação das ações dos agentes econômicos alternativo ao já estudado mercado."
\end{abstract}

Na NEI as organizações são definidas como um conjunto de contratos que funcionam como elos das cadeias produtivas. Estes contratos variam em complexidade, podendo ser apresentados formalmente, por escrito, em inúmeras laudas, num texto detalhando salvaguardas e regras a serem cumpridas, ou ainda, podendo ser a simples relação de fidelidade de um consumidor com uma marca (Neves, 1995). As interligações entre etapas produtivas tecnologicamente separáveis, estabelecidas pelos contratos, são as transações.

Ainda segundo Azevedo (1996), Coase centra sua análise em duas formas abstratas de coordenação: mercado e firma, embora reconheça que as formas intermediárias a tais extremos sejam as mais comuns na coordenação do sistema econômico. Nesta análise, Coase explica que a coexistência das diferentes formas de coordenação (via mercado, verticalização e arranjos contratuais intermediários) ocorre porque os custos de utilização de uma ou outra forma diferem. Tais custos são de natureza distinta daqueles incorridos na produção (vinculados à tecnologia empregada), e por isso foram denominados de custos de transação, dado que relacionam-se à forma como se processa uma transação. 
Assim, os custos de produção correspondem à soma dos custos de transação e dos custos de transformação ${ }^{10}$.

Os custos de transação correspondem basicamente aos custos da informação e aos custos de execução contratual (North, 1992). Os custos de transação ex-ante, incorridos antes da ocorrência da transação, dizem respeito à elaboração do contrato. Mesmo no caso de contratos verbais, há sempre um custo de negociação. Os custos ex-post são aqueles referentes ao incentivo e monitoramento dos agentes para a consumação da transação dentro dos termos contratados, além dos eventuais custos de renegociação por má adaptação das partes envolvidas. De acordo com as definições apresentadas, Cheung $(1990)^{11}$, citado por Azevedo (1996), define custos de transação como os custos de a) elaboração e negociação dos contratos, b) mensuração e fiscalização de direitos de propriedade, c) monitoramento do desempenho e d) organização das atividades. A estes custos Azevedo (1996) adiciona os custos de adaptações ineficientes às mudanças do sistema econômico.

Segundo North (1992), "mesmo o exame mais superficial de uma economia sugere ao observador que muitos dos agentes econômicos - na verdade, a maioria - não produzem nada do que os indivíduos consomem. Mas, advogados, banqueiros, contadores, funcionários de escritórios, gerentes e políticos, para citar apenas algumas das ocupações ampla ou totalmente envolvidas em transações, são peças essenciais ao funcionamento de qualquer sistema econômico. Na verdade, quanto mais complexa a economia, mais atores desse tipo estarão envolvidos na coordenação e operação do sistema". É o que demonstra o trabalho de Wallis e North (1986), citado por North (1992), onde estimou-se que o

\footnotetext{
${ }^{10}$ Azevedo (1996) define custos de transformação como aqueles incorridos na transformação de fatores de produção em produto(s). desconsiderando-se a necessidade de adquirir-se tais fatores ou de vender os produtos.

${ }^{11}$ CHEUNG. S. (1990) On the New Institutional Economics Cheung, S. et alii Contract Economics, 48-75p.
} 
"setor de transações" da economia norte-americana tenha sido responsável por $45 \%$ do PNB em 1970.

A estrutura do argumento de Coase para relacionar os custos de transação às formas organizacionais foi formalizada por Masten (1994), como se segue. Dados dois arranjos institucionais alternativos G1 e G2, associados aos custos de transação C1 e C2, respectivamente, o arranjo mais eficiente será aquele de menor custo.

A proposição original de Coase, relacionando a forma organizacional aos custos de transação, repercutiu modestamente na literatura econômica, particularmente em estudos empíricos, na medida em que não se tratava de uma hipótese refutável, dada a impossibilidade de mensuração dos custos de transação (Azevedo, 1996). Segundo Masten (1994), o principal problema do modelo de Coase, além da dificuldade de mensuração do próprio custo de transação, é a impossibilidade de observação (mensuração) dos custos de transação nas formas organizacionais não escolhidas.

As idéias fundamentais de Coase foram amadurecidas, em parte modificadas e reunidas para formar um corpo teórico coerente. Nesse sentido, surge a importante contribuição de Williamson (1985), que contou com a colaboração de diversos autores na consolidação da $\mathrm{NEI}^{12}$. Paralelamente, outros trabalhos foram desenvolvidos, fazendo surgir novas vertentes de pesquisas, preocupadas em solucionar diferentes questões. Dentre estas, destacaram-se duas vertentes complementares: a do Ambiente Institucional e a das Instituições de Governança (Williamson, 1991a). A seguir, serão apresentadas as características que distinguem e complementam estas vertentes, para depois detalhar a vertente das Instituições de Governança (ou Economia dos Custos de Transação) que será utilizada como suporte teórico no presente trabalho.

\footnotetext{
${ }^{12}$ Entre esses. destacam-se Douglas North. liderando a pesquisa sobre Ambiente Institucional, e de Paul Joskow, em aplicações empíricas (Azevedo, 1990).
} 
Para Azevedo (1996), a complementaridade das vertentes reside no objeto de análise comum - a economia com custos de transação - na qual o quadro institucional ocupa uma posição de destaque no resultado econômico. A distinção destas duas vertentes reside no nível da análise desenvolvida. Enquanto os trabalhos no campo do Ambiente Institucional tem um caráter macro, como o estudo da legislação de um país, no campo das Instituições de Governança (ou Arranjo Institucional) este caráter é micro, pois são estudados os regimentos internos de empresas (Williamson, 1994). É o que define o trabalho de Davis \& North $(1971,6)$, citado por Azevedo (1996):

"The institutional environment is the set of fundamental political, social and legal ground rules ${ }^{13}$ that establishes the basis for production. exchange and distribution. Rules governing elections, property rights, and the right of contract are examples of this type of ground mules that make up the economic environment. [...]

The institutional arrangement is an arrangement between economic units that govern the ways in which this units can cooperate and / or compete ${ }^{14}$. It must [...] be designed to accomplish at least one of the following goals: to provide a structure within which its members can cooperate to obtain some added income that is not available outside that structure: or to provide a mechanism that can effect a change in laws or property rights designed to alter the permissible ways that individuals (or groups) can legaly compete".

A forma como os dois níveis de análise relacionam-se foi apresentada esquematicamente por Williamson (1993), como na figura abaixo.

\footnotetext{
${ }^{13}$ São as "regras do jogo", como North costuma definir.

${ }^{14}$ São os "jogadores" ou agentes econômicos.
} 


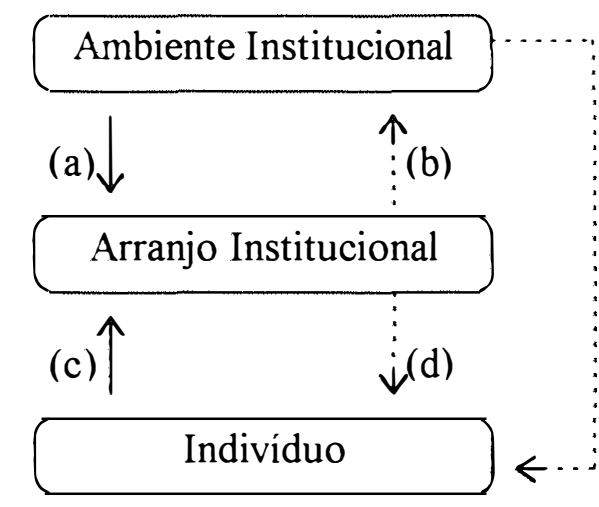

\section{Figura 7 - Relações entre Arranjo e Ambiente Institucional. Fonte: Williamson (1993)}

O componente principal da relação entre arranjo e ambiente institucionais foi indicado por (a). Este exprime como as regras do jogo condicionam o aparecimento e a seleção das formas organizacionais, na composição de um arranjo institucional. Segundo North (1992), as limitações impostas pelo contexto institucional (ao lado de outras restrições normais de qualquer economia) definem o conjunto de oportunidades e, portanto, o tipo de organizações que serão criadas.

Por exemplo, a garantia mais incisiva de direitos de propriedade ${ }^{15}$ é capaz de reduzir a incerteza implícita às transações, o que, por sua vez, altera a eficiência relativa de diferentes formas organizacionais, modificando o arranjo institucional eficiente (Azevedo, 1996). A inexistência da lei de proteção de cultivares no Brasil, e portanto a indefinição dos direitos de propriedade sobre o material genético melhorado, desestimula a entrada de empresas nesse tipo de mercado. Outro exemplo da relação entre ambiente e arranjos institucionais foi o estabelecimento de incentivos fiscais ao reflorestamento pelo governo brasileiro na década de 70. Como será discutido em detalhes no decorrer deste trabalho, tais incentivos consistiram num forte sinalizador para a escolha de um arranjo institucional do tipo hierárquico pelas empresas produtoras de papel e celulose.

\footnotetext{
${ }^{15}$ Direitos de propriedade são aqueles que definem o uso, a renda potencial e a alienação dos bens (North. 1992).
} 
Assim, as instituições não são "elementos neutros" com respeito à alocação de recursos na economia, interferindo nos custos de transação (Jank, 1996) e na direção da evolução do arranjo institucional (North, 1992).

Voltando à figura acima, o efeito indicado por (b) exprime a capacidade de alteração do ambiente institucional por parte das organizações. É o caso das ações de grupos de pressão, ou lobbies setoriais, na busca por mudanças na legislação que resultem em beneficios para seus grupos. Este efeito não é, no entanto, foco de análise da NEI. Assim como não o são os efeitos (d), que segundo Williamson (1993) exprimem o efeito do ambiente e do arranjo institucionais sobre as preferências "endógenas" dos indivíduos.

Representado por (c) está o papel dos indivíduos no estabelecimento dos arranjos institucionais. A complexidade das organizações e a limitação cognitiva dos agentes econômicos, frequentemente geram desperdícios e custos desnecessários durante o estabelecimento e a vigência dos arranjos institucionais (Williamson, 1991b). Segundo North (1992), a informação, necessária à redução dos custos de transação, não só é cara como incompleta e o cumprimento de contratos não só é caro, como imperfeito. Dada a aspiração da NEI de captar a organização como ela é, e portanto considerando estas falhas, foram estabelecidas duas pressuposições básicas acerca do comportamento dos agentes: racionalidade limitada e oportunismo.

Williamson (1985) classificou a racionalidade em três níveis: racionalidade forte, semiforte (ou limitada) e fraca. Essa classificação não esgota os possiveis modelos de racionalidade dos agentes, que poderiam incluir a irracionalidade, por exemplo, mas abrange os principais modelos de racionalidade empregados na teoria econômica (Azevedo, 1996). 
No primeiro nivel de racionalidade, definido por Williamson (1985) como forte, os agentes têm perfeito conhecimento de todas as informações disponiveis e são capazes de processá-las de forma a maximizar seu objetivo, seja ele utilidade, lucro, receita ou qualquer outro. É sobre esse tipo de racionalidade que o pensamento econômico ortodoxo baseia-se, fundamentalmente por permitir a formalização rigorosa de seus modelos.

O segundo nivel de racionalidade é utilizado pela NEI como um dos pressupostos comportamentais dos agentes. O conceito de racionalidade limitada foi inicialmente desenvolvido por Simon (1961) citado por Jank (1996) e corresponde à capacidade restrita de processamento de informações, apesar da busca por objetivos maximizadores. Segundo Azevedo (1996), o pressuposto de racionalidade limitada implica que o agente por exemplo, um empresário - se empenhará em obter o máximo lucro para sua empresa, no entanto, a obtenção de informações necessárias às decisões que levem a esse objetivo, assim como a capacidade de processamento de contratos complexos que dêem conta de todas as contingências, são limitadas ou, na melhor das hipóteses, custosas. Assim, em vez da decisão ótima, o agente contenta-se com uma alternativa satisfatória, e indistinguivel dentre tantas igualmente satisfatórias, devido aos limites da racionalidade.

O terceiro, e último, nivel de racionalidade assume que a capacidade racional dos indivíduos não é suficiente para direcionar a escolha de um quadro institucional com a finalidade de amenizar problemas contratuais ex-post. O modo pelo qual os agentes enfrentam as contingências não previsiveis é o estabelecimento de rotinas, que nem sempre se traduzem em uma resposta racional (estratégica) à situação que se defronta o indivíduo (Azevedo, 1996).

O segundo pressuposto comportamental assumido pela NEI é o de oportunismo. De forma semelhante à classificação da racionalidade, Williamson (1985) identifica três niveis decrescentes de oportunismo. No primeiro nivel, identificado como "self-interest seeking 
with guile", o egoísmo dos agentes é irrestrito, sendo possível a ocorrência de trapaças e mentiras, tanto antes da realização da transação (oportunismo ex-ante), como durante a vigência do contrato (oportunismo ex-post) ${ }^{16}$.

O segundo nível de oportunismo é aquele utilizado nos modelos econômicos ortodoxos, onde pressupõem-se o cumprimento fiel das cláusulas contratuais. Apesar da índole egoísta dos agentes, a eficiência do sistema judicial, a inexistência de custos de transação e/ou a ética seriam suficientes para garantir o cumprimento dos contratos.

O terceiro nível de oportunismo é utilizado nas formulações utópicas de engenharia social e para servo-mecanismos, onde as ações individuais são comandadas por uma entidade externa ao próprio indivíduo, como o governo ou ideologia (Azevedo, 1996).

Segundo Williamson (1991b) as principais consequências dos pressupostos comportamentais de limitação cognitiva e oportunismo são:

1. todos os contratos são incompletos e muitos processos complexos de organização das transações deixam de ser utilizados em função da racionalidade limitada dos agentes;

2. a credibilidade de um contrato não é total em função do comportamento oportunístico dos agentes;

3. ganhos de eficiência nas transações serão conseguidos com a redução da limitação da racionalidade e com a inclusão de salvaguardas capazes de reduzir os riscos de oportunismo.

\footnotetext{
${ }^{16}$ Azevedo (1996) explica a distinção temporal do oportunismo através dos conceitos de moral hazard (ação oportunística ex-post) e seleção adversa (ação oportunística ex-ante). Ambos fenômenos ocorrem na presença de racionalidade limitada e. principalmente. de assimetria informacional entre as partes envolvidas. A detenção de informações privilegiadas sobre a transação é o fator que permite a ação oportunística em beneficio próprio.
} 
Nas palavras de Azevedo (1996):

"A importância do pressuposto comportamental de oportunismo está na possibilidade de surgimento de problemas de adaptação decorrentes da incompletude dos contratos. A racionalidade limitada implica contratos incompletos e consequentemente, renegociações futuras. $O$ oportunismo implica que as partes podem se aproveitar de uma renegociação, agindo aeticamente e, por consequência. impondo perdas à(s) sua(s) contraparte(s) na transação".

De fato, como colocam Furubotn e Richter (1994) citados por Azevedo (1996, p.49), a nova literatura institucionalista reconhece que na ausência de racionalidade limitada e comportamento oportunista, todos os problemas econômicos relativos à contratação seriam triviais. Nesse caso, não haveria necessidade de se estudar instituições econômicas. É dentro deste contexto que Williamson (1991a) define o problema da escolha de formas organizacionais mais eficientes:

“...assess alternative governance structures in terms of their capacities to economize on bounded rationality while simultaneously safeguarding against opportunism."

Esta definição mostra o caminho trilhado por Williamson, entre outros autores no rumo da vertente das Instituições de Governança, sua principal linha de trabalho. Para a melhor compreensão do relacionamento entre as duas vertentes da NEI, Ambiente Institucional e Instituições de Governança, a análise do quadro conceitual desenvolvido por Joskow (1995) se faz interessante. Este quadro, complementado por Jank (1996), está apresentado a seguir. 


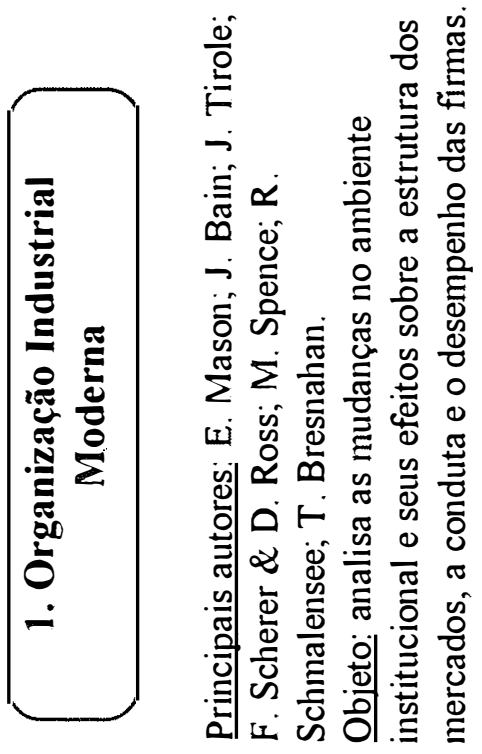


Na figura acima, além das duas vertentes da NEI já mencionadas, Joskow (1995) incluiu o ramo de pesquisa da Organização Industrial Moderna para contextualizar, de forma mais abrangente, o estudo da organização e do desempenho dos mercados. O presente trabalho utilizará como principal suporte teórico a vertente das Estruturas de Governança, também conhecida como Economia dos Custos de Transação (ECT), e por isso, a seguir, serão apresentadas as características básicas desta teoria.

\subsection{Conceitos Fundamentais da Economia dos Custos de Transação}

Oliver Williamson, da Universidade de Berkeley - Califórnia, é reconhecido como o principal formalizador dos conceitos da Economia dos Custos de Transação (ECT). Sua grande contribuição à teoria em relação à proposição de Coase, apresentada anteriormente, foi explicar a diversidade contratual através dos atributos das transações. Para Williamson (1985), tais atributos são os elementos explicativos dos custos de transação e, por serem observáveis, permitem a formulação de hipóteses acerca da determinação dos arranjos institucionais mais eficientes. "Os elementos observáveis (atributos da transação) permitiriam deduzir o nivel de custos de transação e qual seria a forma organizacional eficiente para reger essa determinada transação (Azevedo, 1996)."

A decisão entre comprar ou fazer, além de tocar a essência da economia dos custos de transação, traz à tona interessantes questões sobre estratégia empresarial (Williamson, 199lb). Para o autor, na verdade, a grande estratégia é a própria economia, a racionalização do uso dos recursos.

Para Williamson $(1975,1986)$ e Klein, Crawford e Alchian (1978), citados por Lieberman (1991), os incentivos à integração vertical surgem da ocorrência de problemas ex-ante (pequeno número de firmas no mercado) ou ex-post (investimentos específicos que vinculam as partes envolvidas na transação). Neste último caso, cada parte tem a 
possibilidade de apropriar-se de quase-rendas advindas dos investimentos feitos pela outra empresa. Assim, as partes entram num relacionamento de dependência bilateral baseado na ocorrência de ativos específicos. Desta situação resulta um contrato de longo prazo (caso seja possivel a elaboração de contratos com salvaguardas para as partes) ou então ocorre a integração das firmas.

Imperfeições de mercado de vários tipos podem criar incentivos para as firmas integrarem-se verticalmente. Estudos teóricos têm mostrado que a integração vertical pode ser induzida por custos de transação, competição imperfeita, economias de escala, vantagens fiscais, entre outros fatores (Lieberman, 1991 e Williamson, 1991). Apesar desta infinidade de determinantes da escolha entre integração vertical, a economia dos custos de transação focaliza os atributos das transações como os fatores fundamentais e busca avaliar quais estruturas de governança são mais aptas para organizar cada transação e porque (Williamson, 1991). De fato, diversos estudos empíricos têm apontado os custos de transação como fatores determinantes da integração e têm encontrado fortes evidências para corroborar a teoria dos custos de transação. Incluem-se nos exemplos deste tipo de estudo os trabalhos de Lieberman (1991), Neves (1995), Ohanian (1994), Globerman e Schwindt (1986), Muris, Scheffman e Spiller (1992), entre outros.

Segundo os conceitos da ECT, o grau de integração será uma decorrência dos atributos das transações (especificidade dos ativos, freqüência e risco), bem como dos parâmetros ditados pelo ambiente institucional onde a firma está inserida. Assim, nem sempre a solução de integração é a melhor. Uma análise das condições especificas nas quais a firma opera apontará a melhor forma de conduzir a produção, seja ela interna (verticalizada), via mercado ou através de estruturas mistas entre mercados e interna, que caracterizam as inúmeras formas contratuais como associações estratégicas, franquias, contratos de distribuição, entre outras (Zylbersztajn, 1995). 
Segundo a Teoria dos Custos de Transação, as formas organizacionais mais eficientes são aquelas que minimizam além dos custos de transformação, os custos de transação, e que apresentam maior capacidade de adaptação às mudanças institucionais. Nas palavras de Williamson (1991b), a hipótese básica da economia dos custos de transação é a de que a eficiência das organizações é dada pelo alinhamento entre as transações (que diferem em seus atributos) e as estruturas de governança (que diferem em seus custos e capacidade de minimizar os custos de transação), para um dado ambiente institucional.

A capacidade de adaptação das organizações a novos ambientes institucionais, ou seja, a coordenação dos sistemas produtivos, está diretamente relacionada com o conceito de competitividade adotado por vários autores. Farina e Zylbersztajn (1994) argumentam que a coordenação é, de fato, um dos elementos fundamentais na determinação da competitividade. Nas palavras destes autores: "sistemas competitivos serão aqueles que conseguirem aliar estruturas tecnológicas eficientes (no sentido de custos mínimos de produção e escalas ótimas), com estruturas de governança economizadoras de custos de transação. Este conceito, que também foi utilizado por Jank (1996) e Streeter, Sonka e Hudson (1991), será adotado no presente trabalho para analisar o sistema agroindustrial da celulose.

\section{Modelagem da escolha da forma organizacional}

De acordo com a ECT, o modelo de escolha da forma organizacional baseia-se nos custos e nos atributos de uma transação. Tais atributos são três: especificidade dos ativos envolvidos na transação, frequência de ocorrência da transação e risco associado à transação. 


\section{Especificidade do Ativo}

A especificidade do ativo transacionado é considerado o mais importante indutor da forma de governança. Especificidade do ativo é o grau de especialização de um investimento, que está diretamente relacionado com a dificuldade de alocação do recurso em usos alternativos. Assim, ativos específicos são aqueles que ao serem empregados em um uso alternativo ao original sofrem perdas de valor.

A especificidade de um ativo, aliada aos pressupostos comportamentais de oportunismo e ao fato dos contratos serem incompletos, torna o investimento em tal ativo sujeito a riscos e problemas de adaptação, gerando custos de transação (Azevedo, 1996). É fundamental ressaltar que tais pressupostos comportamentais são condições necessárias para que o investimento em ativos específicos torne-se um problema econômico. Segundo Azevedo (1996), não havendo limites a capacidade cognitiva, os agentes poderiam resolver ex-ante, através de um contrato completo, os problemas de dependência entre os agentes criados pela especificidade de ativos. Da mesma forma, na ausência de oportunismo, as partes não se aproveitariam dos contratos incompletos de modo aético, o que evitaria perdas às suas contrapartes.

Como os ativos específicos possuem um maior valor quando empregados na transação à qual são especificos, gera-se uma quase-renda na transação em questão. A quase-renda, nesse contexto, é definida como a diferença entre o retorno de um ativo empregado em uma transação especifica e seu retorno em um emprego alternativo. Esse montante é objeto de barganha entre as partes envolvidas na transação, na medida em que a sua geração depende da continuidade do negócio (Azevedo, 1996). Por isso, transações envolvendo ativos especificos tendem a desenvolver situações de dependência bilateral entre os agentes, onde dada a pressuposição do comportamento oportunístico, há a possibilidade de ambos os agentes exercerem poder monopolístico sobre as quase-rendas. Cada uma das partes tentará se apropriar do ganho gerado pelo investimento específico, 
gerando conflitos e problemas de adaptação, ou seja custos de transação (Williamson, 1985).

Williamson (1991a) identifica seis tipos de especificidade de ativos: 1) especificidade locacional (diz respeito à localização relativa de firmas responsáveis por etapas sucessivas da mesma cadeia produtiva, favorável à economia de despesas com armazenagem e transporte); 2) especificidade de ativos fisicos (refere-se às características fisicas inerentes ao produto transacionado cujo uso é específico, por exemplo uma forma para produzir um componente); 3) especificidade de ativos humanos (relativa à experiência profissional adquirida); 4) especificidade de marca (referente ao capital que se materializa no nome de um produto ou empresa); 5) ativos dedicados (diz respeito a investimentos realizados para um cliente em especial, a quem se restringe a utilidade de tais investimentos) e 6) especificidade temporal (referente ao investimento para garantia de ganho no tempo em que se processa a transação, particularmente importante no caso de produtos perecíveis).

Segundo Azevedo (1996) do ponto de vista teórico, a ECT não distingue os efeitos das diferentes especificidades, o que permite que o mesmo arcabouço teórico seja usado para todos os tipos de especificidade.

Williamson (1991a) relaciona a especificidade de ativo com a escolha da forma organizacional responsável pelo governo dessa transação. Cada forma organizacional apresenta diferentes níveis de controle sobre uma transação; como exemplo, a transação entre firmas intermediadas pelo mercado apresenta um grau de controle menor do que aquele verificado entre firmas intermediadas por um contrato de longo prazo. O mesmo pode ser dito da transação via contratos em relação à integração vertical. Dado que as diferentes formas organizacionais apresentam um nivel distinto de controle sobre uma transação, cada uma delas lida diferentemente com a ação oportunista e seus custos em uma transação que empregue ativos específicos. 
Assim, quanto maior a especificidade dos ativos, maiores as quase-rendas geradas, maior

a necessidade de controle sobre a transação e, portanto, ceteris paribus, maior a tendência à integração vertical. Por outro lado, ativos de baixa especificidade podem ser realocados para outra transação com baixo custo associado a ações oportunísticas, devendo ser preferencialmente transacionados no mercado.

\section{Frequência da Transação}

O segundo atributo da transação, relevante para a escolha da forma organizacional, é a frequência da transação. Segundo Azevedo (1996) a importância desta dimensão da transação manifesta-se em dois aspectos: a possibilidade de diluição dos custos de adoção de um mecanismo complexo de controle por várias transações e a possibilidade de construção de reputação por parte dos agentes envolvidos.

Quanto maior a freqüência em que dada transação ocorre, maior é a possibilidade de internalizar a etapa produtiva da transação em questão, sem perder eficiência relacionada à escala. Uma transação realizada esporadicamente não justifica o estabelecimento de relações contratuais de longo prazo, ou mesmo da verticalização, mas a necessidade constante de realização da transação pode justificar a internalização desta etapa produtiva.

A freqüência da transação também é importante na identidade entre os agentes e no estabelecimento de relações de confiança que estimulam uma fidelidade comercial. Segundo Azevedo (1996), a relação continuada permite que se conheçam as idiossincrasias de cada parte, tornando o resultado da transação mais previsivel. Neste aspecto, a frequência está intimamente relacionada com a terceira dimensão da transação. 


\section{Incerteza}

A terceira dimensão das transações é a incerteza. Azevedo (1996) identifica duas formas de incerteza associadas à transação. A primeira, mais precisamente designada de risco, corresponde à probabilidade de ocorrência de um distúrbio de acordo com uma distribuição conhecida. A segunda, que corresponde de fato à incerteza, corresponde aos distúrbios que afetam a transação, mas sem uma distribuição de probabilidades conhecida. Um exemplo deste tipo de incerteza é a assimetria de informações entre os agentes envolvidos na transação, que os impossibilita de prever a forma de atuação um do outro.

Segundo Williamson (1991a), o aumento da incerteza (risco) na transação pode ser expresso pelo aumento da variância. Neste caso, a distribuição de probabilidades de ocorrência de um distúrbio sofre uma alteração que aumenta a incerteza associada à transação.

A incerteza associada a uma transação afeta a eficiência das formas organizacionais. Basicamente, quanto maior a incerteza maior a tendência à adoção de estruturas de governança hierárquicas. Na ausência de fidelidade e do conhecimento mútuo, há grandes incertezas associadas ao comportamento do agente com quem se estabelece a transação, de forma que a estrutura hierárquica passa a ser uma alternativa de redução de riscos. Dentre as diferentes formas organizacionais, a forma hibrida (intermediária ao mercado e à hierarquia) é a mais suscetivel à incerteza. 


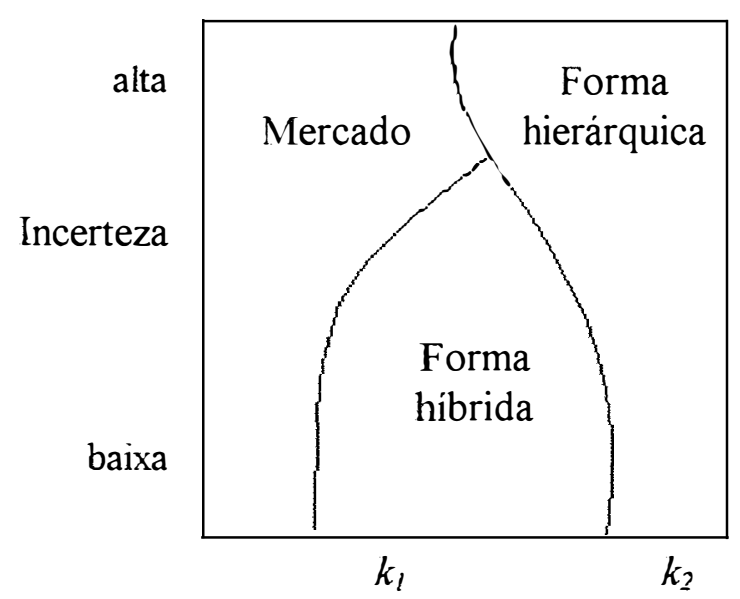

Especificidade de ativos

Figura 9 - Estrutura de Governança resultante da relação entre Incerteza e Especificidade. Fonte: Williamson (1991a, p.117)

Williamson (1991a) explica que adaptações contratuais na forma híbrida não podem ser realizadas unilateralmente (como ocorre no mercado e na forma hierárquica), mas requerem consenso. O consenso demanda tempo, e portanto a ocorrência frequente de distúrbios torna o processo de negociação infindável. Assim, na presença de alto grau de incerteza, a forma híbrida pode ser inviável.

\section{Modelo: A forma reduzida}

As dimensões da transação (especificidade do ativo, frequência e incerteza) associadas aos pressupostos comportamentais de racionalidade limitada e oportunismo, são os fatores componentes do modelo da ECT para a escolha da forma organizacional mais eficiente para governar uma transação. O modelo de Williamson (1991a), conhecido como "forma reduzida", tem como variável-chave a especificidade dos ativos. As demais dimensões da transação (incerteza e frequência) e os elementos do ambiente institucional (garantia de direitos de propriedade, disponibilidade de informações, códigos de ética etc. ) são incorporados ao modelo como parâmetros deslocadores das funções. 
Segundo Zylbersztajn (1995), as variáveis relevantes na teoria da ECT compõem três grupos que caracterizam, respectivamente: a transação, as relações contratuais e o ambiente institucional / organizacional, como indicado na tabela abaixo:

Tabela 14 - Variáveis Relevantes: Análise Estrutural Discreta Comparativa de SAGs

\begin{tabular}{|c|c|}
\hline Tipo & Variáveis \\
\hline Caracteristica da Transaçào & $\begin{array}{l}\text { Especificidade dos Ativos } \\
\text { Freqüência } \\
\text { Incerteza }\end{array}$ \\
\hline Aspectos Contratuais & $\begin{array}{l}\text { Flexibilidade ex-post } \\
\text { Desenho contratual } \\
\text { Incentivos } \\
\text { Arbitragem Pública / Privada } \\
\text { Confiança }\end{array}$ \\
\hline Ambiente Institucional & $\begin{array}{l}\text { Sistema Legal } \\
\text { Aspectos Culturais (Tradição e Costumes) } \\
\text { Organizações Políticas } \\
\text { Aspectos Internacionais }\end{array}$ \\
\hline Ambiente Organizacional & $\begin{array}{l}\text { Bureaus Públicos ou Privados } \\
\text { Associações, Organizaçōes Politicas } \\
\text { Informações / Tecnologia }\end{array}$ \\
\hline
\end{tabular}

Fonte: Zylbersztajn (1995)

Na forma reduzida, proposta por Williamson (1991a), as funções relacionam o custo de transação e o valor das características da transação. para cada forma organizacional, como representado abaixo:

$$
\begin{aligned}
& C T_{M}=f_{M}(k, \theta), \\
& C T_{Y}=f_{Y}(k, \theta), \\
& C T_{H}=f_{H}(k, \theta),
\end{aligned}
$$


Onde: $k=$ especificidade do ativo;

$\theta=$ vetor de parâmetros de deslocamento (incerteza, frequência e ambiente institucional)

$\mathrm{CT}_{\mathrm{M}}=$ Custo de transação da governança via mercado

$\mathrm{CT}_{\mathrm{X}}=$ Custo de transação da governança via contratos (terceirização)

$\mathrm{CT}_{\mathrm{H}}=$ Custo de transação da governança via hierarquia (integração vertical)

$f \mathrm{i}(\mathrm{i}=\mathrm{M}, \mathrm{X}, \mathrm{H})=$ funções específicas de custo para cada forma organizacional

Segundo Williamson (1991a), ao longo da ordenação das estruturas de governança (mercado, formas híbridas e hierarquia), perde-se em incentivo e ganha-se em controle. A perda da capacidade de incentivo refere-se ao incentivo promovido via sistema de preços, onde consumidores e produtores respondem às mudanças paramétricas dos preços de modo a maximizar sua utilidade e lucros, respectivamente. A medida em que as transações deixam de ocorrer no mercado e passam a ser governadas por contratos ou internamente à firma, os preços perdem sua capacidade de sinalização das decisões. Na ausência de sinalizadores de mercado, aumenta a necessidade de incentivos internos às firmas para que as partes envolvidas na transação ajam cooperativamente, visando maximizar a utilidade (ou lucro) de ambas.

Se por um lado, a estrutura hierárquica perde o incentivo via sistema de preços, por outro ganha em controle. De forma gradual, desde a organização via mercado até a completa verticalização, diminui a autonomia das partes envolvidas na transação, em troca da presença de salvaguardas específicas às transações, culminando, no caso da hierarquia, em controles administrativos ditados pelas relações de autoridade. A cada estrutura de controle criada corresponde um aumento dos custos burocráticos da empresa. O poder hierárquico, criado por estas estruturas de controle, é o mecanismo interno de adaptação das empresas às mudanças no ambiente institucional. 
O tradeoff entre capacidade de adaptação via sistemas de preços e custos de monitoramento e controle é que está por traz de uma importante questão tratada pela ECT: a escolha entre integração vertical, formas híbridas (contratos) ou mercado para governar a transação.

O tradeoff entre incentivo e controle fica claro no gráfico abaixo. Numa situação de ausência de especificidade de ativos, $\mathrm{k}=0$, o mercado é a forma de menor custo de transação, dado que não há estruturas formais de controle (baixos custos burocráticos) e o sistema de preços é suficiente para assegurar o ajuste do mercado e a plena realização das transações.

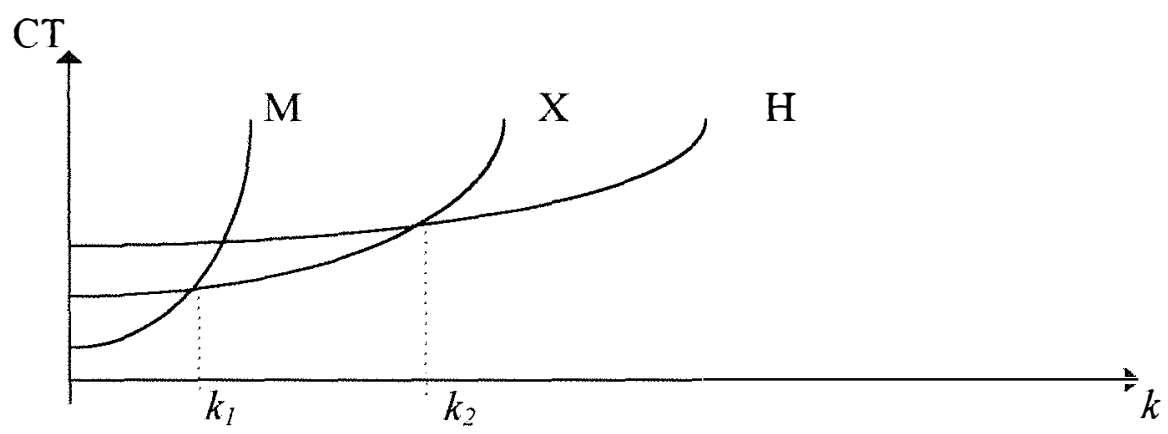

Figura 10 -Relação entre Custos de Transação (CT) e Especificidade de Ativos (k). Fonte: Williamson (1991a, p.108)

À medida que a especificidade do ativo aumenta, os preços passam a exercer pouco incentivo à realização da transação. As quase-rendas que emergem da dependência entre os agentes, faz com que as partes entrem num processo de barganha. Realizar a transação no mercado passa a ser mais caro do que via contratos de longo prazo, porque a burocracia dos contratos, em especial as salvaguardas estabelecidas, reduzem os custos de transação e a possibilidade de comportamento oportunístico por parte dos agentes. 
Em outras palavras, o aumento do controle da transação faz com que os custos de transação sejam menores, ou ainda, os custos de transação no mercado aumentam relativamente mais que nas demais formas à medida que aumenta a especificidade de ativos. Assim, como coloca Azevedo (1996), as derivadas das funções em relação à especificidade de ativo são positivas e decrescentes na seguinte ordem:

$$
M^{\prime}>X^{\prime}>H^{\prime}>0
$$

No caso extremo, onde a transação tem como característica uma especificidade muito elevada, o controle via hierarquia é aquele que garante o menor custo de transação, como indicado na Figura 10.

Esta é a essência da teoria, proposta na ECT, para a determinação da estrutura de governança mais adequada para cada transação. Baseando-se nesta estrutura, inúmeros trabalhos empíricos foram desenvolvidos. Alguns deles serão analisados a seguir, com o objetivo principal de identificar as potencialidades e limitações da ECT.

\subsection{Avaliação da ECT: Aplicações e Limitações}

A Economia dos Custos de Transação (ECT), associada à visão sistêmica do agribusiness, tem importantes contribuições às empresas com demanda por redução de custos e otimização das tomadas de decisão, através de modelos de análise da escolha de estruturas de governança que minimizam os custos de transação. Nesta seção do trabalho, pretende-se buscar evidências das contribuições e limitações da ECT em trabalhos empíricos. Ao longo da apresentação de alguns trabalhos quantitativos, serão ressaltadas as variáveis utilizadas para mensuração dos atributos da transação. Não se tem, em absoluto, a pretensão de percorrer todo o material produzido em ECT, mas apenas salientar alguns pontos relevantes para discussão. 
Num amplo trabalho de compilação e análise, Mahoney, Crank e Lajili (1994) identificaram os principais resultados de 16 pesquisas empiricas desenvoividas em ECT, abordando a questão da escolha da forma organizacional. As pesquisas abordam diferentes indústrias, incluindo a de componentes eletrônicos, petroquímica, de geração elétrica a partir do carvão, naval, automobilística, entre outras. Como proposto pela ECT, os autores de cada um destes 16 trabalhos buscam formas de quantificar os atributos das transações (principalmente especificidade do ativo e incerteza) para explicar as formas organizacionais observadas empiricamente. Na maior parte dos trabalhos foi constatada correlação estatisticamente significativa entre os atributos das transações e as formas organizacionais esperadas.

Nos trabalhos estudados por Mahoney, Crank e Lajili (1994), podem ser identificados diferentes tipos de especificidade de ativos através das variáveis utilizadas para sua quantificação: ativo dedicado (estimado pelo investimentos em $\mathrm{P} \& \mathrm{D}$ e pelo custo fixo total da planta industrial), ativo humano (estimado pelo grau de capacitação da mão de obra específica a determinada empresa ou produto), especificidade de ativo fisico (medida pelos usos alternativos de componentes industriais).

Ainda nos trabalhos estudados por Mahoney, Crank e Lajili (1994), as variáveis utilizadas para medir incerteza atendem, em sua maior parte, às definições de incerteza expostas na seção anterior. A maior parte destes trabalhos concentra as medidas de incerteza na variação do volume de oferta (ou de demanda) do ativo transacionado, o que corresponde a uma forma de medir a variação na ocorrência da transação (e portanto o risco desta não ocorrer).

Outra estimativa da incerteza foi feita através do número de anos em que uma tecnologia torna-se obsoleta. Este número, no entanto, não parece atender às definições de incerteza da transação. Isto porque, o risco da transação diz respeito ao risco de irregularidade no 
fornecimento do produto (gerado com o uso da tecnologia) que pode ser muito pequeno desde que haja um grande número de fornecedores. Assim, como a facilidade de obsolescència de uma tecnologia não necessariamente reduz o número de empresas atuantes em um mercado, a obsolescència tecnológica não deve ser usada como estimativa de incerteza. O número de empresas atuante no fornecimento do produto parece ser uma variajvel explicativa mais adequada para o grau de incerteza da transação.

Um importante resultado da análise desenvolvida por Mahoney, Crank e Lajili (1994) é a de que há uma equivalència entre a coordenação vertical via contratos e via integração vertical se forem desconsiderados os custos de transação. Assim, a grande contribuição da ECT é exatamente a de captar o diferencial entre estas formas, tornando possivel tanto a previsão como a prescrição das formas organizacionais que devem emergir dadas as caracteristicas da transação analisada.

Globerman e Schwindt (1986) estudaram a estrutura organizacional da indústria de produtos florestais canadense sob a ótica da economia dos custos de transação, evidenciando que considerações transacionais, particularmente especificidade de ativos, têm grande validade na determinação empirica das estruturas de governança.

Nos EUA, Ohanian (1994) testou um modelo explicativo da integração vertical de empresas produtoras de celulose com as de papel, em operação durante 1900 e 1940, baseando-se na teoria da ECT. A variável dependente utilizada foi o grau de integração vertical das empresas, enquanto as variáveis explicativas buscaram caracterizar custo de transação, frequència e especificidade do ativo. A proxy utilizada para os custos de transação foi a concentração dos mercados de celulose e de papel em diferentes regiões (o pequeno número de ofertantes ou demandantes da celulose favorece o comportamento oportunistico dos agentes, elevando os custos de transação e favorecendo a integração vertical). A frequência da transação foi estimada pelo tamanho da planta industrial de papel (plantas maiores necessitam com mais frequència da celulose, possibilitando a 
integração vertical sem perdas de escala). A especificidade do ativo celulose foi caracterizada pelo tipo de papel a ser produzido (a produção de tipos especiais de papel exige uma composição especifica de celulose e, neste caso, há uma tendência à integração vertical). Os resultados da regressão corroboraram as hipóteses formuladas e a validade do modelo.

No Brasil, Neves (1995) utilizou o ferramental teorico proposto pela ECT para estudar a viabilidade de um contrato de arrendamento da capacidade ociosa da indústria processadora no sistema agroindustrial citrícola para produtores de laranja. Neste estudo, a análise da decisão entre a verticalização ou não foi conduzida sob o ângulo do produtor rural e não da agroindústria. Numa análise essencialmente qualitativa, o autor descreve o SAG e busca caracterizar os atributos da transação para avaliar a viabilidade do contrato em questão.

Todos os trabalhos citados acima, aplicaram os conceitos de ECT na análise dos sistemas agroindustriais, procurando descrever as variáveis relevantes em cada um dos casos para a decisão entre "comprar" ou "fazer". Apesar dos contínuos avanços observados nos trabalhos empíricos desta linha de pesquisa, a principal limitação da ECT ainda refere-se à análise quantitativa. Os trabalhos quantitativos têm evoluído no sentido de buscar evidências numéricas para corroborar hipóteses, mas não são estimadas as funções que relacionam, para cada estrutura de governança, custos e atributos das transações.

Sem dúvida, a quantificação dos atributos e dos custos de transação é bastante problemática, dado o grau de subjetividade de alguns atributos e da dificuldade de mensuração dos custos de transação em sua totalidade. O problema da mensuração dos custos e atributos da transação é contornável nos trabalhos que objetivem estabelecer uma correlação entre as formas organizacionais observadas empiricamente e as caracteristicas da transação. através do uso de variáveis proxies. No entanto, nos trabalhos em que se deseja fazer prescrições a respeito de formas não observadas 
empiricamente, de nada valem as séries temporais, e assim surgem os trabalhos de cunho qualitativo.

Particularmente neste trabalho, em que a questão central de discussão é uma mudança institucional que pode mudar a estrutura organizacional vigente para uma estrutura jamais observada empiricamente, não há como fazer uso de modelos econométricos tradicionais. A opção encontrada foi buscar uma forma de estimar as funções que relacionam custos e atributos da transação, ainda que os valores utilizados sejam estimativas, na tentativa de evidenciar o efeito da mudança institucional em questão.

Nas partes seguintes deste trabalho, será apresentada a forma como os conceitos de ECT foram aplicados na análise de um estudo de caso do sistema agroindustrial da celulose. 


\section{3. análise das TransaÇões no SaG da celulose - estudo de Caso}

Nesta etapa do trabalho, a análise da escolha da estrutura organizacional para a transação de abastecimento de madeira na fábrica de celulose será desenvolvida num estudo de caso empírico.

Inicialmente, a empresa estudada será apresentada e, em seguida, será feita uma descrição da evolução do ambiente institucional vigente, desde o surgimento das empresas brasileiras de celulose e papel até o momento atual. Na parte seguinte, será feita a adequação do modelo da ECT para a quantificação dos atributos e custos de transação e estimação das funções que relacionam estas variáveis para cada estrutura de governança. Finalmente, será testada a hipótese de como as mudanças institucionais devem afetar as relações contratuais estabelecidas no abastecimento da fábrica de celulose.

\subsection{A Empresa}

\section{O Grupo Suzano ${ }^{17}$}

As origens da Companhia Suzano de Papel e Celulose remontam a 1923, quando foi constituída a Leon Feffer \& Cia., cujo objetivo era revender papéis nacionais e importados. A fase industrial da empresa foi iniciada em 1939, com a instalação da primeira máquina de papel, no bairro do Ipiranga em São Paulo. Em 1946, já sob a denominação de Indústria de Papel Leon Feffer S.A.. três conjuntos industriais estavam em operação.

\footnotetext{
${ }^{17}$ Baseado no material de divulgação institucional fornecido pela empresa.
} 
Até então, toda a matéria-prima celulose era importada e constituida de fibras de essências florestais cultivadas principalmente nos EUA, Canadá e nos paises nórdicos. Porém, já naquela época, algumas espécies do gênero Eucalipłus destacavam-se pela sua excelente adaptação às condições edafo-climáticas brasileiras e pelo seu crescimento acelerado. Estas características chamaram a atenção do Sr. Leon Feffer, atual Diretor Presidente da Cia. Suzano de Papel e Celulose, aguçando sua curiosidade a respeito da possibilidade de utilização das fibras de um gênero tão promissor à silvicultura brasileira na produção de papel.

Assim, em 1956 iniciaram-se as pesquisas de desenvolvimento da fabricação de celulose de eucalipto no laboratório da Universidade da Flórida, em Gainsville, alugado pela Indústria de Papel Leon Feffer S.A.. Após centenas de ensaios de cozimento, lavagem e branqueamento os resultados foram promissores: a celulose de eucalipto era viável.

No mesmo ano, foi adquirida uma empresa, no municipio de Suzano, para a instalação da fábrica de celulose de eucalipto. Em 1957, ocorreu a operação pioneira de fabricação de 25 toneladas/dia de celulose de eucalipto, e a produção de papéis de imprimir e escrever com $100 \%$ destas fibras.

Os anos que se seguiram foram marcados por constantes processos de pesquisa e desenvolvimento, e de investimentos em expansões e diversificações. Em 1974, movida por projeções de expansão do uso de materiais plásticos no segmento de embalagem, tradicionalmente dominado pelo papel, a empresa iniciou sua participação na área petroquimica, especificamente nas empresas Politeno Indústria e Comércio S.A. e Polipropileno S.A.

Paralelamente, continuava a evolução da capacidade de produção de celulose do grupo empresarial que veio a se chamar Companhia Suzano de Papel e Celulose. Já em 1989, após o término de um projeto de otimização, a Companhia atingiu a capacidade de 
produção de 420 mil toneladas/ano de celulose, colocando suas instalações industriais dentro dos padrões tecnológicos mais avançados de eficiência de produção, de qualidade de produto e, principalmente, de controle ambiental.

O grande salto em capacidade de produção do Grupo Suzano veio em 1992, com a partida na operação da planta de celulose da Bahia Sul Celulose S.A. ${ }^{18}$, com capacidade para produzir 500 mil toneladas/ano.

Em 1994, continuaram as expansões na indústria petroquímica, aumentando sua participação na Politeno de 20 para $35 \%$ do capital votante, e de $17,94 \%$ para 30,39\% do capital total. Durante o mesmo período, foi adquirida a participação de $49,99 \%$ das unidades de operação da Riverwood International no Brasil, conhecida como Igaras Papéis e Embalagens S.A.. O investimento foi equivalente à US\$ 100 milhões.

Nos anos seguintes, e em especial durante o ano de 1996, o grupo deu mais uma passo no processo de diversificação entrando no setor de telecomunicações.

\footnotetext{
${ }^{18}$ A Bahia Sul Celulose S.A. foi constituída pela Companhia Suzano (acionista majoritária. com $55 \%$ no capital rotante) em associação à Companhia Vale do Rio Doce.
} 

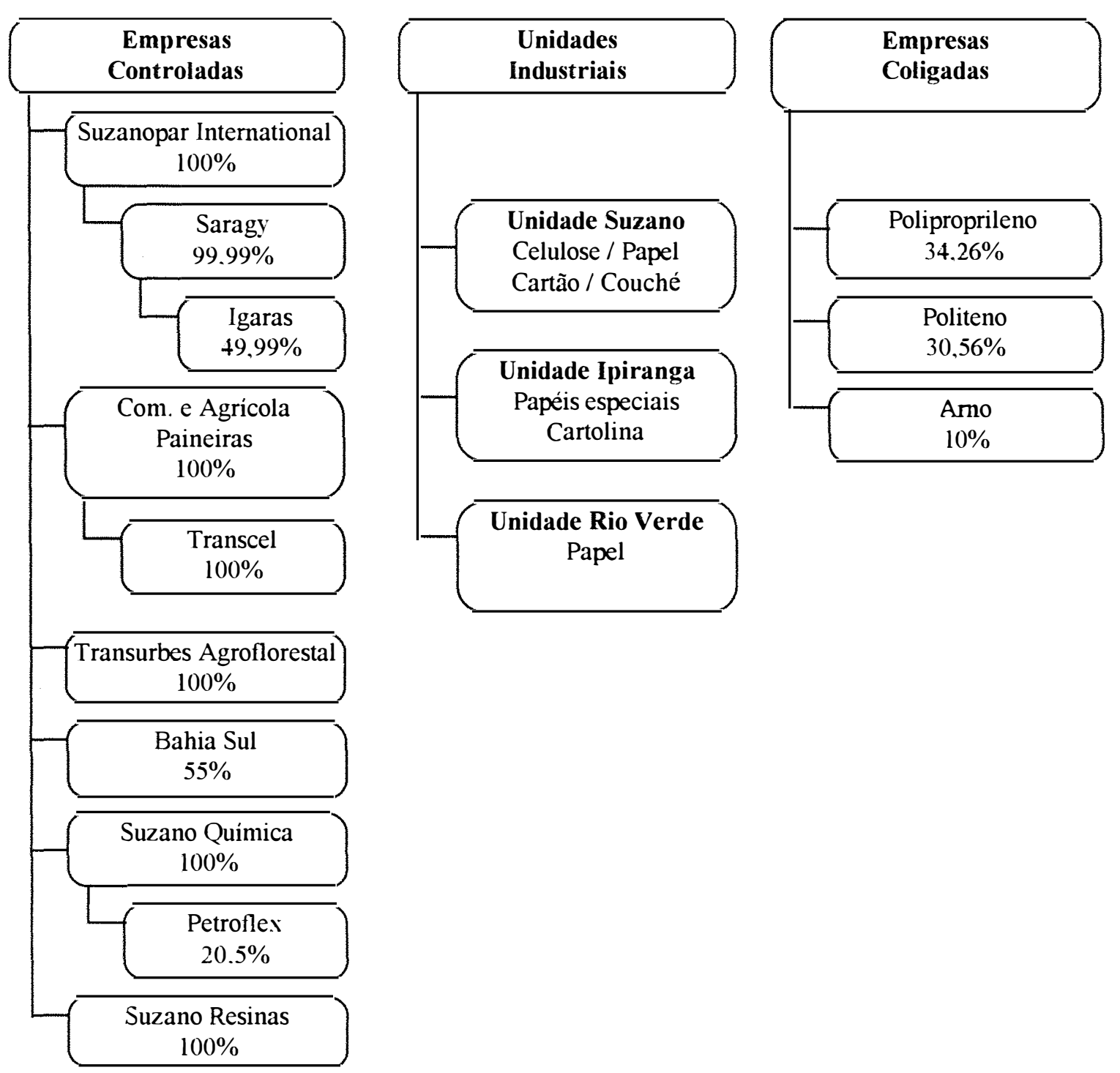

Figura 11 - Grupo Suzano 
A unidade industrial de Suzano é responsável pela produção de celulose para as demais unidades industriais, e está integrada a máquinas de papel, cartão e couché, caracterizadas na tabela abaixo. Esta unidade ocupa uma área total de $1.066 \mathrm{mil} \mathrm{m}^{2}$, com 195,7 mil $\mathrm{m}^{2}$ de área construída no município de Suzano - SP.

Tabela 15 - Unidades Industriais da Cia. Suzano.

\begin{tabular}{|c|c|c|}
\hline Unidade Industrial Suzano & Capacidade (ton /ano) & Produtos / Mercados \\
\hline \hline Fábrica de Celulose & 420.000 & $\begin{array}{c}\text { Celulose branqueada de fibra } \\
\text { de eucalipto (100\% E.C.F.) }\end{array}$ \\
\hline Unidade Industrial B5 MPII & 65.000 & $\begin{array}{c}\text { Papeis Couché (revistas, } \\
\text { livros, encartes e cartazes) }\end{array}$ \\
\hline Unidade Industrial B6 & 150.000 & $\begin{array}{c}\text { Cartões (embalagem) } \\
\text { livros, cadernos e xerografia) }\end{array}$ \\
\hline Unidade Industrial B7 & 105.000 & $\begin{array}{c}\text { Papel (formulário contínuo, } \\
\text { livros, cadernos e xerografia) }\end{array}$ \\
\hline Unidade Industrial B8 & 105.000 & Papel REPORT \\
\hline Conversão e Distribuição & & 150.000
\end{tabular}

Neste estudo de caso, a análise foco será a transação estabelecida entre a unidade industrial de Suzano e as empresas controladas Transurbes Agroflorestal e Comercial e Agricola Paineiras. Estas empresas controladas compõem a Divisão de Recursos Naturais (DRN), descrita a seguir. 


\section{A Divisão de Recursos Naturais - DRN}

A Divisão de Recursos Naturais - DRN é responsável pelo abastecimento de madeira das unidades industriais, tanto para a produção de celulose, como para a geração de energia. Para isso, a DRN é encarregada da administração e do manejo de todo o patrimônio florestal localizado nas regiões leste e oeste do estado de São Paulo, abrangendo a área de 50 mil hectares.

A região leste, acidentada, é composta pelas áreas localizadas nos municípios de Mogi das Cruzes, Paraibuna, Salesópolis, e São José dos Campos. A região Oeste, mais plana, inclui áreas nos municípios de Itatinga, Angatuba, São Miguel Arcanjo, Itapetininga, entre outros. A distribuição geográfica destas áreas determina um raio médio de transporte da madeira de $200 \mathrm{~km}$.

Os indices de produtividade, resultantes de constante pesquisa e melhoramento genético, alcançam atualmente cerca de $45 \mathrm{st} / \mathrm{ha}$.ano, de forma que as áreas próprias são responsáveis por $70 \%$ de auto-suficiência em madeira para as unidades industriais. A complementação do abastecimento de madeira é feita através de uma política de fomento a pequenos e médios produtores florestais, localizados na região leste do estado. $\mathrm{O}$ Programa de Fomento é feito através da distribuição gratuita de mudas de eucalipto e assistència técnica ao manejo das florestas, não havendo contratos formais de compra e venda de madeira. Em 1994, do total de mais de 8 milhões de mudas produzidas pela empresa, 2 milhões foram destinadas ao Programa de Fomento.

A divisão tem o compromisso de atingir os mais elevados padrões de produtividade sem prejuizo da conservação dos solos e da vida silvestre. A empresa foi uma das primeiras a utilizar o cultivo minimo florestal, que minimiza o impacto do preparo de solo, e a implantar um sofisticado programa de monitoramento ambiental das florestas. 
Internamente, a DRN está estruturada em diversos departamentos que se relacionam conforme a figura abaixo.

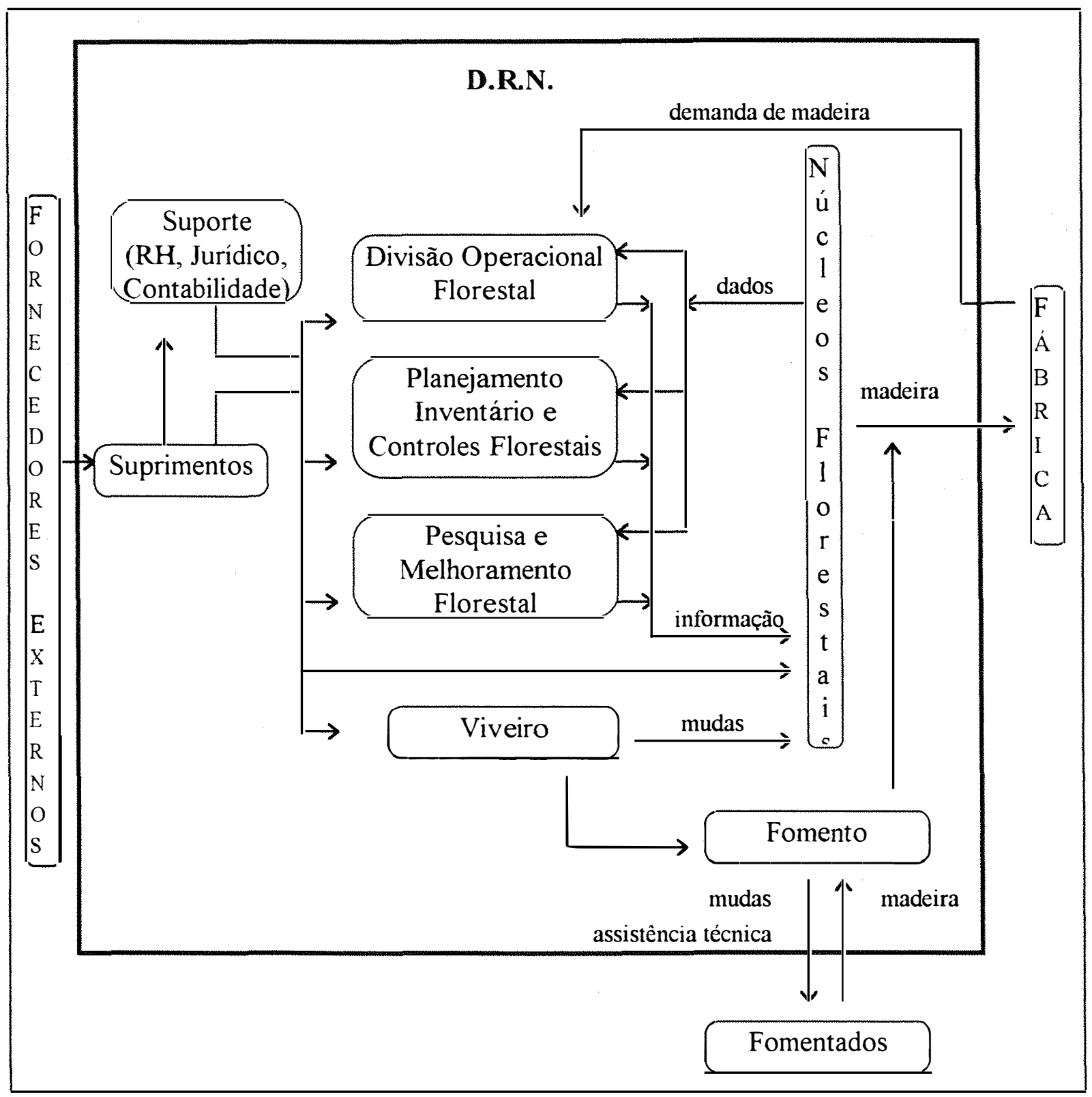

Figura 12 - Estrutura da D.R.N. 
Na Figura 12, observa-se que o principal cliente da DRN é a fábrica de celulose. Toda a organização da Divisão focaliza o abastecimento de madeira da planta industrial, seja através da produção própria, ou pela aquisição de madeira produzida por terceiros (fomentados).

As áreas de produção própria são chamadas de núcleos florestais (NFs). Os NFs compõem a área mais importante da DRN, à qual todas as demais dão apoio. Entre as áreas de apoio há aquelas responsáveis por abastecer os NFs com insumos para a produção florestal, como a área de suprimentos (adubo, inseticidas, peças etc.) e o viveiro (mudas).

As demais áreas indicadas na figura "abastecem" os NFs com informação a partir dos dados fornecidos pelos próprios núcleos. A Divisão Operacional Florestal gerencia a produção de madeira, centralizando a coordenação das atividades dos núcleos. A área do PIC (Planejamento, Inventário e Controles) trabalha especificamente com informações, apoiando a tomada de decisão. A pesquisa é a área de apoio que direciona em termos de material genético e de manejo florestal as atividades de produção dos Nfs. A área de fomento, como mencionado anteriormente, é responsável pela complementação do abastecimento da fábrica. Há ainda outras áreas de apoio que são responsáveis por questões essencialmente administrativas da empresa (RH, Setor Jurídico, Contabilidade etc.)

A compreensão da função de cada uma das áreas componentes da DRN e da relação estabelecida entre elas é fundamental. Isto porque parte do modelo quantitativo desenvolvido neste trabalho, mais exatamente a determinação de proxies para os custos de transação, baseiam-se fortemente na identificação das áreas burocráticas da empresa (que existem apenas em função da estrutura de governança hierárquica). Por isso a 
descrição das áreas da DRN será retomada mais adiante, no item da seção 3.3 que trata dos custos de transação.

\section{A escolha da Empresa para o Estudo de Caso}

A escolha da Cia Suzano para este estudo de caso deu-se por duas razões. A primeira delas é o histórico da empresa, apresentado brevemente no início desta seção. Trata-se de uma empresa sólida e estabelecida dentro de um grupo empresarial de sucesso, cujas estratégias merecem atenção, dado que estas levaram o grupo à disputada posição de maior produtor de papel no pais (Macedo e Matos, 1996).

A segunda razão que determinou a escolha da empresa está mais especificamente relacionada com os objetivos do trabalho e refere-se à evolução recente da composição do abastecimento desta empresa. Os dados da tabela abaixo demonstram que entre 1993 e 1996 houve uma importante alteração na estrutura de governança utilizada para o abastecimento de madeira. Durante este período, a empresa privilegiou a compra de madeira em detrimento da produção em áreas próprias, passando da quase total autosuficiência para pouco mais de dois terços de produção própria do seu insumo mais importante

Tabela 16 - Abastecimento com Madeira Própria e do Fomento (1993 a 1996)

\begin{tabular}{|c|c|c|}
\hline Ano & Madeira Própria (\%) & Madeira Fomento (\%) \\
\hline \hline 1993 & 89,01 & 10,99 \\
1994 & 82,63 & 17,37 \\
1995 & 76,97 & 23,03 \\
1996 & 72,48 & 27,52 \\
\hline
\end{tabular}


As razões para tal alteração na estrutura de abastecimento são o alvo deste trabalho. $\mathrm{O}$ enfoque da análise segue o modelo da Economia dos Custos de Transação, onde as dimensões da transação (especificidade do ativo, frequência e incerteza) são caracterizadas, bem como o ambiente institucional onde esta ocorre.

\subsection{Características da transação}

Nesta etapa do trabalho, pretende-se mostrar como se deu a escolha da estrutura de abastecimento das fábricas de celulose, na época em que estas estabeleceram-se no país. Será mostrado que a indústria tinha a opção de organizar sua base florestal numa estrutura hierárquica ou mista, e em um curto período via mercado também, mas optou pela estrutura hierárquica em função das características da transação de abastecimento. Pretende-se, ainda, mostrar que tais características explicam a manutenção da estrutura de governança, mesmo com o fim dos incentivos fiscais para o setor.

\section{Ambiente Institucional}

A consolidação da indústria de celulose nacional está intimamente relacionada ao Programa de Incentivos Fiscais ao Florestamento e Reflorestamento ${ }^{19}$, dados ao setor florestal brasileiro, durante as décadas de 60 a 80. Esse programa deve ser entendido dentro da estratégia geral de concessão de incentivos fiscais para o desenvolvimento regional (dos Estados do NE, NO e Espírito Santo), setorial (do reflorestamento, da pesca, do turismo e da EMATER) e social (para a alfabetização).

\footnotetext{
${ }^{19}$ Entende-se por Programa de Incentivos Fiscais ao Florestamento e Reflorestamento o conjunto de atos normativos de origem federal (leis. decretos-lei. decretos e portarias) que. elaborados no periodo de 1965 a 1988. instituiram e regulamentaram os incentivos fiscais a esta atividade (Bacha. 1993).
} 
Segundo Swioklo e Willadino (1996) a formulação da política de incentivos fiscais para o reflorestamento foi fundamentada por três pontos básicos:

- a constatação de que as reservas florestais brasileiras, localizadas nas regiões mais desenvolvidas, estavam em vias de extinguir-se;

- o descobrimento das condições excepcionais para o Brasil transformar-se em um dos maiores produtores e exportadores de matéria-prima florestal do mundo;

- a consciência de que, face às peculiaridades do investimento de longo prazo associado ao plantio de florestas, poucas seriam as chances de êxito para grandes empreendimentos caso não contassem com planejamento e apoio governamentais.

Esses incentivos surgiram, em parte, para viabilizar a reposição florestal dos consumidores de matéria-prima florestal e a auto-suficiência no abastecimento desta matéria-prima por parte de seus grandes consumidores (Bacha, 1993). A exigência da

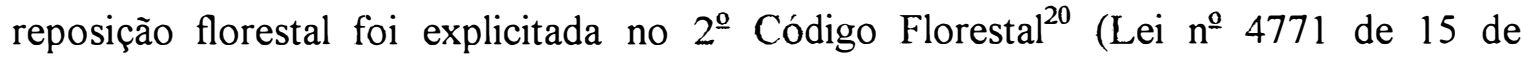
setembro de 1965), segundo os seguintes artigos:

Artigo 20 - "As empresas industriais que, por sua natureza, consumirem grandes quantidades de matéria-prima florestal serão obrigadas a manter, dentro de um raio em que a exploração e o transporte sejam julgados econômicos, um serviço organizado, que assegure o plantio de novas áreas, em terras próprias ou pertencentes a terceiros, cuja produção sob exploração racional, seja equivalente ao consumido para o seu abastecimento."

Artigo 21 - "As empresas siderírgicas, de transporte e outras, à base de carvão vegetal, lenha ou outra matéria-prima florestal, são obrigadas a manter florestas

\footnotetext{
${ }^{20}$ A primeira menção à necessidade de reposição florestal é encontrada no $1^{ }$Código Florestal (Decreto no 23.793 de 23 de janeiro de 1934. Artigo 26). Neste Artigo, as empresas siderúrgicas e de transporte ficam obrigadas a "manter em cultivo as florestas indispensáveis ao suprimento regular de lenha ou carvão de que necessitem. em áreas estabelecidas de acordo com a autoridade florestal". O Código Florestal de 1934 vigiu até setembro de 1965.
} 
próprias para exploração racional ou formar, diretamente ou por intermédio de empreendimentos dos quais participem, florestas destinadas ao seu suprimento.

Parágrafo Único - "A autoridade competente fixará para cada empresa o prazo que lhe é facultado para atender ao disposto neste artigo, dentro dos limites de 5 a 10 anos".

Observa-se, pelo conteúdo dos artigos acima, que em 1965 a indústria de base florestal tinha a opção de escolha entre duas estruturas de governança para o plantio de florestas. A primeira é a hierárquica, caso optasse por "manter ou formar florestas próprias". A segunda é a mista, através do estabelecimento de contratos com empresas reflorestadoras, caso optasse por formar florestas "por intermédio de empreendimentos dos quais participem". Não havia, naquele período, uma alternativa de mercado, ou seja, a legislação não concebia que as indústrias simplesmente adquirissem sua madeira de "produtores florestais", dado que desta forma a indústria estaria desvinculada da obrigação da reposição.

Em 1989, no entanto, as empresas passaram a ter a opção de mercado para abastecimento das fábricas. A Portaria Normativa do IBDF de nº 06-P (05/01/89) diminuiu a exigência efetiva de auto-abastecimento das grandes empresas consumidoras de matéria-prima florestal, estendendo até 1995 o prazo inicialmente estabelecido. Para as consumidoras de mais de 12.000 estéreos/ano (siderúrgicas, metalúrgicas, fábricas de celulose, aglomerados e similares, cerâmicas, cimenteiras, entre outras), desde que cumpridos $100 \%$ do seu cronograma de formação e manutenção de florestas (P.I.F.I.) ${ }^{21}$, poderiam adquirir parte da madeira no mercado. Esta parcela foi estabelecida em até $20 \%$

${ }^{21}$ O Plano Integrado Floresta-Indústria (P.I.F.I.) foi um documento. criado pela Portaria Normativa do IBDF $n^{\circ} 2+2$ de 17 de agosto de 1988. onde as indústrias. com consumo superior a $12.000 \mathrm{st} / \mathrm{ano}$ de madeira ou $4.000 \mathrm{~m}^{3}$ de carvão. deveriam apresentar um cronograma de formação e manutenção de florestas para seu abastecimento. No P.I.F.I. poderiam constar as seguintes fontes de matéria-prima:

- projetos técnicos de reflorestamento e/ou levantamento circunstanciado de área plantada:

- plano de manejo de rendimento sustentado das áreas sob exploração: 
do volume gerado pelos plantios efetuados com recursos próprios ou vinculados (com recursos dos incentivos). Desta forma, a indústria poderia comprar no mercado volume equivalente à $17 \%$ daquele necessário ao seu abastecimento.

Simultaneamente ao início do vigor da legislação de reposição florestal, surgiu no Brasil o já mencionado Programa de Incentivos Fiscais ao Florestamento e Reflorestamento, o qual acreditamos ter influência direta na escolha da estrutura de governança para $o$ abastecimento das fábricas de celulose.

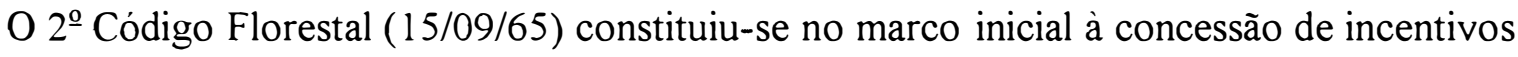
a empreendimentos florestais através do imposto de renda (Artigo $38, \S \S 1^{\mathrm{o}}$ e $2^{\mathrm{o}}$ ) ${ }^{22}$. A forma de utilização do incentivo, preconizada pelo Código de 65, teve efeito apenas para o exercício financeiro de 1966, ano base 65, pois em abril de 1966 foi editada a Lei $\mathrm{n}^{\mathbf{o}}$ 5106 que revogou o artigo 38 da Lei $4771 / 65$ e seus parágrafos $1^{\circ}$ e $2^{\circ}$.

O incentivo ao florestamento e reflorestamento, oferecido pela Lei $n^{0} 5106$ às pessoas fisicas, resumia-se da seguinte maneira: as importâncias comprovadamente aplicadas em florestamento e reflorestamento, no transcurso do ano-base, desde que realizadas de acordo com projeto aprovado pelo $\operatorname{IBDF}^{23}$ (Instituto Brasileiro de Desenvolvimento Florestal), poderiam ser deduzidas da renda bruta. no momento da declaração de rendimentos do exercício financeiro no ano-base da aplicação. Este procedimento perdurou (com alterações nos percentuais permitidos para abatimentos) até dezembro de

\footnotetext{
- execução ou participação em programas de fomento florestal aprovados pelo extinto Instituto Brasileiro de Desenvolvimento Florestal.

2 A redação deste artigo é:

"Artigo 38 - is florestas plantadas ou naturais são declaradas imunes a qualquer tributação e não podem determinar, para efeito tributário, aumento do valor das terras em que se encontram.

Parágrafo $l^{\circ}$ - lão se considerará renda tributável o valor de produtos florestais obtidos em florestas plantadas, por quem as houver formado.

Parágrafo $2^{\underline{0}}$ - As importâncias empregadas em florestamento e reflorestamento serão deduzidas integralmente do imposto de renda e das taxas especificas ligadas ao reflorestamento.

${ }^{23}$ Extinto orgão governamental encarregado de conduzir a politica florestal do pais. Suas funções são exercidas hoje pelo IBAMA - Instituto Brasileiro do Meio Ambiente e dos Recursos Naturais Renováveis.
} 
1980, quando foi promulgado o Decreto-lei $\mathrm{n}^{\mathrm{o}}$ 1841. Embora este não tenha explicitamente revogado a aplicação de recursos dos incentivos fiscais de pessoas físicas, nos moldes da Lei n⿳ 5 106/66, esta prática tornou-se impossível. Já as pessoas jurídicas, segundo a Lei $\mathrm{n}^{0} 5106 / 66$, poderiam descontar uma parcela de 50\% do imposto de renda devido. Este incentivo durou até 23 de dezembro de 1976, com o surgimento do Decreto-lei $n^{0} 1503$.

O mecanismo da Lei $n^{\text {o }}$ 5106/66 gerava um intervalo de tempo entre a realização da despesa e o recebimento do beneficio. Segundo Arienti (1983), citado por Bacha (1993), esse intervalo de tempo gerava très dificuldades: i) a empresa deveria prever o IR a pagar para saber o valor máximo ( $50 \%$ do IR devido) que receberia de incentivo; ii) havia a perda gerada pela inflação no período, ou seja, aplicava-se certo valor no ano-base e recebia-se o mesmo valor nominal no ano de exercício; e iii) ocorria o risco do projeto não ser aprovado pelo IBDF.

Pressōes surgiram para corrigir estes problemas, culminando no Decreto-lei. $\mathrm{n}^{\mathrm{o}} 1134 \mathrm{em}$ 16 de novembro de 1970 que, simultaneamente à Lei $\mathrm{n}^{0}$ 5106/66, disponibilizava incentivos fiscais para o reflorestamento. Desde então, as pessoas juridicas puderam descontar 50\% do valor do IR devido na declaração de rendimentos, para a aplicação em empreendimentos florestais cujos projetos tivessem sido aprovados pelo IBDF. O motivo apresentado pelo Congresso para a edição do novo Decreto-lei foi, entre outros, o acanhado resultado obtido pelo incentivo fiscal à silvicultura até então, mostrando a ineficiència do mecanismo anterior.

O Decreto-lei $n^{\text {o }} 1134 / 70$ autorizou duas formas de organização das empresas responsáveis pelos empreendimentos florestais: a Firma com Participação Societária Acionária e a Firma com Participação Societária Não Acionária em Projetos de Pluriparticipação (equiparada pelo Artigo 16 do Decreto nº 68.565 de 29/04/71 a uma Sociedade em Conta de Participação, SCP). Quando o IR fosse pago, a parcela de 
incentivos fiscais seria depositada no Banco do Brasil e, em seguida, transferida aos projetos (já aprovados) indicados pelo optante. Empresas, com projetos de reflorestamento aprovados, procuravam investidores para seu empreendimento, convencendo-os a aplicar seus recursos deduzidos do IR. As empresas de maior porte executavam, elas mesmas, seus projetos florestais, na qualidade de administradoras das sociedades em conta de participação.

Para as empresas organizadas sob a forma de Participação Societária Acionária, exigiamse recursos próprios "nunca inferiores a uma terça parte do montante dos recursos descontados do imposto de renda" (Artigo 5 $5^{\underline{0}}$ do Decreto-lei nº 1134). Em uma Sociedade em Conta de Partipação, o investidor aplicava apenas os incentivos fiscais e recebia Certificados de Participação em Reflorestamento - $\mathrm{CPR}^{24}$. A possibilidade de aplicar incentivos fiscais em projetos de reflorestamento sem a contrapartida de recursos próprios (caso das SCP) não existia para as outras opções de alocação de incentivos fiscais regionais e setoriais e conduziu, na opinião de Bacha (1993), a um aumento da alocação de incentivos fiscais para projetos de reflorestamento.

Esta foi a primeira grande fase do reflorestamento incentivado, e aqui residem as primeiras variáveis explicativas, de cunho institucional, para o modelo hierárquico adotado pela indústria de papel e celulose brasileira. Fica claro, observando o conteúdo da Lei $n^{\text {o }}$ 5106/66 e do Decreto-lei n⿳ $1134 / 70$, que os incentivos favoreceram em muito às pessoas jurídicas. A Lei $\mathrm{n}^{\mathbf{0}}$ 5106/66, que contemplava as pessoas físicas, embora permitisse o desconto dos recursos investidos em reflorestamentos no IR, exigia que os

24 O procedimento de liberação dos recursos para essas sociedades era bastante simples: uma vez aprovado o projeto. era assinado o contrato em conta de participação entre a empresa reflorestadora (sócia gerente) e alguns investidores (sócios participantes). O "capital" da sociedade recém formada era sempre o valor integral do projeto. calculado segundo os custos estabelecidos pelo IBDF. A fim de completar esse "capital". as empresas administradoras angariavam novos sócios (investidores) e. através de procuração. os incluíam no corpo da sociedade. através de "Termo de Adesão". Muitas vezes. estas sociedades eram formadas por quase uma centena de sócios. Mediante o instrumento procuratório. a administradora recebia do IBDF. mais precisamente do Diretor do Depto. de Reflorestamento. um cheque 
produtores $^{25}$ tivessem de antemão tal recurso, e mais, que estivessem dispostos a utilizálos num investimento de longo prazo e alto risco ${ }^{26}$. Obviamente, o incentivo teve muito pouco efeito sobre os produtores. Por outro lado, o Decreto-lei $n^{0} 1134 / 70$, destinado às pessoas jurídicas, permitiu estabelecer a base florestal necessária para o estabelecimento da indústria nacional de celulose e papel (apesar do uso bastante questionável de boa parte dos recursos disponibilizados por tal decreto).

Em tese, os incentivos fiscais criariam três estruturas organizacionais alternativas para a indústria de celulose, como representado na figura 3. A primeira alternativa seria o $\underline{\text { mercado florestal, }}$ criado a partir dos incentivos para pessoas fisicas (produtores rurais) ou para pessoas jurídicas (empresas reflorestadoras). A segunda alternativa de abastecimento seria a base florestal própria, onde as empresas produtoras de celulose estariam integradas verticalmente (estrutura hierárquica), e a terceira alternativa seriam

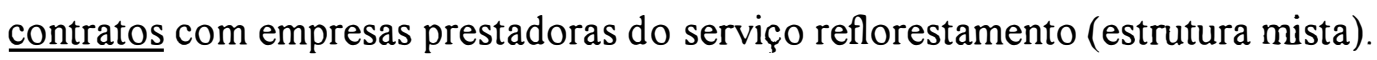

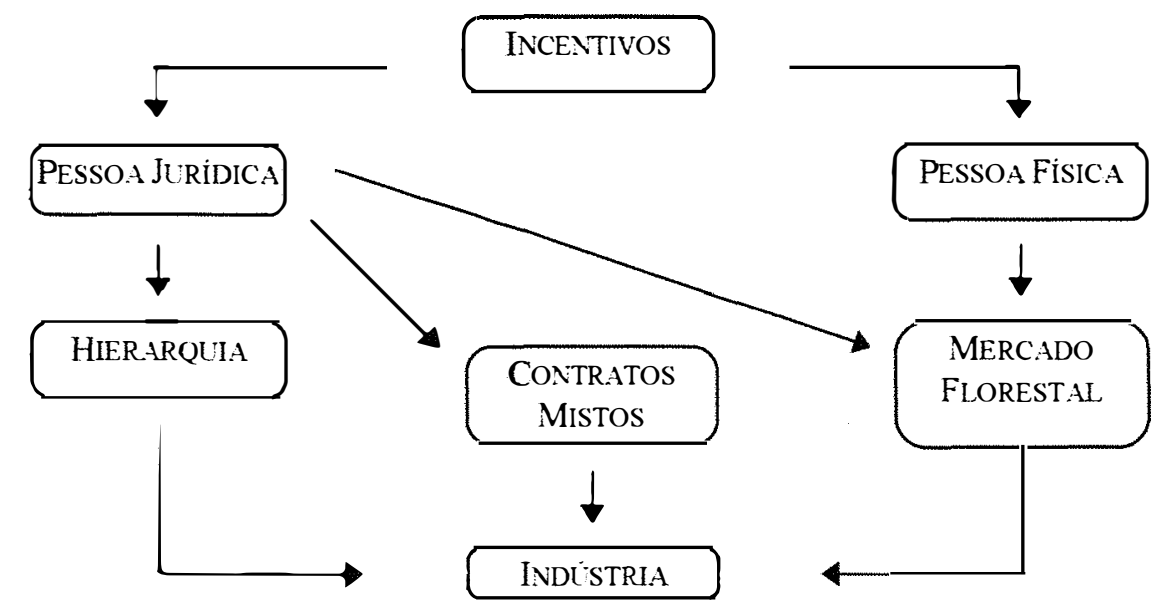

Figura 13 - Estruturas de Governança Alternativas para as Empresas de P\&C.

nominal. em seu favor. no valor da aplicação realizada pelo novo sócio. que poderia ser. de imediato. descontado no Banco do Brasil (Swioklo e Willadino. 1996).

$\because 5$ O termo "produtor" será utilizado para designar as pessoas fisicas ligadas à produção florestal. enquanto as pessoas jurídicas serão identificadas por empresas reflorestadoras.

${ }_{26} \mathrm{O}$ alto risco está associado à ausência de grandes indústrias consumidoras da madeira naquela época. de forma que o plantio de florestas consistia num investimento de especificidade muito elevada para um produtor realizá-lo. 
No entanto, como apresentado anteriormente, a exigència da reposição florestal não permitia que o abastecimento dos grandes consumidores de madeira fosse realizado através da aquisição no mercado. Assim, mesmo que os incentivos tivessem viabilizado a formação de propriedades produtoras de madeira, o mercado não representava uma alternativa factivel para as empresas.

Uma vez descartada a estrutura de governança via mercado, a indústria ainda tinha duas outras alternativas para seu abastecimento: contratação de empresas reflorestadoras ou integração vertical. Ambas alternativas eram viáveis, uma vez que os incentivos poderiam ser aplicados pela indústria consumidora num empreendimento gerenciado pela empresa reflorestadora, sem integrar-se verticalmente. Neste caso, as características do ativo "floresta" (apresentadas nos próximos itens deste trabalho) passam a ser os fatores determinantes dos custos de transação associados às diferentes estruturas de governança.

Gradativamente, os incentivos fiscais foram reduzidos. Inicialmente, em função das distorções no sistema (práticas irregulares de intermediação, com o oferecimento ilegal de comissões de corretagem), em seguida, pela consolidação do setor florestal identificada pelo governo e, principalmente, pela séria crise fiscal enfrentada pelo Estado. Em 1986, um pacote de normas emitidas pelo governo federal minimizou os recursos disponiveis ao reflorestamento, e em dezembro de 1988, com a aprovação da Lei $\mathrm{n}^{0}$ 7414, foi encerrada a política de incentivos fiscais para a implantação de empreendimentos florestais no pais.

Se por um lado os incentivos fiscais foram encerrados, por outro, a exigència da reposição florestal foi mantida. Atualmente, esta exigència é regulamentada pelo Decreto nº 1282, de 19 de outubro de 1994, e pela Instrução Normativa n⿳0 1, de 05 de setembro de 1996. Segundo estes instrumentos legais, as empresas produtoras de celulose continuam com as mesmas alternativas de estrutura de governança hierárquica ou mista, 
devendo apresentar um demonstrativo anual das fontes de suprimento de matéria-prima florestal voltada ao abastecimento da unidade consumidora (agora chamado P.I.F. - Plano Integrado Florestal). As alternativas para a reposição continuam sendo florestas plantadas (próprias ou em participação com terceiros) e florestamento ou reflorestamento em programas de fomento florestal. Não é mencionada a possibilidade de aquisição de madeira no mercado. 

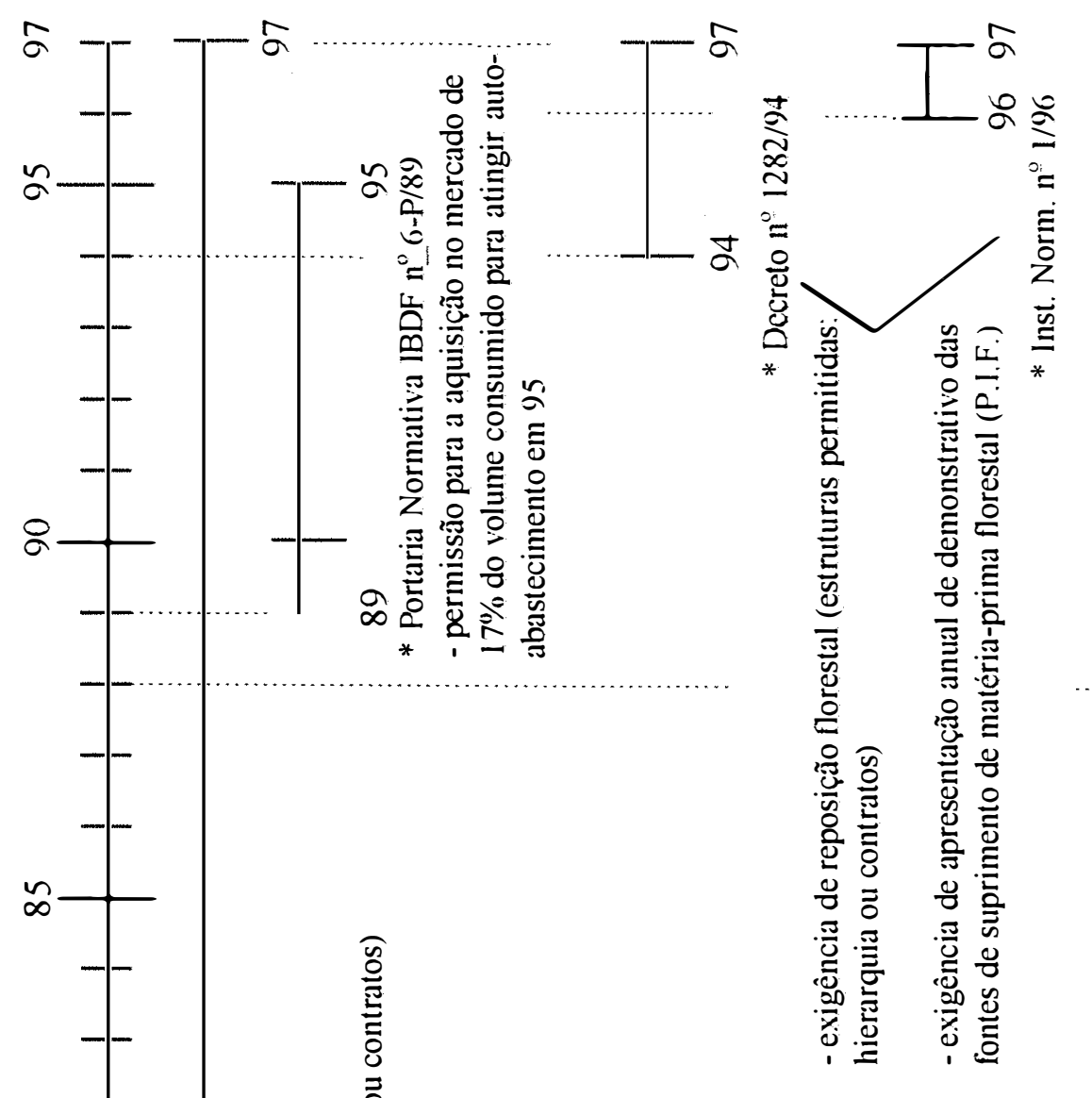
O término dos incentivos alterou o ambiente institucional, surgindo a necessidade de redefinição da melhor estrutura de governança para a transação de abastecimento das fábricas de celulose (alternativas T4 ou T4'da Figura 1). Na ausência dos incentivos, os custos de produção aumentaram, criando a possibilidade de viabilizar a terceirização da base florestal (dentro dos limites impostos pela legislação de reposição florestal) ${ }^{27}$.

Empiricamente, observa-se que a elevação nos custos de produção causou grande impacto na estrutura de produção florestal. De fato, Bacha (1993) e Larson, Rodriguez e Azevedo (1994) argumentam que o fim dos incentivos fez com que as empresas florestais procurassem alternativas para viabilizar sua base florestal própria, e apresentam o fomento florestal como uma das formas de complementação do abastecimento adotada pelas empresas consumidoras de madeira. Trata-se do "...incentivo ao reflorestamento em pequenos e médios estabelecimentos rurais, através de acordos com a predominância de garantia da compra da madeira reflorestada e parceria no plantio..." (doação de mudas, insumos e assistência técnica) (Bacha, 1993).

Além dos custos de produção, os custos de transação são fatores essenciais na determinação da estrutura de governança mais eficiente para as empresas. A avaliação dos custos de transação depende, no entanto, da caracterização dos atributos da transação, apresentada nas etapas seguintes deste trabalho.

\footnotetext{
Z"É importante ressaltar que apesar dos incentivos fiscais terem sido extintos em 1988. o processo de desvinculação das florestas junto ao IBAMA. permitindo legalmente a total terceirizaçào da base florestal. só será concluido quando o último projeto incentivado completar 21 anos. portanto em 2009. Até esta data. as empresas que desejarem podem terceirizar gradualmente a base florestal. naquelas áreas em que a prestação de contas relativa aos recursos do incentivo estiver concluída.
} 
Quantificando a ECT: estimativas para os atributos e custos de transação

Nesta etapa do trabalho, serão apresentados os critérios utilizados para a quantificação dos conceitos da Economia dos Custos de Transação (ECT), na análise da transação de abastecimento de madeira na fábricas de celulose.

A proposta da forma reduzida, apresentada por Riordan e Williamson (1985), era a de formalizar a teoria da ECT permitindo o teste empírico das proposições levantadas pela teoria. No entanto, como discutido no capítulo anterior, o teste quantitativo de hipóteses na ECT ainda sofre uma série de limitações

A rigor, e em particular neste trabalho, o que se espera da teoria é a possibilidade de estimação das funções que relacionam os custos e os atributos da transação. Isto significa que uma análise quantitativa ideal para a transação seria feita a partir da estimação de valores para os custos de transação, bem como para a especificidade dos ativos. Os demais atributos da transação (frequência e incerteza) serão caracterizados, porém não serão incorporados ao modelo quantitativo, dado que não sofreram alteração significativa durante o periodo de análise.

A seguir, serão descritas as estimativas dos custos e atributos da transação estudada.

\section{Frequência da Transação}

Como apresentado no capítulo 2, a importància da frequência da transação reside na sua relação com a escala de produção (quanto maior a frequência, maior a possibilidade de internalizar a transação com ganhos de escala) e com a possibilidade de conhecer melhor o agente com quem se estabelece a transação. 
A caracterização da transação de abastecimento da fábrica de celulose com madeira tem na frequència uma importante peculiaridade. Do ponto de vista da fábrica, a frequência da transação de compra de madeira é indiscutivelmente elevada. Isto ocorre basicamente em função do processo industrial de polpeamento ser continuo, de forma que a demanda por madeira ocorre 24 horas por dia.

Se, por um lado, a elevada frequência da transação permite e estimula a verticalização das empresas em função da escala de produção, por outro, ela também estimula que fornecedores ajam de forma idònea. Isso porque, a garantia da recorrência da transação depende da reputação de tais fornecedores.

Assim, a frequência elevada da transação de abastecimento, associada à especificidade locacional do ativo madeira, funciona como um incentivo para o fornecedor entregar a madeira à empresa e estabelecer com esta um vínculo estreito de negociação (apesar da ausência de um contrato formal de compra e venda).

A relação entre alta frequência da transação e reputação dos agentes pode explicar, em parte, o estabelecimento de uma estrutura de governança composta parte pela hierarquia e parte por contratos informais. A certeza da boa reputação dos fornecedores permite à empresa obter a madeira sem custos de controle, no entanto, a estrutura de governança formada em parte pela hierarquia e em parte por contratos verbais é possivel apenas numa proporção tal que a maior parte seja hierárquica.

A medida em que há um aumento da proporção da madeira adquirida de produtores autònomos, estes passam a ganhar um poder de barganha sobre a empresa, ou seja, surge uma quase-renda na transação e a necessidade da empresa salvaguardar-se contra o rompimento do contrato de abastecimento. Assim, caso a proporção do abastecimento proveniente de contratos com fornecedores autònomos seja elevada, tais contratos não 
mais poderão ser verbais e, portanto, o custo de administração destes contratos pode favorecer a verticalização.

O que se constata na análise da frequência da transação de abastecimento de madeira é a tendência à verticalização, com possibilidade de manutenção de uma parte dos contratos informais.

A incerteza no abastecimento de madeira será analisada a seguir, de forma a complementar a caracterização da transação.

\section{Incerteza}

Assim como a recorrência da transação, riscos elevados favorecem a forma organizacional integrada. Estes últimos estão diretamente relacionados à especificidade do ativo, uma vez que o risco de falta de matéria-prima para a fábrica (ou de demanda por madeira, pela ótica do produtor florestal) ocorre em função da ausência de mercados alternativos de compra e venda de madeira. Assim, parte da incerteza associada ao abastecimento da fábrica de celulose pode ser captada pela variação da demanda por madeira na fábrica.

O gráfico abaixo apresenta a flutuação do abastecimento mensal da Cia. Suzano ao longo de quatro anos. A partir destes dados, foram calculados alguns indicadores do grau de dispersão do volume demandado de madeira pela fábrica de celulose. 


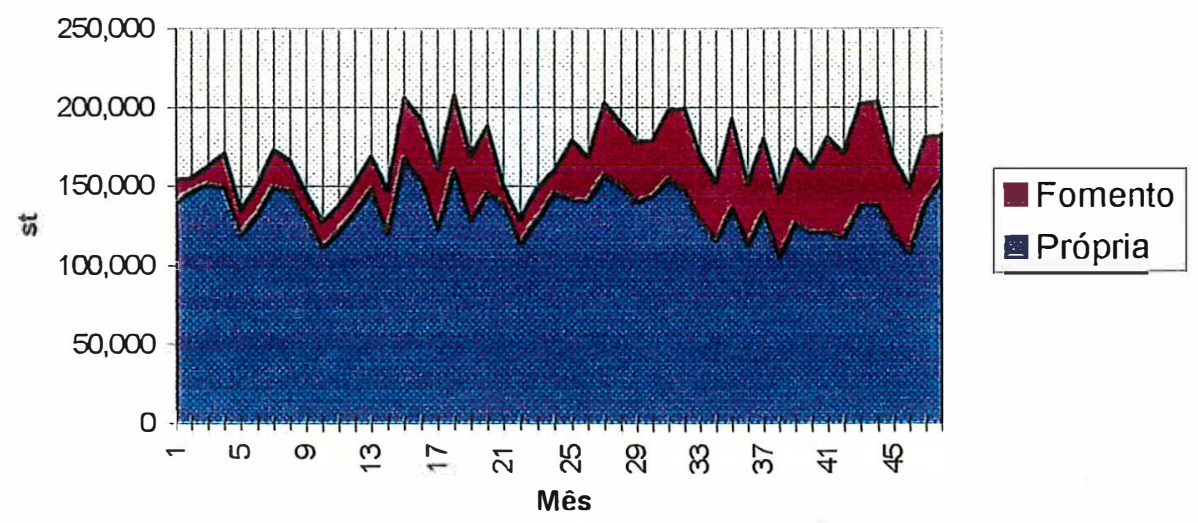

Figura 15 - Composição do Abastecimento Mensal da Fábrica de Celulose (1993 a 1996).

Ao longo dos quatro anos, compreendidos entre janeiro de 1993 e dezembro de 1996, a fábrica recebeu, em média, 169.162 estéreos $^{28}$ de madeira por mês. Neste período, é possível observar a sazonalidade anual do abastecimento. Este sofre uma aceleração a partir do mês de outubro até o final de cada ano, quando o ritmo de produção diminui. Ao longo dos meses, a entrega de madeira volta a crescer, até que no meio do ano aparecem os picos de abastecimento. Deste momento, até o mês de outubro, a demanda por madeira volta a se desacelerar fechando o ciclo. Apesar deste ciclo, é possível constatar que os últimos dois anos do período foram particularmente interessantes, dado que entre o final de 95 e o início de 96 o abastecimento praticamente não sofreu redução.

Num período de grande oscilação do abastecimento, entre outubro de 93 e junho de 94, o volume de madeira entregue na fábrica atingiu os valores mínimo e máximo de 127.378 e 207.328 st, respectivamente. Estes valores representam um aumento de $62,77 \%$ no volume em apenas 8 meses.

${ }^{28} 1$ estéreo $=1 \mathrm{~m}^{3}$ empilhado 
Os dados analisados mostraram uma variação equivalente a cerca de 21.000 st em torno da média de abastecimento no período. Isto equivale a uma flutuação de $12,35 \%$ do volume de madeira entregue, em média, a cada mês.

Tabela 17 - Variação no Abastecimento de Madeira Cia Suzano.

\begin{tabular}{|l|c|c|}
\hline \multicolumn{1}{|c|}{ Indicador } & Unidade & Valor \\
\hline \hline Valor Mínimo & st & 127.378 \\
Valor Máximo & st & 207.328 \\
Variação entre mínimo e máximo & $\%$ & 62,77 \\
Variância & st & 436.506 .638 \\
Desvio Padrão DP & st & $20.892,741$ \\
Média & st & 169.162 \\
DP / média & $\%$ & 12,35 \\
\hline
\end{tabular}

A elevada flutuação do abastecimento pode ser considerada como um indicador da ocorrência de alto risco na transação. Neste caso, a estrutura de governança mais indicada tende a ser a hierárquica. Apesar de se verificar uma tendência à integração vertical, as evidências levantadas a favor da hierarquia não parecem suficientemente fortes para garantir a superioridade desta estrutura.

Para complementar a análise da transação e tornar clara a prescrição de uma estrutura de governança, serão apresentados os critérios utilizados para estimação da especificidade do ativo e dos custos de transação, bem como as funções que relacionam tais custos.

\section{Especificidade dos Ativos}

Inicialmente, foram identificados os principais tipos de especificidade relacionados ao ativo madeira na transação de abastecimento da fábrica de celulose. Para Azevedo (1996) essa distinção entre os vários tipos de especificidade presta-se, sobretudo, à análise 
empírica, iluminando as especificidades mais comuns e a forma em que elas se materializam no mundo real.

De acordo com a classificação proposta por Williamson (1991a), apresentada no capítulo 2, há três importantes tipos de especificidades do ativo madeira na transação de abastecimento da fábrica de celulose: física, locacional e de ativo dedicado. Para evidenciar a ocorrência destas especificidades da madeira na transação de abastecimento das fábricas de celulose, é necessário mostrar que o valor da madeira em transações alternativas ao abastecimento da fábrica de celulose é menor.

A especificidade de ativos dedicados pode ser representada como uma função da quantidade transacionada ou, alternativamente, da proporção daquilo que é transacionado relativamente ao total do mercado (Azevedo, 1996). Assim, há especificidade de ativo dedicado quando o reemprego do ativo implica numa alteração significativa do preço dos produtos ou serviços gerados por esse ativo.

O crescimento da produção de celulose, tanto para exportação como para consumo das fábricas de papel, direcionou os plantios de florestas para o abastecimento das plantas industriais. É o que ilustra o gráfico abaixo. No período compreendido entre 1991 e 1993, cerca de $45 \%$ do volume de madeira produzido nas florestas plantadas era designado para a produção de papel e celulose. Configura-se assim uma relação de dependência mútua entre os agentes envolvidos na transação fundada. sobretudo, em ativos específicos dedicados. 


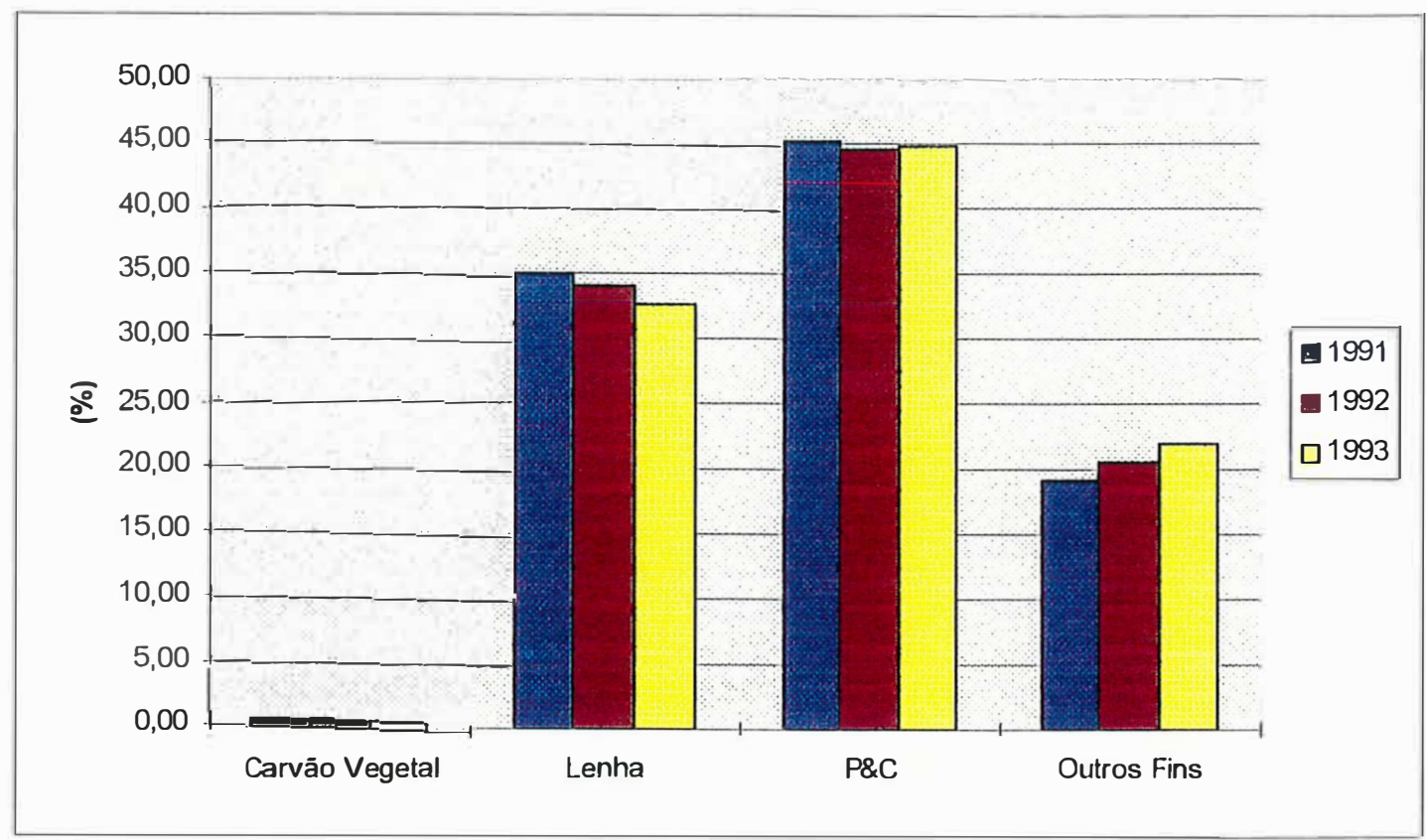

Figura 16 - Utilização da Madeira de Florestas Plantadas no Estado de S.P. (\%). Fonte: IBGE (1995).

Particularmente no caso da empresa estudada, o mercado da madeira de eucalipto num raio de aproximadamente $100 \mathrm{~km}$ é restrito a três usos: madeira para a produção de fibras e geração de energia nas duas fábricas de celulose da região, madeira para pontaletes utilizados pela construção civil e madeira para a produção de carvão. Observando-se os números apresentados na tabela abaixo, fica claro o direcionamento da madeira para o consumo das fábricas de celulose. Do volume total de eucalipto produzido na região, $87 \%$ foi consumido por estas empresas.

Tabela 18 - Consumo de Madeira das Empresas num raio de $100 \mathrm{~km}$ da Cia Suzano

\begin{tabular}{|c|c|c|}
\hline Empresa & Produto Final & Consumo Anual (\%) \\
\hline \hline Fábricas de Celulose & Celulose / Papel & 87 \\
Construção Civil & Pontalete & 9 \\
Carvoaria & Carvão & 4 \\
\hline
\end{tabular}

Fontc: Cia. Suzano 
A especificidade locacional da madeira na transação de abastecimento das fábricas de celulose diz respeito à distância entre as áreas de plantio e a fábrica. A localização próxima de firmas de uma mesma cadeia produtiva economiza os custos de transporte e armazenagem, significando retornos específicos a essas unidades produtivas (Azevedo, 1996).

A existência de um raio economicamente viável para o abastecimento das fábricas é um fato. Fora deste raio, a madeira perde completamente o valor para a empresa produtora de celulose, e dentro dele ganha em valor à medida em que se aproxima da fábrica. $\mathrm{O}$ aumento de valor da madeira localizada próxima à fábrica é, na verdade, a redução do custo com transporte, como indica o gráfico abaixo. ¿̇ medida em que a distância percorrida para abastecer a fábrica diminui, o valor do transporte, expresso por unidade de volume transportada, também é menor.

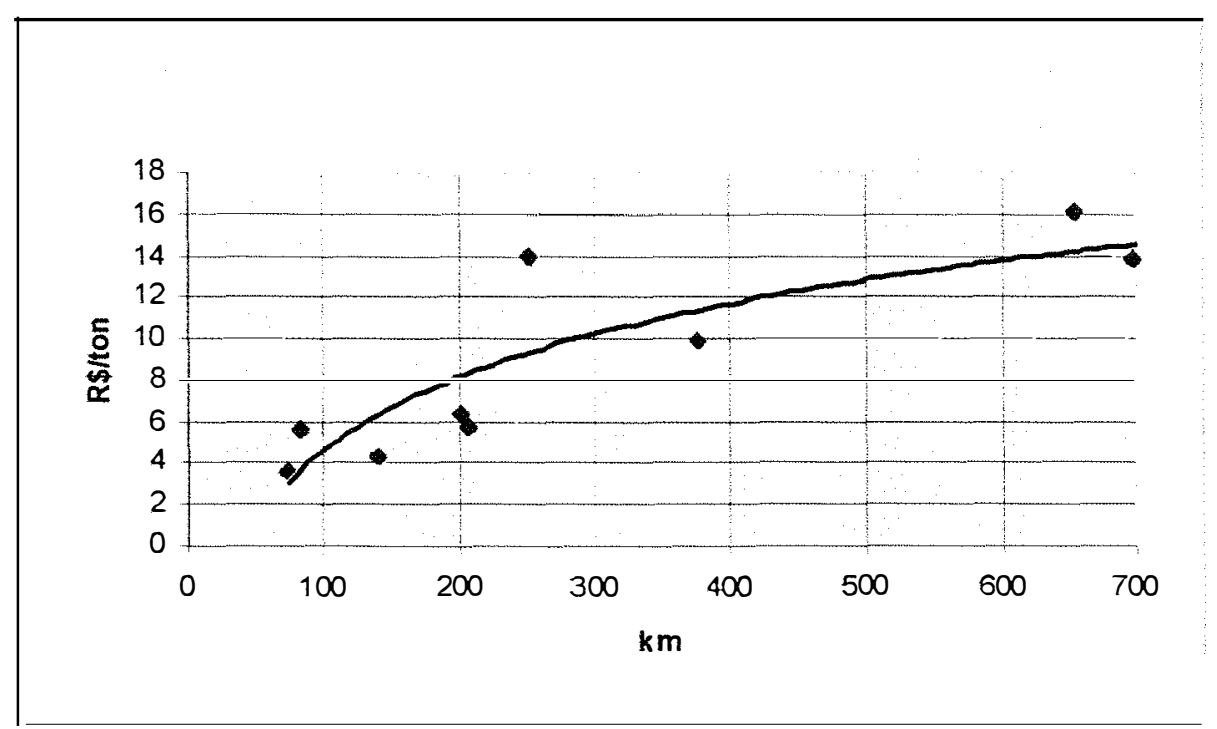

Figura 17 - Variação do Preço do Frete em Função da Distância. Fonte: Caixeta Filho (1996). 
Outro importante indicador da relevância da especificidade locacional, expresso pelo transporte, é a relaçào entre o volume e a distància de transporte. Como ilustrado na tabela abaixo, cerca de $65 \%$ do volume de madeira transportado para as fábricas de celulose provém de áreas localizadas num raio de até $100 \mathrm{~km}$ e 90,79\% do volume de madeira tem sua origem em até $200 \mathrm{~km}$ de distância das fábricas.

Tabela 19 -Volume de Madeira transportado das florestas e depósitos para as fábricas (1995).

\begin{tabular}{|c|c|c|}
\hline Distância (km) & Volume $\left.\mathbf{( m}^{\mathbf{3}}\right)$ & Participação (\%) \\
\hline \hline$<100$ & 30.228 .747 & 64,97 \\
$101-200$ & 12.015 .541 & 25,82 \\
$201-300$ & 2.955 .778 & 6,35 \\
$301-400$ & 704.487 & 1,51 \\
$401-500$ & 140.622 & 0,30 \\
$>501$ & 482.831 & 1,05 \\
\hline Total & 46.528 .007 & 100 \\
\hline
\end{tabular}

Fonte: ANFPC(1995) citado por Caixeta Filho (1996)

A terceira especificidade da madeira na produção de celulose é a especificidade do ativo físico. Cada processo industrial de polpeamento exige uma série de características físicoquímicas da madeira para seu perfeito funcionamento. A ausência destas caracteristicas pode inviabilizar a produção ou, no mínimo, reduzir o rendimento industrial.

Um exemplo de especificidade do ativo físico sào as características morfológicas das diferentes espécies. Nas espécies folhosas (gênero Eucaliptos), 90\% da lignina encontrase entre as fibras de madeira, enquanto nas espécies de coniferas, por exemplo do gênero Pinus, esta mesma substância localiza-se internamente às fibras. Além disso, as coniferas apresentam maior quantidade de lignina. Estas diferenças fazem com que os processos de polpeamento sejam distintos para um ou outro tipo de madeira (D’Almeida, 1988). 
O processo de polpeamento pode também ser diferenciado pela utilização de madeira verde ou seca. No segundo caso, a madeira deve passar por um processo de estocagem que varia de 30 a 120 dias, dependendo do local e da época do ano. Quando o processo industrial tem este tipo de exigência, se faz necessário o monitoramento do grau de secagem da madeira comprada de terceiros, o que não é um procedimento muito simples. Outra consequência da necessidade de secagem é que uma vez seca, a madeira tem seu uso ainda mais restrito ao processo de polpeamento originalmente planejado.

Outra exigência industrial, em termos de características da madeira, é o diâmetro das toras. Neste caso, a exigência é normalmente função das máquinas de descascamento e picagem da madeira. Esta característica torna a madeira um ativo específico porque o diâmetro demandado pode tornar a madeira inapta para a utilização em outros processos industriais.

Dentro do mesmo gênero, ou até da mesma espécie, podem ocorrer diferenças significativas na densidade da madeira em função das características do manejo (como idade de corte e espaçamento). Recentemente, a densidade da madeira tem sido foco de atenção das empresas produtoras de celulose. Acredita-se que o aumento da densidade da madeira pode estar fortemente correlacionado com ganhos de rendimento industrial. Se corroboradas as pesquisas neste sentido, há uma grande tendência de reformulação dos reflorestamentos, e, dependendo das espécies privilegiadas, há a possibilidade da madeira para a produção de celulose tornar-se ainda mais específica.

Assim como a indústria de papel e celulose, outras indústrias consumidoras de madeira também especificam características desejáveis na matéria-prima. Essencialmente em função da densidade da madeira, as espécies de rápido crescimento (E. grandis e $E$. saligna), utilizadas principalmente na produção de celulose, não são aceitas nos mercados de madeira para mourões, dormentes e carvão. Apesar dos mercados de construção 
civil $^{29}$ e serraria eventualmente consumirem madeira produzida para celulose, certamente não há uma fácil realocação do volume de madeira produzido, segundo a demanda das fábricas, para outros mercados que não o de celulose. Por outro lado, dado que apenas as fábricas de celulose demandam a madeira de certas espécies de eucalipto, fica estabelecida uma relação de dependência bilateral entre produtores de madeira e fábrica de celulose.

$\mathrm{Na}$ discussão acima, procurou-se mostrar a existência das especificidades de ativo dedicado, locacional e fisico, comparando o valor da madeira alocada na transação de abastecimento da fábrica de celulose com o valor desta mesma madeira em usos alternativos. No entanto, a análise foi desenvolvida de forma isolada para cada especificidade, ao passo que, na prática, todas elas ocorrem simultaneamente na matériaprima que chega à fábrica.

Cada uma das especificidades corresponde a características do ativo transacionado e, portanto, dizem respeito ao mesmo produto. Variando as especificidades de forma discreta é possivel caracterizar três destes produtos: i) madeira de eucalipto que atende a demanda de volume da fábrica (ativo dedicado), mas que não é específica em relação às suas características locacionais e físicas; ii) madeira de eucalipto que além de chegar em volume suficiente, tem origem em um raio economicamente interessante (ativo dedicado e locacional), mas não é específica em termos de suas características fisicas e iii) madeira de eucalipto que atende às restrições de volume e distància, mas também tem as melhores características fisico-químicas desejáveis (ativo dedicado, locacional e fisico).

Uma vez estabelecidos estes níveis discretos de especificidade, é possível imaginar uma graduação contínua, desde o produto madeira que sequer atende à demanda de volume da fábrica $\left(\mathrm{k}_{0}\right)$, até a madeira que atende totalmente as exigências de volume, distância e

\footnotetext{
${ }^{9}$ O mercado de construção civil utiliza esta madeira para a fabricação de pontaletes (peças de madeira de diâmetro em torno de $5 \mathrm{~cm}$ usadas para escorar as construções).
} 
qualidade $\left(k_{3}\right)$. Esta graduação continua corresponde a uma das dimensões necessárias para estabelecer a função que relaciona custos de transação e especificidade dos ativos.

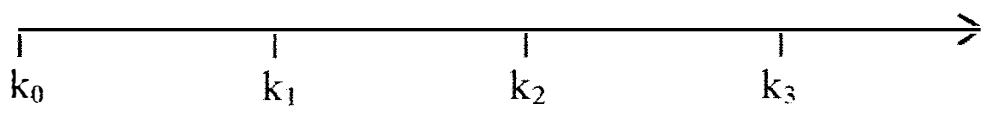

A caracterização da madeira associada a cada nível de especificidade é bastante clara, permitindo identificar qual é a contribuição, em termos de redução de custo, que cada produto oferece à empresa. A contribuição do aumento da especificidade da madeira pode ser identificada no preenchimento da tabela abaixo.

Tabela 20 - Estrutura de Cálculo da Especificidade da Madeira.

\begin{tabular}{|c|c|c|c|c|c|}
\hline $\begin{array}{c}\text { Nivel de } \\
\text { Especificidade }\end{array}$ & $\begin{array}{c}\text { Custo da } \\
\text { Madeira } \\
\text { Cortada }\end{array}$ & $\begin{array}{c}\text { Custo do } \\
\text { Frete } \\
\mathrm{F}_{2}<\mathrm{F}_{1}\end{array}$ & $\begin{array}{c}\text { Fator de } \\
\text { Conversão } \\
\mathrm{T}_{2}<\mathrm{T}_{1}\end{array}$ & $\begin{array}{c}\text { Custo da Madeira } \\
\text { na Celulose } \\
\mathrm{Y}_{3}<\mathrm{Y}_{2}<\mathrm{Y}_{1}\end{array}$ & $\begin{array}{c}\text { Valor da } \\
\text { especificidade (k) }\end{array}$ \\
\cline { 2 - 7 } & $(\mathrm{US} \$ / \mathrm{st})$ & $(\mathrm{US} \$ / \mathrm{st})$ & $($ st/ton cel $)$ & $(\mathrm{US} \$ /$ ton celulose $)$ & (kg celulose /US\$) \\
\hline \hline$(1)=$ Ativo Dedicado & $\mathrm{C}_{1}$ & $\mathrm{~F}_{1}$ & $\mathrm{~T}_{1}$ & $\mathrm{Y}_{1}=\left(\mathrm{C}_{1}+\mathrm{F}_{1}\right) \mathrm{T}_{1}$ & $\mathrm{k}_{1}=1000 / \mathrm{Y}_{1}$ \\
\hline$(2)=(1)+$ Locacional & $\mathrm{C}_{1}$ & $\mathrm{~F}_{2}$ & $\mathrm{~T}_{1}$ & $\mathrm{Y}_{2}=\left(\mathrm{C}_{1}+\mathrm{F}_{2}\right) \mathrm{T}_{1}$ & $\mathrm{k}_{2}=1000 / \mathrm{Y}_{2}$ \\
\hline$(3)=(2)+$ Físico & $\mathrm{C}_{1}$ & $\mathrm{~F}_{2}$ & $\mathrm{~T}_{2}$ & $\mathrm{Y}_{3}=\left(\mathrm{C}_{1}+\mathrm{F}_{2}\right) \mathrm{T}_{2}$ & $\mathrm{k}_{3}=1000 / \mathrm{Y}_{3}$ \\
\hline
\end{tabular}

$\mathrm{Na}$ tabela acima, a primeira coluna indica os diferentes níveis de especificidade da madeira utilizada na produção de celulose. Em (1) a madeira atende a especificidade de ativo dedicado. $\mathrm{O}$ valor deste produto é composto dos custos da madeira cortada $\left(\mathrm{C}_{1}\right)$, que inclui os custos diretos e indiretos para a implantação, manutenção e colheita das florestas, adicionado do custo do frete a uma distância máxima viável $\left(\mathrm{F}_{1}\right)$. Para estimar o custo da madeira na fabricação da celulose $\left(\mathrm{Y}_{1}\right)$, a soma destes custos $\left(\mathrm{C}_{1}+\mathrm{F}_{1}\right)$ é multiplicada por um fator máximo aceitável de conversão da madeira em celulose $\left(T_{1}\right)$. 
Em (2), a madeira transacionada apresenta, além da especificidade de ativo dedicado, a especificidade locacional. Este aumento da especificidade da madeira é expresso pela redução no custo do frete de $F_{1}$ para $F_{2}$, que correspondem, respectivamente, às distâncias maior e menor do raio de transporte praticado pela empresa.

Em (3) a madeira ganha a especificidade do ativo fisico. Neste caso, o produto passa a contribuir com uma qualidade tal que eleva o rendimento do processo industrial. Ao consumir este tipo de madeira a empresa produz mais celulose com menos madeira, reduzindo o fator de conversão de $T_{1}$ para $T_{2}$.

Os valores $C_{1}, F_{1}$ e $T_{1}$ pré-definem o nivel $k_{1}$ de especificidade minimo aceitável para a empresa. Ou seja, a madeira localizada fora do raio economicamente viável para a empresa (valor do frete maior que $F_{1}$ ), ou de espécies diferentes daquelas aceitas pelo processo industrial (fator de conversão maior que $T_{1}$ ), apresenta um nivel de especificidade abaixo do necessário para a empresa.

É importante verificar que a forma utilizada para estimação do valor da especificidade gera uma escala adequada de análise. A especificidade do produto tende a zero para custos da madeira muito elevados, e, no caso contrário, para custos muito pequenos, a especificidade do produto tende ao infinito.

O critério apresentado para a estimação da especificidade é também adequado para a análise do impacto dos incentivos fiscais ao reflorestamento. A legislação dos IFs permitia que recursos do IR fossem empregados nos projetos de reflorestamento, de tal forma que parte dos custos de produção da madeira fossem indiretamente pagos pelo governo. Esta redução de custos pode ser incorporada ao cálculo da especificidade retirando do valor total da madeira cortada as parcelas relativas à implantação e manutenção das florestas. 
Assim, a disponibilidade de incentivos fiscais promove um deslocamento das funções que relacionam especificidade e custo de transação. Tal deslocamento possibilita avaliar o impacto do fim dos incentivos sobre a escolha da estrutura de governança para a transação analisada.

É importante ressaltar que os incentivos foram oferecidos às pessoas jurídicas indistintamente, de forma que empresas de reflorestamento não integradas à empresa produtora de celulose poderiam ter utilizado o recurso fiscal para tornarem-se fornecedoras de madeira, à semelhança dos atuais fomentados. Em função deste fato é que foram estimadas funções tanto para a estrutura de governança hierárquica como para a contratual na condição de Incentivos Fiscais ao Reflorestamento.

A determinação dos níveis de especificidade do ativo define apenas uma das dimensões necessárias à determinação de uma função. Na sequência do trabalho, serão apresentados os critérios para estimação da segunda dimensão - os custos de transação associados ao abastecimento da fábrica de celulose.

\section{Custos de Transação}

Cheung (1990) ${ }^{30}$, citado por Azevedo (1996), apresenta os custos de transação como os custos de a) elaboração e negociação dos contratos, b) mensuração e fiscalização de direitos de propriedade, c) monitoramento do desempenho e d) organização das atividades. A estes custos Azevedo (1996) adiciona os custos de adaptações ineficientes às mudanças do sistema econômico.

As atividades descritas por Cheung (1990) e Azevedo (1996) são realizadas internamente nas empresas pelo conjunto de áreas administrativas, ocupadas basicamente de atividades

\footnotetext{
${ }^{30}$ CHEUNG. S. (1990) On the New Institutional Economics In: Cheung. S. et alii Contract Economics. +8-75p.
} 
burocráticas necessárias ao funcionamento adequado da empresa. No caso da empresa florestal, "funcionamento adequado da empresa" significa a garantia do abastecimento da fábrica de celulose com madeira que atenda às características pré-estabelecidas de volume, custo e qualidade. Assim, há dentro da estrutura burocrática da empresa diferentes áreas, não ligadas diretamente à produção, que tem como objetivo garantir cada uma das características (ou especificidades) da madeira entregue na fábrica.

O custo das áreas administrativas da empresa florestal está diretamente relacionado com a necessidade de garantir a realização da transação de abastecimento, com um produto que atenda à demanda de especificidades (ativo dedicado, locacional e fisico). Assim, os custos destas áreas podem ser utilizados como uma proxy dos custos de transação. É o que indica Azevedo (1996):

\begin{abstract}
"...basta observar os gastos internos em uma firma destinados ao controle e monitoramento das atividades de seus funcionários para se verificar a relevância dos custos de transação internos à firma. O salário de supervisores. cartões de ponto e auditorias são alguns exemplos que mostram a preocupação da firma - e que se traduzem em custo econômico - com a adequada execução de seus contratos internos. "
\end{abstract}

É importante salientar que a quantificação dos custos burocráticos internos da empresa não é exatamente igual à quantificação dos custos de transação, principalmente porque, no primeiro caso, não são captados os custos de adaptações ineficientes às mudanças do sistema econòmico. Outra limitação desta proxy é a eventual inclusão, nos custos burocráticos, de algum custo de transformação.

A classificação das áreas burocráticas da empresa foi feita a partir do orçamento anual da Divisão de Recursos Naturais, responsável pela produção de madeira e abastecimento da fábrica de celulose. No orçamento da DRN estão discriminados todos os custos de cada área (incluindo salários, honorários, despesas com material de escritório, viagens, cursos, consultoria externa e depreciação de bens materiais). 
Para a associação dos niveis de especificidade com as proxies dos custos de transação, foram identificados dois grupos de áreas burocraticas na DRN: o Grupo Suporte e o Especifico, como apresentado na Tabela 21. O Grupo Suporte é composto basicamente de áreas corporativas, cuja função não está diretamente relacionada com a garantia das especificidades da madeira no abastecimento da fábrica, mas que dão suporte para que o segundo grupo funcione. Já o Grupo Específico é composto pelas áreas especificamente encarregadas de garantir as características da madeira que chega à fábrica, porém num nivel administrativo.

\section{Tabela 21 - Áreas Burocráticas da DRN.}

\begin{tabular}{|l|l|}
\hline \multicolumn{1}{|c|}{ Grupo Suporte } & \multicolumn{1}{|c|}{ Grupo Especifico } \\
\hline Diretoria & Divisão Operacional Florestal \\
Assessoria Jurídica & Planejamento Florestal \\
Recursos Humanos & Inventário Florestal \\
Tesouraria & Controles Florestais \\
Contas a Pagar & Pesquisa Florestal \\
Contabilidade & Fomento Florestal \\
Registros Fiscais & \\
Patrimônio & \\
Gestão de Materiais & \\
Transportes & \\
\hline
\end{tabular}

Dentro do Grupo Especifico, foram identificadas as áreas responsáveis respectivamente pelos niveis de especificidade $k_{1}, k_{2}$ e $k_{3}$. A garantia do volume de abastecimento $\left(k_{1}\right)$ é função primordial da Divisão Operacional Florestal, bem como da área de Fomento Florestal, sendo a primeira responsável pelas áreas de produção própria e a segunda pela garantia da complementação do abastecimento com madeira produzida por terceiros (dentro do Programa de Fomento Florestal, previsto pela legislação).

A função da Divisão Operacional Florestal, como um todo, é o de garantir a produção de madeira para o abastecimento da fábrica de celulose. É importante ressaltar que os custos da área, utilizados na proxy dos custos de transação, incluem apenas aqueles referentes 
ao nivel gerencial. Assim, custos de transformação relativos às operações de implantação, manutenção e colheita, não estão incluidos nos custos de transação. É também interessante ressaltar que dentro da Divisão Operacional, o nível gerencial existe para coordenar a produção de madeira para o abastecimento da fábrica e, por isso, é uma estrutura burocrática típica da forma organizacional verticalizada. Assim, quando o abastecimento é administrado numa estrutura de governança do tipo contratual, a empresa apresenta, no lugar da Gerência da Divisão Operacional, uma área de "gestão de contratos", conhecida como a área de Fomento Florestal.

A garantia da localização estratégica das florestas a serem colhidas é conseguida com o trabalho conjunto das áreas já mencionadas (Div. Operacional e Fomento) e das áreas de Planejamento, Inventário e Controles Florestais. A passagem do nível de especificidade de $k_{1}$ para $k_{2}$ demanda um trabalho muito maior que a simples escolha de áreas para plantio ou fomento próximas à fábrica. A garantia do nível $\mathrm{k}_{2}$ depende do cadastramento, gerenciamento e controle das informações das áreas de produção, para a formação de um banco de dados que subsidie a análise detalhada das características destas áreas, a criação de modelos de previsão do volume de madeira a ser produzido e o planejamento da produção. As áreas de planejamento, inventário e controles são completamente desvinculadas da atividade produtiva, no que se refere ao processo de produção florestal, porém, como mencionado, delas depende o suporte informacional e estratégico. Por isso, o custos de funcionamento destas áreas devem ser considerados na estimação dos custos de transação.

O terceiro nivel de especificidade é conseguido com o trabalho de todas as áreas do Grupo Específico. O diferencial entre o nível $\mathrm{k}_{2} \mathrm{e}$ o nível $\mathrm{k}_{3}$ é dado pela área de pesquisa. Dela depende o direcionamento técnico da produção e o monitoramento da qualidade da madeira necessários para atingir o melhor rendimento no processo industrial de polpeamento. É nesse sentido que os custos de funcionamento da área de pesquisa devem ser compreendidos como custos de transação. Porém, não há como desvincular dos 
valores utilizados a parte referente à produção fisica de material genètico melhorado. Sendo esta, portanto, uma das fragilidades da estimação, mencionadas no início desta seção.

A apropriação dos custos de transação foi feita como indicado na tabela abaixo. Para cada nível de especificidade foram adicionados os custos referentes às áreas do Grupo Específico necessárias e uma parcela proporcional dos custos das áreas do Grupo Suporte.

Tabela 22 - Estimativas dos Custos de Transação (CT) em cada Nível de k.

\begin{tabular}{|l|c|c|c|}
\hline \multicolumn{1}{|c|}{ Áreas } & \multicolumn{2}{|c|}{ Nivel de Especificidade } \\
\hline Específicas & $\mathbf{k}_{1}$ & $\mathrm{k}_{2}$ & $\mathbf{k}_{3}$ \\
\hline \hline Div. Oper. & $\mathrm{A}$ & $\mathrm{A}$ & $\mathrm{A}$ \\
PIC & & $\mathrm{B}$ & $\mathrm{B}$ \\
Pesquisa & $\mathrm{D}$ & $\mathrm{D}$ & $\mathrm{C}$ \\
Fomento & $\mathrm{E}_{1}=\mathrm{A}+\mathrm{D}$ & $\mathrm{E}_{2}=\mathrm{A}+\mathrm{B}+\mathrm{D}$ & $\mathrm{E}_{3}=\mathrm{A}+\mathrm{B}+\mathrm{C}+\mathrm{D}$ \\
\hline Subtotal & $\mathrm{S}_{1}=\mathrm{S}\left(\mathrm{E}_{1} / \mathrm{E}_{3}\right)$ & $\mathrm{S}_{2}=\mathrm{S}\left(\mathrm{E}_{2} / \mathrm{E}_{3}\right)$ & $\mathrm{S}_{3}=\mathrm{S}$ \\
\hline Suporte & $\mathrm{CT}_{1}=\mathrm{E}_{1}+\mathrm{S}_{1}$ & $\mathrm{CT}_{2}=\mathrm{E}_{2}+\mathrm{S}_{2}$ & $\mathbf{C T}_{3}=\mathbf{E}_{3}+\mathrm{S}_{3}$ \\
\hline \multicolumn{1}{c|}{ Total } & & & \\
\hline
\end{tabular}

* S - custo total das áreas componentes do Grupo Suporte.

Segundo a teoria da ECT, os custos de transação elevam-se com o aumento do nível da especificidade dos ativos, porém de forma distinta, dependendo da estrutura de governança em que se dá a transação.

A cada estrutura de governança corresponde uma função que relaciona custos de transação e especificidade dos ativos. Apesar das estruturas de governança comporem um contínuo entre mercado e hierarquia, na análise estrutural discreta apenas as funções para algumas das estruturas são determinadas. As formas organizacionais alternativas para o 
abastecimento da fábrica de celulose estão restritas pela legislação florestal, como exposto na análise do ambiente institucional, à hierarquia ou aos contratos com produtores fomentados. Assim, foram estimadas funções para estas estruturas de governança em proporções variando de 0 a 100\%, com e sem a disponibilidade de incentivos fiscais ao reflorestamento.

Cada função estimada corresponde a um cenário diferente, como descrito na tabela abaixo:

Tabela 23 - Descrição dos cenários.

\begin{tabular}{|c|c|c|c|}
\hline $\begin{array}{c}\text { Cenários sem IFs } \\
\text { número }\end{array}$ & $\begin{array}{c}\text { Cenários com IFs } \\
\text { número }\end{array}$ & Hierarquia & Contrato \\
\hline 1 & 12 & 0 & 100 \\
\hline 2 & 13 & 10 & 90 \\
\hline 3 & 14 & 20 & 80 \\
\hline 4 & 15 & 30 & 70 \\
\hline 5 & 16 & 40 & 60 \\
\hline 6 & 17 & 50 & 50 \\
\hline 7 & 18 & 60 & 30 \\
\hline 8 & 19 & 70 & 20 \\
\hline 9 & 20 & 80 & 10 \\
\hline 10 & 21 & 90 & 0 \\
\hline 11 & 22 & 100 & 30 \\
\hline
\end{tabular}

Os custos utilizados como proxy dos custos de transação foram extraídos do orçamento de 1996, onde o custo mensal de cada área está discriminado. A apropriação dos custos para a estrutura de governança atual (Cenário 8) seguiu o formato apresentado na tabela 22. A diferenciação dos custos para as estruturas de governança dos demais cenários foi 
feita a partir dos custos apropriados para a estrutura atual, de acordo com os critérios apresentados a seguir.

Para compor os custos do Cenário 1 (100\% contratos), foram recalculados os custos das áreas do Grupo Específico. Inicialmente, foram eliminados os custos da Divisão Operacional Florestal, dado que a gestão da produção florestal passa, neste caso, para os produtores florestais desvinculados da empresa. Já os custos da área de Fomento, relativos à gestão da compra de madeira dos fomentados, foram ampliados proporcionalmente, ou seja, em $233 \%$. Isto porque, no Cenário 8 (atual), o fomento era responsável por $30 \%$ do abastecimento, enquanto no Cenário 1 passa a ser responsável por $100 \%$.

Os custos das áreas de planejamento, inventário e controles (PIC), foram "divididos" em duas partes. A primeira delas, estimada em $70 \%$, refere-se às atividades de planejamento e suporte informacional à produção de madeira e a segunda refere-se ao suporte à administração de contratos de compra de madeira. Na estrutura de governança 100\% contratual, as áreas de planejamento e suporte informacional foram mantidas integralmente. O fundamento desta manutenção é o de que, na ausência de áreas próprias a empresa deve manter um sistema de monitoramento das áreas de terceiros visando a garantia do abastecimento de madeira e a redução das quebras contratuais. A segunda parte do PIC foi ampliada proporcionalmente, no mesmo padrão da área de Fomento, por estar vinculada à administração de contratos de compra de madeira.

Os custos da área de Pesquisa foram mantidos constantes em todas as estruturas de governança. Isto porque hoje esta área já atende tanto às necessidades da produção própria como às dos fomentados (ainda que de forma menos intensiva no segundo caso). A manutenção dos custos de pesquisa constante entre as diferentes estruturas de governança também foi adotada em função da limitação desta proxy (inclusão de custos de transformação). 
que o risco de falta de matéria-prima para a fábrica (ou de demanda por madeira, pela ótica do produtor florestal) ocorre em função da ausência de mercados alternativos de compra e venda de madeira.

Esta análise preliminar sugere o teste da seguinte hipótese:

"A ausência dos incentivos fiscais ao reflorestamento eleva os custos de produção", estimulando a terceirização da base florestal. Porém, o aumento no custo de transação gerado pela escolha da estrutura contratual (dadas as características da transação) deve ser maior que a redução nos custos de produção conseguida com esta. Assim, mesmo na ausência dos incentivos fiscais ao reflorestamento, a estrutura predominantemente hierárquica deve manter-se."

Para uma melhor compreensão da hipótese, esta foi representada graficamente.

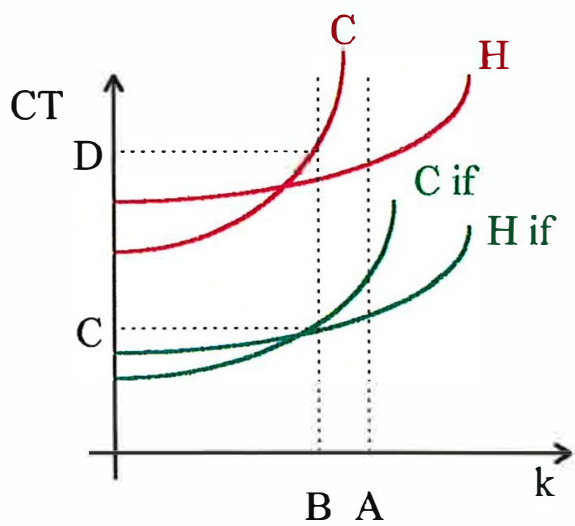

Situação 1

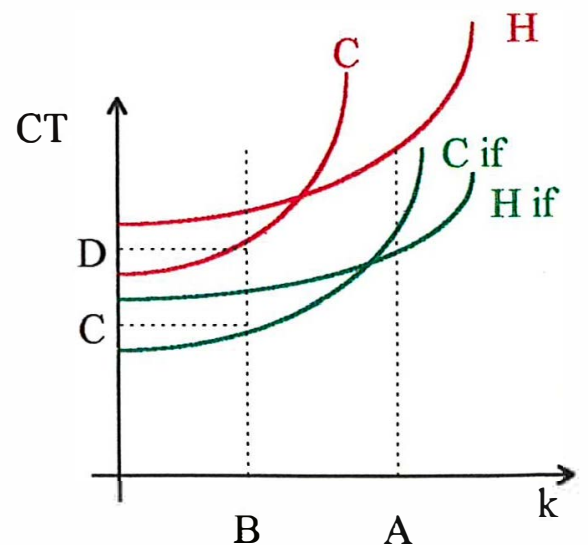

Situação 2

Figura 18 - Representação gráfica da hipótese.

\footnotetext{
${ }^{31}$ A rigor, os custos referidos aqui como custos de produção devem ser compreendidos como custos de transformação. Segundo Azevedo (1996) custos de produção são a soma dos custos de transação e de transformação, e esses últimos referem-se aos custos incorridos na transformação de fatores de produção em produto(s), desconsiderando-se a necessidade de adquirir-se tais fatores ou de vender tais produtos.
} 
A estimação dos custos de transação para o Cenário 11 (100\% hierárquica) seguiu os mesmos procedimentos descritos acima. A partir do Cenário 8 (atual), os custos da Divisão Operacional foram ampliados de 70 para 100\% do abastecimento, eliminaram-se os custos com a área de Fomento, enquanto os da área de Pesquisa foram mantidos constantes. Os custos das áreas do PIC relativos à administração de contratos foram eliminados, e os demais custos (referentes ao planejamento) foram ampliados proporcionalmente até corresponderem a $100 \%$ do abastecimento.

O critério de estimação de custos para os demais cenários foi o mesmo: ajustar a composição de custos a partir do Cenário 8 (atual). Assim, em cada caso os custos das áreas: Divisão Operacional, Fomento, PIC e Pesquisa foram ajustados proporcionalmente segundo a composição hierarquia x contrato do cenário em questão.

A partir das estimativas de custo e atributo da transação de abastecimento da fábrica de celulose, foram estimadas as funções que relacionam estas duas dimensões. $\mathrm{Na}$ seção seguinte, serão apresentadas as funções estimadas para cada estrutura de governança, bem como serão discutidas as estratégias de organização da empresa.

\subsection{Estruturas de Governança esperadas para o abastecimento}

Niveis elevados de especificidade do ativo madeira tendem a reduzir os custos de transação do abastecimento das fábricas de celulose quando integradas à sua base florestal. Isto porque os investimentos em ativos especificos aumentam a possibilidade de ocorrência de oportunismo, e estruturas hierárquicas de governança atenuam este comportamento em relação às transaçōes realizadas no mercado (Masten, 1994).

A forma integrada também é favorecida pela recorrência da transação, bem como pelo alto risco. Este último está diretamente relacionado à especificidade do ativo, uma vez 
Os gráficos acima mostram as funções que relacionam custos de transação (CT) e especificidade do ativo $(k)$ para as estruturas de governança hierárquica $(H)$ e contratual (C). As funções indicadas com "if" correspondem ao período de vigência dos incentivos fiscais ao reflorestamento. Variações nos custos de produção alteram de forma inversa o valor da especificidade do ativo, dada a sua definição ( $\mathrm{kg}$ cel./US\$). Assim, o aumento no custo de produção pode ser observado através da redução da especificidade.

Na situação 1 , o aumento dos custos de produção decorrente do fim dos IFs é menor que o aumento dos custos de transação da estrutura contratual $(A B<C D)$. Neste caso, apesar do aumento dos custos de produção favorecerem a estrutura contratual, a elevação dos custos de transação faz com que a estrutura hierárquica seja mais interessante. Já na situação 2, observa-se que o aumento dos custos de produção é tão elevado que torna proibitiva a manutenção da estrutura hierárquica $(\mathrm{AB}>\mathrm{CD})$.

A hipótese deste trabalho sugere que a situação 1 deve ocorrer para o estudo de caso desenvolvido.

O teste da hipótese apresentada foi realizado através da estimação das funções que relacionam atributos e custos de transação. As funções foram estimadas com base no modelo exponencial:

\section{$\ln C T_{G}=\ln a+k \ln b$}

Onde: $\mathrm{CT}_{\mathrm{G}}=$ custo de transação na estrutura de governança $\mathrm{G}$

$a$ e $b=$ parâmetros estimados para a função

$k=$ valor da especificidade

Os valores estimados para os parâmetros $a$ e $b$ estão apresentados nas tabelas 24 e 25 , para os cenários sem e com Incentivos Fiscais, respectivamente. 
Tabela 24 - Parâmetros das Funções para os cenários sem IFs.

\begin{tabular}{|c|c|c|c|c|c|}
\hline \multirow{2}{*}{$\begin{array}{l}\text { Cenários } \\
\text { sem IFs }\end{array}$} & \multicolumn{2}{|c|}{ Estrutura de Governança (\%) } & \multicolumn{2}{|c|}{ Parâmetros } & \multirow[t]{2}{*}{$\mathrm{R}^{2}$} \\
\hline & Hierarquia & Contrato & a & $\mathrm{b}$ & \\
\hline 1 & 0 & 100 & 0,000009 & 3,062400 & 0,999 \\
\hline 2 & 10 & 90 & 0,000025 & 2,775822 & 0,997 \\
\hline 3 & 20 & 80 & 0,000065 & 2,540628 & 0,995 \\
\hline 4 & 30 & 70 & 0,000158 & 2,344083 & 0,992 \\
\hline 5 & 40 & 60 & 0,000358 & 2,177344 & 0,987 \\
\hline 6 & 50 & 50 & 0,000767 & 2,034075 & 0,981 \\
\hline 7 & 60 & 40 & 0,001568 & 1,909613 & 0,974 \\
\hline 8 & 70 & 30 & 0,003077 & 1,800445 & 0,963 \\
\hline 9 & 80 & 20 & 0,005828 & 1,703875 & 0,950 \\
\hline 10 & 90 & 10 & 0,010700 & 1,617798 & 0,933 \\
\hline 11 & 100 & 0 & 0,019123 & 1,540545 & 0,911 \\
\hline
\end{tabular}

Tabela 25 - Parâmetros das Funções para os cenários com IFs.

\begin{tabular}{|c|c|c|c|c|c|}
\hline \multirow{2}{*}{$\begin{array}{l}\text { Cenários } \\
\text { com IFs }\end{array}$} & \multicolumn{2}{|c|}{ Estrutura de Governança (\%) } & \multicolumn{2}{|c|}{ Parâmetros } & \multirow[t]{2}{*}{$\mathrm{R}^{2}$} \\
\hline & Hierarquia & Contrato & a & $\mathrm{b}$ & \\
\hline 12 & 0 & 100 & 0,000018 & 2,652917 & 0,999 \\
\hline 13 & 10 & 90 & 0,000058 & 2,374154 & 0,999 \\
\hline 14 & 20 & 80 & 0,000164 & 2,156297 & 0,998 \\
\hline 15 & 30 & 70 & 0,000416 & 1.982039 & 0,996 \\
\hline 16 & 40 & 60 & 0,000966 & 1,839927 & 0,993 \\
\hline 17 & 50 & 50 & 0,002084 & 1.722104 & 0,988 \\
\hline 18 & 60 & 40 & 0,004225 & 1,623025 & 0,982 \\
\hline 19 & 70 & 30 & 0,008127 & 1,538668 & 0,975 \\
\hline 20 & 80 & 20 & 0,014943 & 1.466057 & 0,964 \\
\hline 21 & 90 & 10 & 0,026430 & 1,402944 & 0,950 \\
\hline 22 & 100 & 0 & 0,045201 & 1,347603 & 0,931 \\
\hline
\end{tabular}

Algumas das funções estimadas foram plotadas em dois gráficos representando, respectivamente, os cenários sem e com IFs. 


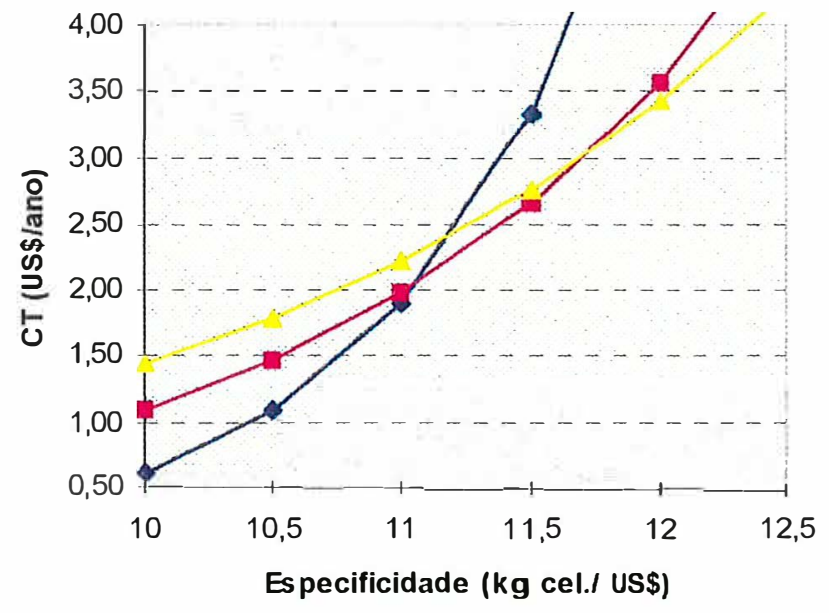

- $100 \%$ contrato

$\longrightarrow-30 \%$ contrato $100 \%$ hierarquia

Figura 19 - Estruturas de Governança (sem IFs).

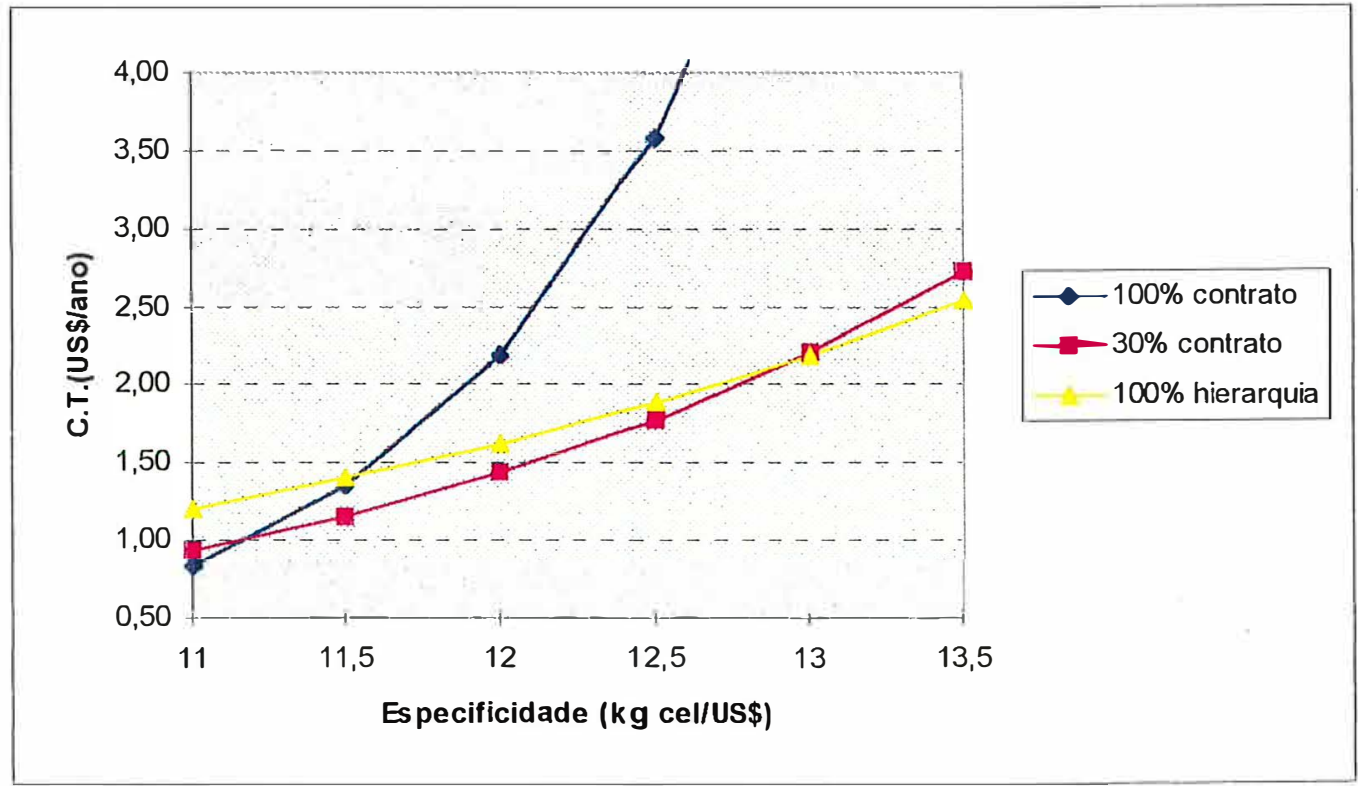

Figura 20 - Estruturas de Governança (com IFs) 
Observa-se que, em ambos os gráficos, o padrão de comportamento das curvas é o mesmo e totalmente coerente com a teoria da ECT (Figura 10, página 55). Quanto maior a especificidade do ativo maiores são os custos de transação de todas as estruturas de governança, em especial das estruturas contratuais. Para níveis de especificidade baixos as estruturas de governança contratuais tendem a apresentar menor custo de transação que em níveis de especificidade mais elevados. Neste último caso, estruturas de governança do tipo hierárquica passam a ser mais interessantes.

Para uma análise inicial do efeito do fim dos incentivos fiscais ao reflorestamento sobre as estruturas de governança, analisaremos as funçòes apresentadas nas Figuras 19 e 20. Nestas figuras estão apresentadas alternativas teóricas de organização da empresa. Na realidade, nunca existiu uma estrutura $100 \%$ contratual, nem mesmo 100\% hierárquica, mas estes eram, em tese, os caminhos extremos que poderiam ser seguidos pela empresa. A análise da legislação florestal foi suficiente para demonstrar a existência destas alternativas, mas não foi capaz de justificar porque apenas a estrutura predominantemente hierárquica se estabeleceu.

Considerando os atuais custos de produção de celulose de diversos países, apresentados no primeiro capítulo deste trabalho, um custo altamente competitivo equivale a US\$215 por tonelada de celulose. Considerando-se, ainda, que cerca de $40 \%$ deste valor corresponde à produção da madeira, a especificidade desta matéria-prima é de $11,6^{32} \mathrm{~kg}$ cel./US\$. Este valor de especificidade será utilizado como referência para a escolha da estrutura de governança numa situação em que não vigoram os IFs.

Durante a vigência dos IFs, no entanto, o custo de produção da celulose era menor. Em outras palavras, produziam-se mais quilos de celulose por unidade de dólar investido. Assim, no periodo de vigência dos IFs a especificidade da madeira, da forma como foi definida neste trabalho, era maior. Este aumento no valor da especificidade gerado pela 
redução nos custos de implantação e manutenção das florestas foi calculado em $16 \%$, de forma que o nivel de especificidade utilizado para a análise do periodo dos IFs foi de 13,4 $\mathrm{kg}$ cel./US\$.

De acordo com a Figura 20, para a firma operar a um nivel de especificidade de $13,4 \mathrm{~kg}$ cel./US\$, a estrutura hierárquica, já na época dos incentivos fiscais, seria recomendada por apresentar menor custo de transação, comparativamente à estrutura de governança contratual. Complementarmente, as características de frequência e incerteza da transação são fatores que reforçam a justificativa do processo de verticalização da empresa.

De fato, houve um nítido investimento por parte da empresa para garantir $100 \%$ de autoabastecimento, embora este nunca tenha sido atingido. No entanto, cerca de sete anos após o fim dos incentivos, em 1993, a composição do abastecimento da fábrica passou a sofrer alterações gradativas. O volume de madeira comprado dos fomentados aumentou entre os anos de 1993 a 1996, indicando uma tendência de reorganização da estrutura de governança.

Tabela 26 - Abastecimento com Madeira Própria e do Fomento (93 a 96)

\begin{tabular}{|c|c|c|}
\hline Ano & Madeira Própria (\%) & Madeira Fomento (\%) \\
\hline \hline 1993 & 89,01 & 10,99 \\
1994 & 82,63 & 17,37 \\
1995 & 76,97 & 23,03 \\
1996 & 72,48 & 27,52 \\
\hline
\end{tabular}

Considerando que o tempo necessário para o desenvolvimento das florestas utilizadas pela empresa é em média de sete anos, evidencia-se que as alterações no abastecimento da fábrica apresentadas entre 1993 e 1996 são resultantes de modificações nos plantios

\footnotetext{
${ }^{32}$ De acordo com as fórmulas da Tabela 20, para $\mathrm{Y}=(215 * 0.40): \mathrm{k}=1000 /\left(215^{*} 0.40\right)=11.627907$
} 
realizados a partir de 1986. O fim dos incentivos fiscais ao reflorestamento data justamente deste periodo ${ }^{33}$.

Há, portanto, uma forte evidència de que as alterações na estrutura de governança apresentadas acima tenham sua origem na mudança institucional do fim dos incentivos fiscais ao reflorestamento. Resta ainda analisar até onde tal mudança institucional deve impactar sobre a estrutura de governança utilizada.

A Figura 19, comparativamente à Figura 20, mostra que o fim dos IFs resultou numa elevação dos custos de transação para todas as estruturas de governança. A Figura 19 indica, ainda, que para o nivel de especificidade de $11,6 \mathrm{~kg}$ cel./US\$ há estruturas de governança de menor custo que a 100\% hierárquica. Através das funções estimadas é possivel calcular com exatidão quais são estas estruturas, ou ainda, determinar o nível de especificidade a partir do qual cada estrutura de governança passa a ser a mais interessante para a empresa ${ }^{34}$.

Em termos genéricos, o valor da especificidade que iguala o custo de transação de duas estruturas de governança é dado pela seguinte expressão:

$$
k=\left(\log a_{j}-\log a_{i}\right) /\left(\log b_{i}-\log b_{j}\right)
$$

Onde: $\mathrm{k}=$ especificidade do ativo

$$
\begin{aligned}
& a_{i} ; a_{j}=\text { parâmetros "a" estimados para os cenários i e j } \\
& b_{i} ; b_{j}=\text { parâmetros " } b \text { " estimados para os cenários } i \text { e } j \\
& i=[1, \ldots, 21] \\
& j=i+1
\end{aligned}
$$

\footnotetext{
${ }^{33}$ A rigor o fim dos IFs ocorreu em 1988. porém. já em 1986 os recursos disponíveis para reflorestamento eram mínimos.

${ }^{34}$ A determinação da estrutura de governança de menor custo de transação está obviamente restrita às onze estruturas simuladas neste trabalho.
} 
Utilizando-se a expressão acima foi possivel calcular, para cada intervalo de especificidade, a estrutura de governança de menor custo de transação.

Tabela 27 - Estruturas de governança de menor C.T. por nível de k, com e sem IFs.

\begin{tabular}{|c|c|c|c|c|}
\hline \multirow{2}{*}{$\begin{array}{l}\text { Especificidade } \\
\mathrm{k} \text { (kg cel./US\$) }\end{array}$} & \multicolumn{2}{|c|}{ Estrutura de Govemança (sem IFs) } & \multicolumn{2}{|c|}{ Estrutura de Govemança (com IFs) } \\
\hline & $\mathrm{H}(\%)$ & $\mathrm{C}(\%)$ & $\mathrm{H}(\%)$ & $\mathrm{C}(\%)$ \\
\hline$<10.5$ & 0 & 100 & 0 & 100 \\
\hline $10.5-10.7$ & 0 & 100 & 10 & 90 \\
\hline $10.7-10.8$ & 0 & 100 & 20 & 80 \\
\hline $10.8-10.9$ & 10 & 90 & 20 & 80 \\
\hline $10.9-11.0$ & 20 & 80 & 20 & 80 \\
\hline $11.0-11.1$ & 30 & 70 & 30 & 70 \\
\hline $11.1-11.2$ & 40 & 60 & 30 & 70 \\
\hline $11.2-11.3$ & 50 & 50 & 30 & 70 \\
\hline $11.3-11.4$ & 60 & 40 & 40 & 60 \\
\hline $11.4-11.6$ & 70 & 30 & 40 & 60 \\
\hline $11.6-11.7$ & 80 & 20 & 50 & 50 \\
\hline $11.7-11.9$ & 90 & 10 & 50 & 50 \\
\hline $11.9-12.2$ & 100 & 0 & 60 & 40 \\
\hline $12.2-12.6$ & 100 & 0 & 70 & 30 \\
\hline $12.6-12.9$ & 100 & 0 & 80 & 20 \\
\hline $12.9-13.3$ & 100 & 0 & 90 & 10 \\
\hline$>13.3$ & 100 & 0 & 100 & 0 \\
\hline
\end{tabular}

A Tabela 27 demonstra que na presença de IFs e para o nível de especificidade de 13,4 $\mathrm{kg}$ cel./US\$ a estrutura de governança 100\% hierárquica representa a alternativa de 
Esta variação nos custos de produção, equivalente a $1,8 \mathrm{~kg}$ cel./US\$, favorece a adoção da estrutura contratual. Isto é evidenciado nas funções representadas com linhas tracejadas na Figura 21. A variação da especificidade de 13,4 para $11,6 \mathrm{~kg}$ cel./US\$ faz com que a estrutura contratual deixe de ser inviável para tornar-se uma alternativa factivel no que se refere a custos de transação.

No entanto, na ausência dos IFs, o nivel de especificidade é de 11,6 e as funções são as representadas por linhas contínuas. Assim, o custo de transação associado à estrutura contratual passa de 1,49 para 3,73 US\$/ano. O aumento de 2,24 US\$/ano no custo de transação associado à estrutura contratual faz da estrutura hierárquica uma alternativa de menor custo de transação, e portanto, mais interessante para a empresa.

Como indicado na Figura 18 e na Tabela 27, para o nível de especificidade estabelecido como meta para a empresa, as estruturas de governança predominantemente contratuais são alternativas inviáveis do ponto de vista de custos de transação. No entanto, outras estruturas compostas em sua maioria pela hierarquia têm um desempenho semelhante entre si. Assim, pequenas variações na composição do abastecimento são esperadas em reação à mudança na legislação, porém não estão previstas alterações que levem, por exemplo, à terceirização completa da base florestal. 
menor custo de transação. Constata-se que a empresa procurou adequar de forma correta sua estrutura de governança ao ambiente institucional onde vigoravam incentivos fiscais ao reflorestamento.

Da mesma forma que a empresa parece ter ajustado sua estrutura de governança adequadamente no período dos IFs, a estrutura escolhida posteriormente também mostrou-se coerente. Com o fim dos IFs, para o nível de especificidade de $11,6 \mathrm{~kg}$ cel./US\$ a estrutura de governança de menor custo de transação é formada $80 \%$ pela hierarquia e $20 \%$ pelos contratos, como demonstrado na Tabela 27.

Além disso, através da Tabela 27 corrobora-se a hipótese de que mesmo na ausência dos incentivos fiscais ao reflorestamento a estrutura predominantemente verticalizada deverá manter-se, por ser mais atraente do ponto de vista de custos de transação.

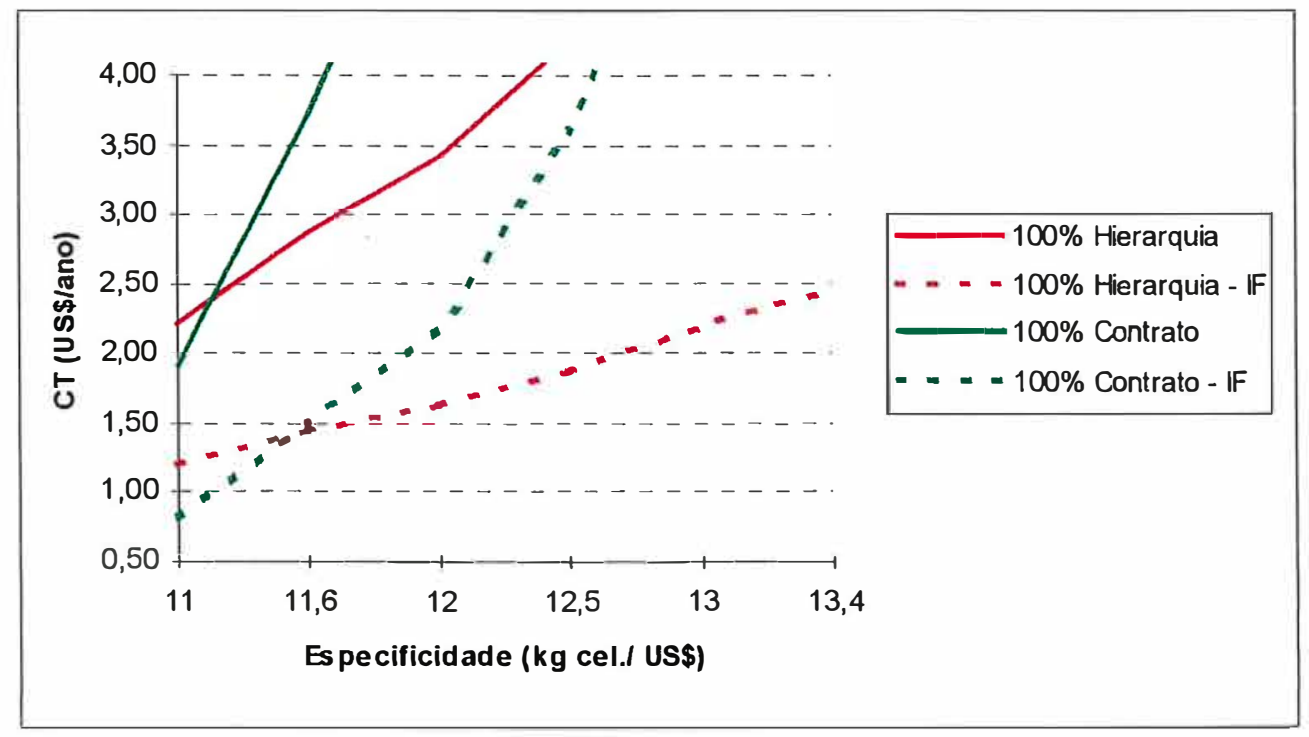

Figura 21 - Efeito do fim dos IFs sobre as estruturas de governança.

Comparando-se a Figura 18 com a Figura 21 observa-se graficamente porque a hipótese deste trabalho foi corroborada. O aumento nos custos de produção gerado a partir do término dos IFs determinou a redução da especificidade de 13,4 para 11,6 kg cel./US\$. 


\section{Considerações Finais}

Neste trabalho foram utilizados os conceitos da ECT para análise da transação de abastecimento de madeira nas fábricas de celulose em dois momentos da história. Tais momentos, caracterizados por diferentes ambientes institucionais, são: o período de estabelecimento da indústria de celulose no país e o momento atual, em que não mais vigoram os Incentivos Fiscais ao Reflorestamento (IFs) e a abertura do mercado nacional internacionalizou a concorrência entre as empresas.

De forma bastante objetiva, o fim dos incentivos fiscais representa um aumento de custo, uma vez que o Estado arcava com os principais custos da produção florestal (implantação e manutenção dos plantios). Esta elevação de custos da atividade florestal ocorre no momento em que a pressão por competitividade, compreendida como eficiência sustentada no longo prazo, transcende o limite das empresas e atinge todo o sistema agroindustrial (SAG).

Particularmente neste trabalho, em que a questão central de discussão é uma mudança institucional que pode mudar a estrutura organizacional vigente para uma estrutura jamais observada empiricamente, não há como fazer uso de modelos econométricos tradicionais. A opção encontrada foi buscar uma forma de estimar as funções que relacionam custos e atributos da transação, ainda que os valores utilizados sejam estimativas, na tentativa de evidenciar o efeito da mudança institucional em questão.

O modelo proposto neste trabalho para a análise do impacto do fim dos IFs sobre a escolha de estruturas de governança mostrou-se adequado ao seu propósito. A partir deste modelo foram gerados resultados coerentes com a teoria da ECT, bem como com a realidade. 
Os resultados encontrados demonstram que a empresa escolheu as estruturas de governança mais adequadas tanto no período de vigência dos Incentivos Fiscais ao Reflorestamento como ao final deste. Se por um lado, era interessante buscar uma estrutura $100 \%$ hierárquica enquanto havia IFs, hoje, as estruturas de menor custo de transação são compostas $80 \%$ pela hierarquia e $20 \%$ pelos contratos.

Outras estruturas compostas em sua maioria pela hierarquia têm um desempenho semelhante entre si. Assim, pequenas variações na composição do abastecimento são esperadas em reação à mudança na legislação, porém não estão previstas alterações que levem, por exemplo, à terceirização completa da base florestal. Este resultado corrobora a hipótese do trabalho de que mesmo com o fim dos IFs a estrutura de governança de menor custo de transação seria predominantemente hierárquica.

Em termos teóricos, o modelo mostra uma forma simples e coerente com os conceitos da Economia dos Custos de Transação para quantificar atributos e custos de transação. Desta forma, o resultado deste trabalho contribui de maneira efetiva na solução daquele que é reconhecido atualmente como o principal problema da ECT. Trata-se de um modelo específico, baseado em informações de uma única empresa, e que pode ser estendido para outras empresas deste ou de outros SAGs.

A capacidade de realizar prognósticos é outro ponto forte do modelo. É importante salientar, no entanto, que esta capacidade fica restrita a dado momento, uma vez que todo o modelo baseia-se em valores de custo.

É interessante ressaltar que não há restrições à utilização do conceito proposto neste trabalho para estimação dos custos de transação em outros trabalhos. No entanto, para gerar cenários diferentes, especialmente aqueles que envolvam estruturas de governança não observadas empiricamente, é preferivel que a empresa adote tanto a forma contratual como a hierárquica em sua estrutura organizacional atual. 
Quanto à utilização direta do modelo de cálculo da especificidade em outros trabalhos é necessário observar algumas restrições. Em primeiro lugar, o cálculo da especificidade foi estruturado para uma transação de abastecimento com matéria-prima. Eventualmente, em outros tipos de transação a estrutura de cálculo pode não se mostrar adequada. Outra restrição é a ocorrência dos mesmos tipos de especificidade do ativo (de ativo dedicado, locacional e fisica).

Apesar da eventual necessidade de alguns ajustes na forma de calcular o valor da especificidade em outros trabalhos, a definição de especificidade como: "quantidade de produto/ unidade de moeda investida" é válida em função do conceito fundamental de perda do valor do ativo em utilizações alternativas àquela em que o ativo é específico.

Sugere-se para os trabalhos futuros a continuidade da utilização da Economia dos Custos de Transação. Tal teoria oferece um ferramental bastante rico para a análise da questão organizacional, permitindo a interpretação dos fatos sob uma ótica realista e consistente com o comportamento das empresas. O desenvolvimento de trabalhos empíricos baseados nos conceitos da ECT e com um cunho quantitativo atendem à principal demanda atual de avanço da teoria, bem como auxilia as empresas na tomada de decisão. 
BIBLIOGRAFIA

ANFPC - Associação Nacional dos Fabricantes de Papel e Celulose. A política de Desenvolvimento do Complexo Celulose - Papel: 1995-2005 Sào Paulo, Ago 1995. 5lp.

ANFPC - Associação Nacional dos Fabricantes de Papel e Celulose Relatório Estatístico - 1995 Sào Paulo, 1996.

ANFPC - Associação Nacional dos Fabricantes de Papel e Celulose Relatório Estatístico - 1993 Sào Paulo, 1994

ANFPC - Associação Nacional dos Fabricantes de Papel e Celulose Relatório Estatístico - 1991 São Paulo, 1992

AZEVEDO, P.F. Integraçào Vertical e Barganha. Sào Paulo, 1996. 219p. Tese (Doutorado) Faculdade de Economia e Administração, Universidade de São Paulo.

BACHA, C.J.C. A Dinâmica do Desmatamento e Reflorestamento no Brasil. Piracicaba, 1993. 236p. Tese (Livre Docência) - Escola Superior de Agricultura "Luiz de Queiroz", Universidade de São Paulo.

BOEHLJE, M.; AKRIDGE, J.: DOWNEY, D. Reestructuring Agribusiness for the 21 st century. Agribusiness - An International Journal, v.11, n.6, p.493-500, 1995.

BUENO. M. Papel e Celulose - espaço para crescer. Agroanalysis, Jun., 8-1 lp., 1996.

C\&P - Celulose e Papel. Ano XIII n.52 28-31 p., 1996.

CAIXETA FILHO, J.V. Mercado de Fretes e Roteamento de Cargas Florestais. Material de apoio ao curso ministrado no II Programa de Reciclagem em Métodos Quantitativos IPEF Piracicaba, 1996.

COASE, R.H. The Nature of the Firm. Economica, n.4, 386-405p., 1937.

D'ALMEIDA, M.L.O. Composição Química dos Materiais Lignocelulósicos. In: D'ALMEIDA, M.L.O. Celulose e Papel Tecnologia da Fabricação da Pasta Celulósica. São Paulo: IPT, 1988. Cap.3, 559p.

DAVIS, J.H.: GOLBERG, R.A. A Concept of Agribusiness. Harvard University, Boston, 135 p., 1957.

FAO Yearbook - Forest Products. Italy, Rome, 1994. 
FARINA, E.M.M.Q; ZYLBERSZTAJN, D. Agribusiness: Coordenação das Relações de Conflito e Cooperação. Programa de Estudo dos Negócios do Sistema Agroindustrial PENSA São Paulo: FEA/USP, 1993. 28p.

FARINA, E.M.M.Q;; ZYLBERSZTAJN, D. Competitividade e Organização das Cadeias Agroindustriais. Capitulo 3: Coordenação e Competitividade no Agribusiness. IICA, 1994. No prelo.

GAZETA MERCANTIL. Gazeta Mercantil Latino Americana - Seminário do Mercosul. Ano l, n.5, 06 a 12 de Maio, 1996. 32 p.

GLOBERMAN, S.; SCHWINDT, R. The Organization of Vertically Related Transactions in the Canadian Forest Products Industries. Journal of Economic Behavior \& Organization, v.7, n.2, 199-212 p., Jun 1986.

GOLDBERG, R.A. Agribusiness Coordination. Harvard University, 1968. 256p.

HOFFMANN, R. Estatística para Economistas. 2a ed. São Paulo: Ed. Pioneira, 1991. 426p.

IBGE Fundação Instituto Brasileiro de Geografia e Estatística - Anuário Estatístico do Brasil. Brasil, Rio de janeiro, 1995.

JANK, M.S. Competitividade no Agribusiness Brasileiro: Discussão Teórica e Evidências no Sistema Cames. São Paulo, 1996. 195p. Tese (Doutorado) - Faculdade de Economia e Administração, Universidade de São Paulo.

JOHANSSON, L. Asia keeps up the pace. Pulp and Paper International, v.38, n.4, 25-27p., Apr 1996.

JOSKOW, P.L. The New Institutional Economics: Alternative Approaches. Journal of Institutional and Theoretical Economics, v.151, n. 1, p.248-59, 1995.

KOGA, M.E.T. Matérias Primas Fibrosas. In: D’Almeida, M.L.O. Celulose e Papel Tecnologia de Fabricação da Pasta Celulósica. Vol. 1 2a ed. São Paulo: IPT, 1988. Cap.2, p. 15-40.

KREPS, D.M. A Course in Microeconomic Theory. USA: Ed. HarvesterWheatsheaf, 1990. $839 \mathrm{p}$.

LARSON, E.D.; RODRIGUEZ,L.C.E.; AZEVEDO, T.R. Farm Forestry in Brazil. Apresentado ao BioResources '94 Biomass Resources: a means to sustainable development, Bangalore, India, Oct. 3-7, 1994.

LIEBERMAN, M.B. Determinants of Vertical Integration: an Empirical Test. The Journal of Industrial Economics, v.39, n.5, p. 451-65, Set 1991. 
MACEDO, A.R.P.; MATTOS, R.L.G. A Trajetoria de Crescimento dos Principais Produtores Brasileiros de Papel e Celulose - 1970/94 Revista BNDES Setorial, n.3, 49-72p., Mar 1996.

MACEDO, A.R.P.; VALENÇA, A.C.V. A Indústria de Papel no Brasil e no Mundo: Uma visão geral. Revista BNDES Setorial, 151-62 p., 1995.

MAHONEY, J.T.; CRANK, D.A.; LAJILI, K. Spot Markets, Vertical Contracting and Vertical Financial Ownership: Competition Among Organizational Forms. Apresentado à conferência Interactions between Public Policies and Private Strategies in the Food Industries, Montreal, Canadá, June 26-28, 1994.

MASTEN, S.E. Empirical Research in Transaction Cost Economics: Challenges, Progress, Directions. Versão preliminar preparada para Conference on TCE and Beyond Rotterdam, Jun 1994. 27p.

MATUSSEK, H.; PAPPENS, R.; BRENNAN, W. Top 150 Listing - Huge Rise In Profits For Pulp \& Papermakers. Pulp And Paper International - PPI, v.37, n.9, p.33-47, Set 1995.

MURIS, T.J.; SCHEFFMAN, D.T.; SPILlER, P.T. Strategy and Transaction Costs: The Organization of Distribution in the Carbonated Soft Drink Industry. Journal of Economics \& Management Strategy, v. 1, n.1, 83-128p., Spring

MURRAY, B.C. Oligopsony, vertical integration and output substitution: Welfare effects in U.S. pulpwood markets. Land Economics, v.71, n.2, 193-206 p., Mai 1995.

NEVES, M. F. Sistema Agroindustrial Citricola: um exemplo de quase-integração no agribusiness brasileiro. São Paulo, 1995. 116p. Dissertação (Mestrado) - Faculdade de Economia e Administração, Universidade de São Paulo.

NORTH, D.C. Custos de Transação, Instituições e Desempenho Econômico. Série Ensaios Técnicos \& Artigos. Rio de Janeiro: Ed. Instituto Liberal 1992.

OHANIAN, N.K. Vertical Integration in the U.S. pulp and paper industry, 1900-1940 Review of Economics \& Statistics, v.76, n.1, 202-7p., Feb. 1994.

PPI - PULP AND PAPER INTERNATIONAL. Anual Review, 37v. 7n., Jul 1995.

PPI - PULP AND PAPER INTERNATIONAL. Anual Review, 38v. 7n., Jul 1996.

RESENDE, M. Medidas de Concentração Industrial: Uma Resenha. Análise Econômica, Ano 12 n.21 e 22, p.24-33, Mar/Set 1994.

RIORDAN, M.H.; WILLIAMSON, O.E. Asset Specificity and Economic Organization. International Journal of Industrial Organization, n.j. p.365-78, 1985. 
SHELMAN, M.L. The Agribusiness System Approach - Cases and Concepts. Proceedings of The International Agribusiness Management Association, 5p., Mar 1991.

STREETER, D.H.; SONKA, S.T.; HUDSON, S.T. Information Technology, Coordination and Competitiveness in the Food and Agribusiness Sector. American Journal of Agricultural Economics, v.73, n.05, p.1465-71, Dec. 1991.

SWIOKLO, M.T.; WILLADINO, P.H.V. Florestas Plantadas Incentivadas: Implicações e Vínculos. São Paulo, 1996. Não publicado.

WILIAMSON, O.E. The Economic Institutions of Capitalism. London: The Free Press, 1985. $450 \mathrm{p}$.

WILIAMSON, O.E. Comparative Economic Organization: The Analysis of Discrete Structural Altematives. Administrative Science Quarterly, v.36, p. 269-96, Jun. 1991 la.

WILIAMSON, O.E. Strategizing, Economizing and Economic Organization. Strategic Management Journal, v.12, p.75-94, 1991 b.

WILIAMSON, O.E. Transaction Cost Economics and Organization Theory. Industrial and Corporate Change, v.2, p. 107-56, 1993.

WILIAMSON, O.E. The Mecanisms of Govemance: Prologue. Berkeley: University of Califomia, Nov. 1994. 33p.

ZYLBERSZTAJN, D. Estruturas de Govemança e Coordenação do Agribusiness: Uma Aplicação da Nova Economia das Instituições. São Paulo, 1995. 238p. Tese (Livre Docência) - Faculdade de Economia e Administração, Universidade de São Paulo. 